


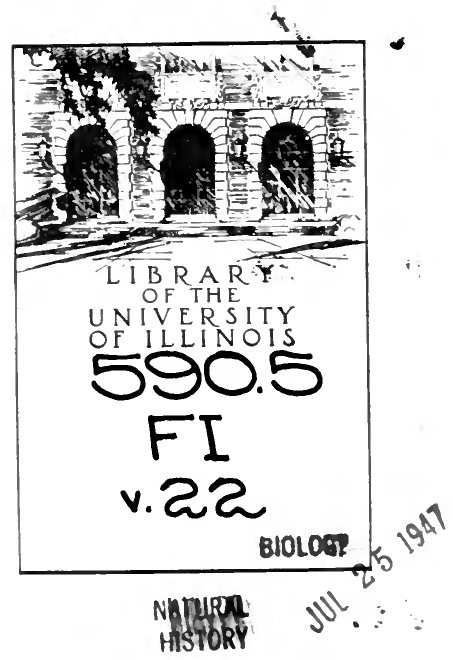


Return this book on or before the Latest Date stamped below. A charge is made on all overdue books.

University of Illinois Library

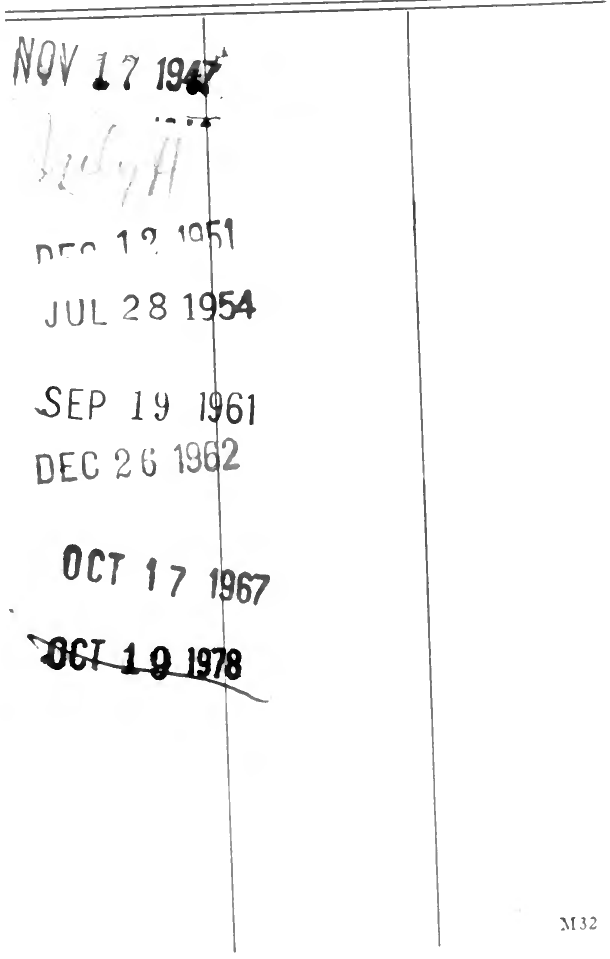






\title{
A NEW CATALOGUE \\ OF THE \\ FRESH-WATER FISHES OF PANAMA
}

BY

\author{
SAMUEL F. HILDEBRAND \\ SENIOR ICHTHYOLOGIST \\ UNITED STATES BURFAU OF FISHERIES
}

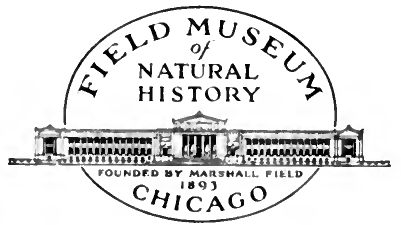

THE LIBRARY OF THE

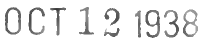

UNIVERSITY OF ILLINOIS

ZOOLOGICAL SERIES

FIELD MUSEUM OF NATURAL HISTORY

VOLUME XXII, NUMBER 4

SEPTEMBER 28, 1938

PUBLICATION 425 
PRINTED IN THE UNITED STATES OF AMERICA BY FIELD MUSEUM PRESS 


\section{CONTENTS}

Notes on the Origin and Distribution of Panama Fishes . . 221 Introduction of Fishes . . . . . . . . . . . . . . . . . 225

New and Abandoned Localities . . . . . . . . . . . . 228

Acknowledgments . . . . . . . . . . . . . . . . . . . 230

New Species Described . . . . . . . . . . . . . . . . . 231

Catalogue of Species . . . . . . . . . . . . . . 231

References . . . . . . . . . . . . . . . 357 



\section{A NEW CATALOGUE OF THE FRESH-WATER FISHES OF PANAMA ${ }^{1}$}

BY SAMUEL F. HILDEBRAND

\section{INTRODUCTION}

The present paper embodies the results of a study based mainly on specimens and data collected by the writer in 1935 and 1937. This study was supplemented by information gained from the examination of small collections made by others. Furthermore, some of the material collected in 1911 and 1912 by the late Dr. Seth E. Meek and the writer, was re-examined for further information.

The Fishes of the Fresh Waters of Panama by Seth E. Meek and the writer, published by Field Museum in 1916, has been drawn upon freely. The present paper is intended to supplement this earlier general work. Errors in that publication have been pointed out, descriptions have been emended if necessary, and in some instances new keys have been given to include species since recorded. All the species described in the earlier work are mentioned in the present one, together with such additional information as seems worthy of record, including the up-to-date knowledge of distribution. Descriptions, or at least sufficient information for identification of species not included in the general account of 1916 , are given in the present paper. In the synonymy only the names used by the original describers are given, together with a reference to our earlier general work; if not included therein a reference to other writers who have recorded the species from Panama is included.

The principal papers on fresh-water fishes of Panama, that have appeared since 1916 are The Fishes of the Rio Chucunaque Drainage, Eastern Panama, by C. M. Breder, Jr. (1927), and A List of the Fresh Water Fishes of Western Panama between Long. $81^{\circ} 45^{\prime}$ and $83^{\circ} 15^{\prime} \mathrm{W}$., by Dr. Ellinor H. Behre (1928). These reported a considerable number of species previously not recorded from Panama. Several smaller papers have appeared, and are referred to in appropriate places in the accounts of species, and are listed in the "References." Unfortunately, comparatively few of the specimens on which these later papers were based have been available to me for examination.

The number of species reported from the fresh waters of the Republic in our earlier (1916) work has been increased from 94 to 127.

1 Published by permission of the United States Commissioner of Fisheries. 
A further increase is expected, as most of western Panama, and a considerable part of the Atlantic slope of eastern Panama remain ichthyologically virtually unexplored.

The designations western, central, and eastern Panama are used freely in this paper. It is understood, of course, that there are no such political divisions. As here used western Panama includes the states of Bocas del Toro and Chiriquí, while central Panama includes the Canal Zone and the territory westward on the Pacific slope a distance of about 70 miles. The Atlantic slope west of the Canal Zone is not included because no collections have been made there, except at Bocas del Toro, which is included in western Panama. Eastward, central Panama includes the territory as far as Porto Bello on the Atlantic and the Bayano Basin on the Pacific. Eastern Panama consists principally of the Tuyra Basin, including two large rivers, the Tuyra and the Chucunaque. The narrow Atlantic slope from Porto Bello to the Colombian border remains virtually unexplored.

Only those species which live more or less constantly in fresh water are included. A few, such as some of the Gobiidae (now usually placed in a separate family, Eleotridae), and a few of the Poeciliidae, descend to brackish water. On the other hand, several species belonging to marine families, which dwell in the fresh water of Panama more or less commonly, such as one of the Syngnathidae (Doryrhamphus lineatus), one of the Atherinidae (Menidia chagresi), several species of Centropomidae, the tarpon, and several others, are not included. These will be dealt with mostly in a paper now in preparation, pertaining to the use of the Panama Canal and its locks as a passageway for fishes.

Two papers (Hildebrand, 1935 and 1937) based on these investigations have been published. It is proposed also to publish one or more papers on extensive collections of marine fishes made on both coasts of Panama, and the Pearl Islands, wherein species ranging into fresh water probably will be dealt with still further. It may be added that marine fishes have invaded the fresh water of the Canal to a remarkable degree.

The order of families, genera, and species used in our earlier work has been retained as far as practicable. Only such changes in nomenclature as seemed well founded have been made. Wherever recently proposed changes in nomenclature of families and genera have not been followed the reasons are stated. 
The proportions and counts given were derived by the same methods as in the earlier work. It seems sufficient to state only that the scale counts, unless otherwise stated, show the number of oblique series of scales (running upward and backward) crossing a straight line between the upper anterior angle of the gill opening and the base of the caudal. The counts in Arabic numerals of soft rays of the fins include undivided or rudimentary rays, unless otherwise stated. Definitely developed spines are always given in Roman numerals.

\section{NOTES ON THE ORIGIN AND DISTRIBUTION}

\section{OF PANAMA FISHES}

It was pointed out in our earlier work that the fresh-water fishes of Panama, known at that time, when western Panama remained unexplored, were chiefly of South American origin. Principally through the work of Dr. Behre (1928) it has since been learned that the fish fauna of western Panama is composed largely of Central American forms. In fact, comparatively few of the species of central Panama have been taken in western Panama.

The Loricariidae, with one exception (Plecostomus plecostomus panamensis), apparently do not reach western Panama, though seven species, some of which are common, are found in central Panama.

The Characinidae are much less numerous in western than in central Panama, and the species found there are largely different. Only nine species are known from western Panama, whereas 32 are reported in this paper from central and eastern Panama, and only two (possibly three) are common to both regions.

It is evident, then, that the Loricariidae and the Characinidae, two large and rather typical South American families of fresh-water fishes, mostly reach the northern (western) limits of their range in central Panama. A similar distribution, that is, dissimilarity of species, exists among other families, though perhaps less clearly.

On the other hand, the family Cichlidae, which is more numerous in Central than in South America, has a larger number of representatives in western than in central Panama, there being 11 species recorded from the first-mentioned region and six (two of which are doubtful) from the last-mentioned one. Three (possibly four) are common to both regions.

Because of the unexplored intermediate territory, it cannot yet be stated where the Central American fauna ends and the South American one begins, if in fact a definite division exists. 
Meager data suggesting a crossing over from the Atlantic to the Pacific slope in western Panama were obtained. This crossing over is suggested by three species of characins; namely, Brycon obscurus, taken at El Valle, and Brycon behreae and Roeboides guatemalensis, in the vicinity of Caldera. The specimens upon which Behre (1928, p. 318) based the Caldera record of the last-named species were not seen by me. The other two, described herein as new, are extremely closely related to Atlantic slope (Chagres River) forms, and rather remotely to species found east of $\mathrm{El}$ Valle. Bryconamericus zeteki from El Valle, here described as new, is very closely related to $B$. emperador, which occurs on both slopes in the vicinity of the Canal Zone, but apparently not at El Valle. B. zeteki, too, may have reached this locality from the Atlantic slope, as the indications are that the Pacific slope characins of central Panama have not reached El Valle.

According to the most authentic information obtainable, the two streams sampled in El Valle, a small, flat area supposedly the crater of an extinct volcano, are both branches of the Antón River, a Pacific slope stream, though a small branch of the Rio Indio, a tributary of the Atlantic, cuts into El Valle. Evidently the streams of the opposite slopes approach each other closely in El Valle. Possibly with the aid of high water, or through volcanic action as suggested elsewhere, a transfer of fish from one slope to the other may have taken place here. Farther westward, where there is evidence of comparatively recent volcanic action, further transfers may have occurred.

It is interesting that such common species of characins of the Pacific slope of central Panama as Brycon striatulus, Brycon argenteus and Roeboides occidentalis apparently do not occur in western Panama, and perhaps not even as far westward as El Valle, where an influx of Atlantic slope species apparently has taken place. The specimens listed as Brycon striatulus from western Panama by Behre (1928, p. 317) have been restudied and found to belong to an undescribed species here named $B$. behreae.

It is surprising that the exceedingly abundant characin, Astyanax ruberrimus, of both slopes of central Panama, was also missing at El Valle, though it was common near there in streams toward the Canal Zone side of a high ridge. Neither has this species been taken farther westward. A related species, recorded as this one by me (1928, p. 83) was secured in certain volcanic lakes, near Volcán, Chiriquí. Several differences were found, however, upon comparison 
and careful study of specimens from central and western Panama. The Volcán material is apparently new and is named Astyanax kompi.

It is interesting that in my investigations in the Chiriquí Viejo Basin no native fish was found above an elevation of about 5,000 feet. Only Brachyraphis terrabensis was found, at altitudes of about 4,800 to 5,000 feet. Down to about 4,200 feet, below which no collections were made, Rhamdia rogersi and many Brachyraphis terrabensis were taken. Agonostomus was seen, but not captured. In lakes Gulnar and Grande, which supposedly occupy the craters of extinct volcanoes, situated at an elevation of about 4,500 feet, Brachyraphis terrabensis and Astyanax kompi were numerous, and Rivulus volcanus was common. The last-named, also, is described here as new.

It might be supposed that the rainbow trout had eradicated the native species in the upper stretches of the Rio Chiriquí Viejo. However, in Puerto Rico, where no introductions had been made in most of the streams examined, the writer (1935) found few or no fishes above an elevation of 1,500 to 2,000 feet, the species apparently being unable to penetrate the colder water of the upper stretches of the streams. It seems probable that a similar situation prevails in the Rio Chiriquí Viejo.

The relationship of the fishes of the Chagres Basin and opposing Pacific slope streams, including the Bayano, were discussed in the introduction to our earlier work. There is little to be added. As pointed out previously, the species of the opposite slopes in central Panama are very similar. Some differ in minor, but apparently constant, characters. Others remain identical. Yet it is undoubtedly correct to say that the fishes of the opposite slopes of central Panama are more dissimilar; that is, they have "drifted" farther apart, morphologically, than the fishes of the Pacific slope of eastern Panama and the Atlantic slope of Colombia. In other words, the fishes of the Tuyra Basin and those of the Atrato and Magdalena basins are more closely related, morphologically, than the fishes of the Chagres Basin and the opposing Pacific slope streams. A greater difference exists, however, between the fishes of the Chagres and those of the Atrato and Magdalena.

Although the number of identical species occurring in different streams is not an absolute criterion of the relationship of the faunas, yet it seems rather significant. Accordingly the following numbers are presented, in which the fresh and brackish water gobies with separate ventrals, that is, the Eleotridae, are omitted because they are not 
strictly fresh-water fishes. Several doubtful records of fishes of other families are also excluded. After these exclusions have been made, there remain records of 21 species common to both slopes of central Panama, and 37 that inhabit only one slope. Comprising the latter are 16 from the Atlantic and 21 from the Pacific slope.

Breder (1927) discussed the relationship of the fishes of the Bayano and Tuyra basins. As no new collections have been made in these rivers Mr. Breder's remarks stand substantially as reported. There are listed in these pages 32 species common to the basins of these streams, as compared with 18 species common to the Bayano and the Chagres basins. Breder pointed out the apparently close approach of the upper branches of the Bayano and the Chucunaque, and the possibility of a recent connection. The rather large number of identical species seems to show that a comparatively recent passageway for fishes existed.

The relationship of the fishes of the Tuyra and the Atrato basins was discussed briefly in our earlier work. Since that time Eigenmann (1920) has given it further attention. In the present paper 26 species are listed from the Tuyra, which Eigenmann (1922) also listed from the Atrato and the Magdalena. The close approach of the upper tributaries of the Atrato and the Tuyra was pointed out in our earlier work. That the Indians to the present time drag their wooden dugouts across the divide was confirmed recently by an eyewitness. It is not surprising, therefore, that a considerable number of species in the two streams are identical, or at least closely related. It is interesting that only 18 of the 57 species listed from the Tuyra Basin are recorded from the Pacific slope of Colombia.

It has been stated elsewhere that the fishes of the Chagres Basin differ rather more widely from those of the Atrato and the Magdalena basins than from those of the Tuyra. In partial confirmation it may be stated that 12 identical species are listed from the Chagres and the Atrato and Magdalena basins, whereas 17 identical species are recorded from the Chagres and the Tuyra basins.

The information gained since our earlier work was printed, then, seems to show more clearly that most of the fishes of eastern and central Panama are of South American origin. The principal route of migration apparently was from the Atlantic slope of Colombia to the Pacific slope of eastern and central Panama. The most probable route is from the Atrato to the Tuyra; from the Tuyra to the Bayano; and from the Bayano and neighboring coastal streams to the Chagres. The slight information suggesting a "re-recrossing" in western Panama 
has already been stated. The fishes of far western Panama, however, are chiefly Central American.

I am pleased to quote from a letter by R. A. Terry, the geologist who has explored Panama extensively, findings that seem to be in agreement with the indicated connections of Atlantic and Pacific slope streams shown by the distribution and relationship of the fish faunas of various streams of Panama. In a sketch map $\mathrm{Mr}$. Terry shows the close approach of the headwaters of the Tuyra and the Atrato rivers on the Panama-Colombia border. He says: "It seems likely that branches of the upper Tuyra have been pirated (cut into) by the Salaquí (an upper tributary of the Atrato), thus transferring Atrato fishes to the Tuyra .... Just when it took place I do not know, further than that it must have been subsequent to the late Pleistocene (or post-Pleistocene) elevation.

"A similar favorable stream piracy occurs between the heads of the Chillibrillo and the María Prieta just east of the Canal Zone, where limestone sinks occur almost on the continental divide, which is quite flat. These sinks might conceivably be shifted from one drainage to the other by the development of solution channels irrespective of the normal erosive power of the streams to which they drain.

"In the El Valle region the eruption which formed the El Valle volcanic crater with its surrounding walls must have been terminated earlier than the late Pleistocene, or post-Pleistocene time. I suspect that shifting of stream channels by this late vulcanism is responsible for the migration of species in this region, and also in the vicinity of Caldera, where the ejecta of the Chiriquí Volcano have obviously changed the drainage system of the region greatly."

\section{INTRODUCTION OF FISHES}

The first record of introduction which has been found, is contained in Mosquito Control in Panama, by J. A. Le Prince and A. J. Orenstein $(1916$, p. 185), where it is reported that Girardinus poecillodes (=Lebistes reticulatus) the "millions fish" or "guppy" was brought from Barbados. The date of introduction is not given, but in a recent letter $\mathrm{Mr}$. Le Prince states that the fish were brought about 1910 or 1912 . The few fish received were bred in captivity for a time; they multiplied rapidly; and batches were liberated in several places now included in Gatun Lake. As no specimens have been reported from Panama since the introduction was made, the species apparently failed to become established. It is highly prob- 
able that some of the native species of viviparous top minnows, especially Gambusia nicaraguensis, Brachyraphis episcopi, and Allogambusia tridentiger, are even more useful for mosquito control. Mr. Le Prince, who was chief- sanitary inspector for the Isthmian Commission from 1904 to 1914, knows of no other introductions of top minnows.

Upon the request of the Canal Zone authorities, at least two shipments of young fish, one in 1917 and another in 1925, have been made. The first shipment consisted of " 450 large mouth bass, 1,000 catfish, and 800 sunfish." The second one contained " 2,250 large mouth bass, 500 blue-gills and 500 crappies." The fish, according to a Canal Zone informant, were planted in Gatun Lake, at Gatun, immediately upon arrival. These plants apparently failed, as no specimens of the fish introduced were seen or taken during my visits in 1935 and 1937. The stray reports of the capture of bluegills and a crappie, such as was once reported in Fisheries Service Bulletin No. 182, 1925, may have resulted from misidentifications by the reporters. I was able to trace one such erroneous report. A certain Canal employe, who claimed that the bluegill had become established, without hesitancy identified Cichlasoma maculicauda as the bluegill, when specimens of this cichlid were placed before him.

The only introduction that has been a success, to date, is that of the rainbow trout, introduced into the Rio Chiriquí Viejo in western Panama, in 1925, through a shipment of eggs. The writer spent several days on this river, in 1935 , between an elevation of about 4,500 and 7,000 feet. Above an altitude of about 5,000 feet the trout probably are as abundant as in any stream in the United States. At lower elevations the temperature is too high for trout. Trout-fishing in the high altitude, where the nights are always cool, if not cold, is giving enjoyable recreation to many Canal employees, as well as others, who visit there from time to time. An account of the status of this introduction, together with some records of temperature and foods utilized by the trout, was given by me (1935) in the Bulletin of the Pan-American Union. Inadvertently the number of eggs planted was stated as 2,500 in the article cited, whereas 25,000 eggs were actually sent.

No doubt rainbow trout would thrive in other mountain streams of western Panama, where the maximum temperature is $70^{\circ} \mathrm{F}$. or less. It has been reported that an introduction in the vicinity of Boquete, presumably in the upper tributaries of the Rio Chiriquí, is beginning to yield returns. 
At present the lakes of the Canal support few food and game fishes. The few that provide sport and food are mostly migrants from the sea, the most important one being the tarpon, as pointed out in my recent (1937) paper. There is no commercial fishery, worthy of the name. It does seem that such a fine large body of water as Gatun Lake, having an area of 196 square miles and a shore line about 1,100 miles long, should be more productive. The newly created Madden Lake, with an area of 18 square miles, apparently should support food and game fishes after the dense vegetation covered has decayed in part and settled.

The temperature of the lakes seemingly would not preclude some of the warm-water fishes of the United States, which have been introduced successfully in Puerto Rico, Cuba, and elsewhere. According to Canal records furnished through the courtesy of Mr. R. Z. Kirkpatrick, the minimum surface temperature of Gatun Lake during any one month from 1919 to 1936 inclusive, based on two daily readings, one at 8:00 A.M. and another at 2:00 P.M., was $80.9^{\circ} \mathrm{F}$., which occurred during January, 1928. The maximum for readings, taken at the same time and place, was $86.2^{\circ}$, reached in June, 1930. The average yearly temperature, based on the same records, has fluctuated from $82.6^{\circ}$ in 1927 to $84.8^{\circ}$ in 1930 . The indications are that the temperature of the recently formed Madden Lake will be only a few degrees lower than that of Gatun Lake. The cold of the northern winters and the heat of the summers are only very slightly reflected as far south as Panama.

The native river fishes of the vicinity do not seem to have become numerous in the lakes, exclusive of the small characin ("sardina"), Astyanax ruberrimus, which is exceedingly abundant. As this fish reaches a length of only about $75 \mathrm{~mm}$. it is too small to be of direct value as food for man. If this fish could be utilized as food for larger fishes it might still be valuable. It is not evident just yet how that can be done without sacrificing the top minnows, which must be preserved, as shown subsequently.

In the endeavor to make the fresh waters of the Canal productive, the first step apparently should be an investigation of these waters and their animal and plant life, including a careful study of the life habits (especially breeding) of the native fishes. Introductions should be considered only after a careful study of the indigenous fishes has been made.

Three native species of fresh-water fishes would seem worthy of special study; namely, the two "sábalo pepons," Brycon chagrensis 
and B. petrosus, and the "mojarra," Cichlasoma maculicauda. Although the sábalo pepons grow much larger, reaching a length of two feet or so, the mojarra, which resembles the bluegill superficially, and reaches a similar size, probably is the most promising. The lastmentioned species is already fairly common in Gatun and Miraflores lakes. Its food and game qualities, however, seem largely unknown.

Great care should be exercised as to introductions of food and game fishes, because the population of top minnows (Poeciliidae) in the lakes must be maintained for the purpose of mosquito and malaria control. Certainly such highly predatory fishes as the large mouth bass and the pikes and pickerels should not be introduced. Less destructive species, as for example, the bluegill sunfish and the bullhead catfish, might be considered. The introduction of carp has been suggested by Colonel H. C. Pilsbury, Chief Health Officer, who expressed the hope that it might become numerous enough to thin the plant growth and thereby aid the top minnows in destroying larval mosquitoes. The carp, of course, is not highly regarded as a food fish, and scarcely ranks as a game fish, though it can be caught on a hook with the use of vegetable baits. Once hooked, it puts up a good fight. It seems only remotely probable, however, that the carp would become abundant enough to make appreciable inroads on the very extensive plant growth present.

It may be remarked that it seems useless to attempt the further introduction of fry or fingerlings, as earlier attempts failed completely. It would seem necessary to introduce fish too large to be managed by the exceedingly abundant and highly predatory "sardina," Astyanax ruberrimus. Whether the introduced fishes could breed, even if they themselves survived, is problematical. It might be necessary to maintain hatcheries to keep the lakes stocked, which would be expensive if virtually no reproduction took place naturally. It is evident, then, from the foregoing that the establishment and the maintenance of food fishes in the artificial lakes of the Canal is a complicated matter which should receive further study.

\section{NEW AND ABANDONED LOCALITIES}

As many changes in local nomenclature have taken place in the Canal Zone, and in the Chagres Basin beyond the Canal Zone, since 1911 and 1912 when our previous collections were made, a brief explanation seems desirable. Several towns listed as collecting stations in our earlier work no longer exist. Some of these were abandoned because the ground on which they were situated was 
flooded; others were not needed after the construction of the Canal had been completed; and a few became rather inaccessible through the flooding of the Canal and the relocation of the Panama Railroad. Names of a few new localities also appear in the present report.

As an aid to those who may use the earlier, as well as the present work, the changes are listed in the order they occur or occurred from the Atlantic terminus of the Canal southward. The changes in the Chagres Basin east of the Canal Zone also are discussed.

Toro Point, situated across Limón Bay from Colón and Cristobal, is now generally called Fort Sherman.

Mindi, formerly situated a short distance south of Mount Hope, no longer exists.

New Gatun has been replaced in approximately the same locality by Fort Wm. D. Davis. Gatun itself remains situated in its former location; namely, at the place where the Chagres River was dammed to form Gatun Lake.

Monte Lirio, formerly situated on the Rio Gatun, is now on an island in Gatun Lake, the river being almost wholly included in the lake.

Agua Clara, situated on the Rio Trinidad, a large tributary of the Rio Chagres west of the route of the Canal, was flooded and abandoned.

Bohio, situated on the route of the Canal, about 15 miles south of Gatun, came within the flooded area and had to be abandoned.

Barro Colorado Island is one of the new localities where collections were made during the present investigation. Formerly a high hill, it is now the largest island in Gatun Lake. It has been made a wild life preserve, and upon it is situated the laboratory of the Institute for Research in Tropical America. This island lies westward across Gatun Lake from the railway station, Frijoles.

Tabernilla, Gorgona and Bas Obispo, all along the direct route of the Canal and the Chagres River, were flooded and abandoned.

Gamboa, situated near Bas Obispo, was not used as a collecting station in 1911 and 1912. It is now one of the important stations on the Panama Railroad. In 1935 when collections were made in the upper end of Gatun Lake, it served as a collecting station. Accordingly, the name appears several times in the present catalogue.

Beyond Gamboa, and on the west side of the then proposed Canal, were situated the important towns, Empire and Culebra. The latter, at the summit of the divide, was the headquarters of the Isthmian 
Canal Commission during the construction of the Canal. Though these places are shown on current maps they have virtually been abandoned, having became rather inacessible when the Panama Railroad was relocated on the east side of the Canal.

Summit is one of the new localities appearing in the present work. As its name indicates, it is situated at the summit of the divide, on the relocated railroad. It is the seat of a botanical experiment station.

Miraflores Lake and the Rio Cocoli appear as new localities in the present work. The lake is a small body of water situated on the Pacific side of the divide between Pedro Miguel and Miraflores Locks. It was formed by damming the now virtually destroyed Rio Grande. Its chief tributary is the Rio Cocoli. Sometimes, with the operation of Miraflores Locks, the lower flight of which is at sea level, the main body of this lake becomes slightly brackish, but not so much so as to exclude fresh-water fishes. This lake is connected with Culebra (or Gaillard) Cut and Gatun Lake through the Pedro Miguel Locks.

Alhajuela, an important collecting station during our earlier investigations, was at that time situated on the banks of the Chagres River, about a day's journey by cayuca upstream (eastward) from Gamboa, outside the Canal Zone. It served as a hydrographic station. It has now been abandoned, but the main building still stands, and is situated at the head of Gatun Lake, just below the recently constructed Madden Dam.

San Juan, formerly on the banks of the Rio Boquerón, a short distance above the union of this stream with the Chagres, is now situated on the newly formed Madden Lake, having been moved from its former location, which was flooded. Specimens listed in the present paper from the "mouth of the Boquerón" were taken some distance upstream from the former location of San Juan, where this river now empties into Madden Lake.

Most of the stretches of the upper Chagres and the Rio Indio, in which collections were made in 1911, now are included in or at least affected by Madden Lake.

\section{ACKNOWLEDGMENTS}

Most excellent cooperation, direct help, and innumerable courtesies were extended during the investigations by more individuals than space will permit me to mention. I feel deeply grateful to all. The investigations were first suggested by Dr. Herbert C. Clark, director of the Gorgas Memorial Laboratory, Panama City. Without his 
constant cooperation, including financial aid, the work could not have been done. I am deeply indebted, also, to Dr. A. O. Foster, of the Gorgas Memorial Laboratory, for much help and the collection of many specimens. Thanks, in fact, are due the entire staff of the laboratory, all of whom cooperated most excellently.

The officers of the Panama Canal gave valuable aid. Among these must be mentioned Colonel C. S. Ridley, Governor; Colonel Glen E. Edgerton, Engineer of Maintenance; Major W. D. Styer, Assistant Engineer of Maintenance; Mr. R. Z. Kirkpatrick, Chief of Surveys; Mr. E. D. Stillwell, Superintendent of Locks; and Messrs. H. M. Thomas and J. C. Myrick, Assistant Superintendents of Locks.

Among others who cooperated, and to whom I am deeply indebted, are Mr. W. H. W. Komp, of the United States Public Health Service; Mr. J. B. Shropshire, malariologist with the United States Army; Mr. Fred Whaler, the ardent angler and student of Panama fishes; Mr. R. G. Lewis, business man of Panama City; Professor James Zetek, the well-known Canal Zone biologist; Mr. George O. Lee and Miss Elinor D. Robinson, of the Canal Zone schools; and Messrs. R. B. Potter, S. A. Venable, Carl G. Brown, and R. A. Cauthers. Finally I must thank Alfred C. Weed, Curator of Fishes, Field Museum, for critically reading and editing the manuscript.

New Species Described

$\begin{array}{ll}\text { Gephyrocharax whaleri } & \text { Brycon obscurus } \\ \text { Astyanax kompi } & \text { Rivulus volcanus } \\ \text { Bryconamericus zeteki } & \text { Rivulus montium } \\ \text { Brycon behreae } & \text { Euleptoeleotris (gen. nov.) clarki } \\ & \text { Euleptoeleotris shropshirei }\end{array}$

\section{CATALOGUE OF SPECIES}

Family PIMELODIDAE. Naked Central and South American Catfishes

The genera appearing under Pimelodidae herein were placed under Siluridae in our earlier (1916) work. During recent years there has been a tendency to follow Regan (1911), who divided Siluridae into several families. The family Pimelodidae, as defined in part by Regan, is characterized by the separate gill membranes, which are free from the isthmus; 3 pairs of barbels (1 pair maxillary, 2 pairs mandibular, and no nasal barbels); anterior and posterior nostrils far apart; 6-rayed ventrals; and a well-developed adipose.

The key to the genera under the family Siluridae in our earlier publication may be followed, except that the second part relating to 
the humeral process, under $c$ and $c c$, should be transposed (see under Pimelodus).

\section{Rhamdia Bleeker.}

On the basis of records by Behre (1928) and myself (1928), and some additional specimens obtained recently, three species of this genus not included in our earlier work are added to the fauna of Panama. These three species are all Central American forms that have invaded western Panama.

The chief diagnostic characters of this genus are the weak, flexible dorsal spine; the short occipital process which does not reach the dorsal plate; the free orbital margin; and the rather long adipose fin which is adnate to the back.

The species are imperfectly understood. For this reason no key is offered, though characters that are supposedly diagnostic are mentioned in the accounts.

\section{Rhamdia wagneri (Günther).}

Pimelodus wagneri Günther, Trans. Zool. Soc. Lond., 1868, p. 474-Atlantic and Pacific rivers of Panama.

Rhamdia wagneri Meek and Hildebrand, Field Mus. Nat. Hist., Zool. Ser., 10, p. 240, 1916.

This common species was secured during the recent investigations in a stream flowing through Chillibrillo Cave, at Barro Colorado Island, and in a small creek flowing into an abandoned reservoir near Gatun. Since our earlier publication (1916) it has been recorded from several places in the Rio Chucunaque Basin by Breder (1927, p. 101), and from streams of both slopes of extreme western Panama by Behre (1928, p. 307).

The very long adipose fin, which begins in advance of the tips of the dorsal rays if deflexed, and which is much longer than the head; the very long maxillary barbel, which often reaches beyond the ventral; and the well-forked caudal aid in identifying this species.

Not much in evidence during the dry season, but when the wet season comes in April and May it schools. The writer has seen a dozen or more individuals swimming leisurely at the surface in quiet places among grass in the swollen streams, where they could be captured easily. It is evident that this fish does not find darkness objectionable, as it was common in a small stream in Chillibrillo Cave.

Attains a length of about $400 \mathrm{~mm}$. (12 inches), and is said to be a food fish of good quality. 
This species, as now understood, ranges from Costa Rica, southward into Colombia, possibly to Ecuador, and is common on both slopes of Panama, and in Colombia.

Rhamdia godmani (Günther).

Pimelodus godmani Günther, Cat. Fish. Brit. Mus., 5, p. 124, 1864-Vera Cruz, Mexico; Rio Motagua, Guatemala.

Included on the basis of a record by Behre $(1928, p .306)$ founded on specimens taken in the Rio Cricamola, on the Atlantic slope of extreme western Panama. $R$. godmani has not been reported from Costa Rica. Dr. Behre found her specimens to be somewhat intermediate in some respects between wagneri and underwoodi, and not entirely in conformity with godmani. I have not seen these specimens, but on the basis of distribution a new species is suggested, as godmani was recorded only from Vera Cruz, and Yucatan, Mexico; from the Rios Motagua and Usumacinta, Guatemala; and from Belize prior to Dr. Behre's record. Dr. Behre mentions a "Pacific coast" record from Honduras, and refers to godmani as "a north Pacific-coast form," but I have not been able to find a record of its occurrence on the Pacific slope. It seems somewhat significant that Meek (1914) did not record it from Costa Rica, and that the species was not recognized among the specimens from Costa Rica studied by me (1930).

This species seems to be characterized by the rather well-forked caudal fin; the short occipital process, which extends less than half the distance from its base to the origin of the dorsal; and the moderately long adipose, which is longer than in rogersi, but shorter than in wagneri, being about $1 \frac{1}{2}$ times the length of the head.

\section{Rhamdia underwoodi Regan.}

Rhamdia underwoodi Regan, Biol. Cent. Amer., Pisces, p. 135, pl. 23, fig. 4, 1907 - Juan Viñas, Costa Rica.

Included in the fauna of Panama on the basis of specimens taken by Behre (1928, p. 308 ) in the Rio Cricamola, on the Atlantic slope of extreme western Panama. Recorded also from both slopes of Costa Rica.

This species is characterized by the rather deeply notched (not forked) caudal, the very short occipital process, which reaches only about one-fifth to one-sixth the distance from its base to the origin of the dorsal; the rather short adipose, which is not much longer than the head; and the short maxillary barbel, which reaches only about to the tips of the pectoral. 
Rhamdia rogersi (Regan).

Pimelodus rogersi Regan, Ann. Mag. Nat. Hist., (7), 19, p. 259, 1907Irazú, Costa Rica.

Taken with hook and line in Miller's Spring, flowing into a tributary of the Rio Chiriquí Viejo, Pacific slope of extreme western Panama, from whence it was already recorded by Hildebrand (1928, p. 82).

Differs prominently from $R$. wagneri in the much shorter adipose fin, which begins far behind the tips of the dorsal rays, and is little if any longer than the head; in the much shorter maxillary barbel, which fails to reach the tips of the pectorals; and in the unforked caudal fin, which has only a slight notch.

It was originally described from Irazú, Costa Rica. It has been recorded from both slopes of Costa Rica; and from the Pacific slope of extreme western Panama, on the basis of specimens already mentioned.

\section{Pimelodus Lacépède.}

This genus differs prominently from Pimelodella in the much shorter and broader humeral process. Unfortunately, in the key to the genera in our earlier work $(1916$, p. 239) this well-marked difference between this genus and Pimelodella was transposed. When using that key, "humeral process broad, not spine-like," under $c c$, should be exchanged with "humeral process spine-like" under $c$. This difference is correctly stated in the descriptions of the genera. A single species is known from Panama.

\section{Pimelodus clarias punctatus (Meek and Hildebrand).}

Megalonema punctatum Meek and Hildebrand, Field Mus. Nat. Hist., Zool. Ser., 10, p. 77, 1913-Rio Tuyra at Marrigante.

Pimelodus clarias punctatus Meek and Hildebrand, Field Mus. Nat. Hist., Zool. Ser., 10, p. 241, 1916.

This subspecies is known only from the Tuyra Basin. Since the publication of our earlier work (1916), Breder (1927, p. 103) has recorded many specimens from the Rio Chucunaque, having found it nearly as common as Rhamdia wagneri.

Pimelodella Eigenmann and Eigenmann.

This genus is recognized by the stiff pungent dorsal spine; the deeply forked caudal; the long occipital process, which reaches the dorsal plate; the narrow spine-like humeral process, which reaches nearly opposite mid-length of the pectoral spine; and the free orbital 
margin. In the key to the genera in our earlier work (1916) the differences in the humeral processes of this genus and Pimelodus were inadvertently transposed (see under the genus Pimelodus).

Pimelodella chagresi (Steindachner).

Pimelodus (Pseudorhamdia) chagresi Steindachner, Sitzber. Akad. Wiss. Wien, 74, p. 584, 1876 - Rio Chagres and tributaries.

Pimelodella chagresi Meek and Hildebrand, Field Mus. Nat. Hist., Zool. Ser., 10, p. 242, 1916.

This common catfish was secured in Miraflores Lake and in the Rio Cocoli a short distance from the lake, and also in the Rio Cabra on the Panama City-Chepo Road. It is common on both slopes of central Panama and also in the Tuyra Basin of eastern Panama. Since our earlier work was published it was obtained by Breder (1927, p. 102) at several places in the Rio Chucunaque and tributaries, and through a record by Behre $(1928$, p. 308), based on specimens secured in the Rio Chiriquí del Tire, Pacific slope of western Panama, the range was extended considerably westward from the Canal Zone. The range as now understood extends from western Panama into Colombia, where it occurs in the Atrato and Magdalena basins. It is definitely known from both slopes only in central Panama.

This species should be handled with care, as it secretes the most painful poison of any catfish ever handled by the writer, who suffered severely for a half hour or so after being "finned," and who saw a native roll on the ground in agony after a like experience. Fortunately, no bad after effects were noticed.

This fish does not grow large enough to be of value as food, as it apparently seldom reaches a length as great as $150 \mathrm{~mm}$. (6 inches).

\section{Trachycorystes amblops (Meek and Hildebrand).}

Felichthys amblops Meek and Hildebrand, Field Mus. Nat. Hist., Zool. Ser., 10, p. 77, 1913-Rio Tuyra at Marrigante.

Trachycorystes amblops Meek and Hildebrand, Field Mus. Nat. Hist., Zool. Ser., 10, p. 243, 1916.

Three small specimens, respectively 43,54 , and $63 \mathrm{~mm}$. long, were taken in a swamp at the La Jagua Hunting Club, situated on the Pacific slope, about 15 miles east of Panama City. This species was known heretofore only from the lower part of the Rio Tuyra Basin from specimens reported in our earlier work (1916, p. 243) and by Breder (1927, p. 104).

The specimens at hand agree well with the Rio Tuyra material. The sides are marked with dark longitudinally elongate spots, which are almost united along middle of side in the $54 \mathrm{~mm}$. specimen, form- 
ing a lateral band. The description in our earlier work stated that the dorsal spine had "barbels" on the anterior margin. "Barbs" obviously should be.substituted for "barbels."

The following proportions and counts are based on the three small specimens at hand: Head 3.4 to 3.9 ; depth 3.6 to 3.7 ; D. I, 5 or 6 ; A. 18 to 20 . Snout 4 to 4.4 in head; eye 5.6 to 6.3 ; interorbital 1.4 to 1.8 ; caudal peduncle 2.5 to 2.8 . Pectoral spine 3.9 to 4.7 in standard length.

Ageneiosus Lacépède.

Maxillary barbels only are present in this genus; the orbital margin is not free; the occipital process is joined to the dorsal plate, and the humeral process is wanting. The single species of this genus known from Panama has been taken there only in the Tuyra Basin.

Ageneiosus caucanus Steindachner.

Ageneiosus caucanus Steindachner, Denkschr. Akad. Wiss. Wien, 41, p. 61, pl. 6, figs. 1, 2, 1880-Rio Cauca; Meek and Hildebrand, Field Mus. Nat. Hist., Zool. Ser., 10, p. 245, 1916.

This fish, known in Panama only from the Tuyra Basin, has been reported, since the publication of our earlier work, by Breder (1927, p. 104) from the Rio Chucunaque at the island below Yavisa. According to Eigenmann (1922, p. 50) this species occurs also in the Atrato and Magdalena basins.

\section{Family LORICARIIDAE. Mailed Catfishes}

This family of South American Nematognathi ranges northward into eastern and central Panama, the northernmost record for Panama being "Veragua," presumably meaning the State of Veraguás (see under Plecostomus plecostomus panamensis). No representatives of the family have been found in extreme western Panama, that is, in the states of Chiriquí and Bocas del Toro, where Dr. Ellinor $\mathrm{H}$. Behre and others have collected. However, there is a record in the National Museum of a Plecostomus plecostomus taken in the Quebrada de India, Colorado de Coto, Costa Rica. The species are widely distributed in South America. Charles M. Breder, Jr. (1925 and 1927) working in the Chucunaque Basin of eastern Panama, added many records from that river system, and described a new species.

We are indebted to Mr. Breder also for information in regard to the food of these fishes. In general the intestinal tract is long and convoluted, as typical of herbivorous fishes. It is much longer, however, in members of the subfamily Plecostominae, including the genera Plecostomus, Chaetostomus, Ancistrus, Lasiancistrus, and 
Leptoancistrus, than in the members of the subfamily Loricariinae, which includes among the Panama fauna the genera Loricaria and Sturisoma. The food in all the species consisted of a flocculent material, composed largely of algae and mud, which is probably obtained, by scraping and sucking, from the rocks and pebbles among which the species commonly live.

\section{Plecostomus plecostomus panamensis Eigenmann.}

Plecostomus plecostomus panamensis Eigenmann, Mem. Carnegie Mus., 9, No. 1, p. 69, 1922-Chagres River at Monte Lirio and Gatun.

This fish, like Ancistrus chagresi, commonly lives in streams among the rocks. It seemed to be more numerous than the relative just mentioned during our work in 1911 and 1912. Only one specimen, $345 \mathrm{~mm}$. long, was taken during the recent investigation. This one was secured in Miraflores Lake at the mouth of the Rio Cocoli. This capture does not show, however, that the species is living under lake conditions. It evidently was not taken oftener in 1935 and 1937 because little collecting was done in rocky streams, its usual habitat.

The very long convoluted intestine is generally filled with a slimy mass, apparently mostly of vegetable origin. Breder (1927, p. 108) stated that the intestines were "all packed with soft flocculent mud, algae, et cetera." It clings closely to stones. In 1912, while collecting in the upper Tuyra Basin, the fish could be seen clinging to stones, and we succeeded in capturing a few specimens by lifting stones with fish attached, from the water. The fish clung to the stones so tightly with their sucking mouth and flat chest and abdomen, that it took some little power to remove them.

This species is listed as $P$. plecostomus in our earlier work (1916, p. 247). However, Eigenmann (1922, p. 69) found the Panama specimens to differ from typical $P$. plecostomus of South America in having the occipital plate bordered by several (3 or more) small plates instead of 1 or 2 larger ones. Accordingly, Eigenmann recognized the Panama specimens as representatives of a new subspecies, for which he offered the name panamensis.

To the synonymy in our earlier work should be added Plecostomus bicirrhosus Günther (1866, p. 477), reported from "Pacific and Atlantic coast rivers of Panama," and Plecostomus guacari Regan (1907, p. 111).

Although Eigenmann (1922, p. 75) recognized Chaetostomus aspidolepis Günther (1866, p. 603; and 1868, p. 477), reported from "Veragua" (presumably meaning the State of Veraguas of western 
Panama) as distinct, placing it in the genus Hemiancistrus, I shall regard it as synonymous with $P$. plecostomus panamensis for the reasons stated: Only Günther's description is available to us, which was based on a skin (presumably dry, though not so stated) 121/4 inches long. Owing to the removal of the soft parts, and drying, it probably was somewhat distorted. The apparently larger interopercular spines, which evidently led Eigenmann to place it in the genus Hemiancistrus (a genus otherwise not found in Panama), may well have seemed longer because of shrinkage. The other difference that apparently might be of some importance is the supposedly narrower head. This apparent difference also might have resulted from shrinkage. The proportionate length of the head, however, agrees with Canal Zone specimens. It probably is significant, also, that the number of fin rays and scutes given agrees with specimens that are undoubtedly $P$. plecostomus panamensis.

No Loricariidae were taken in the extreme western states of Panama, namely, Chiriquí and Bocas del Toro, by Dr. Ellinor $\mathrm{H}$. Behre, and others who collected there. Günther's record, "Veragua," therefore, remains as the westernmost one of the family in Panama. However, there is a record of a specimen in the United States National Museum, identified by Dr. George S. Myers, from the Quebrada de India, a Pacific slope stream, a tributary of the Rio Colorado, which is a tributary of the Rio Coto. Upon inquiry from Professor Manuel Valerio, the collector, I am informed that this spcies is known locally as "Arrisuaca," and that it is common enough to be used as food.

Though $P$. plecostomus ranges south to Uruguay, the subspecies panamensis, as now understood, is found in Panama, from Veraguas(?) to the Rio Tuyra Basin in Darien. In central Panama it occurs on both slopes. It is not reported from the Bayano, though it very probably occurs there. The single specimen from Costa Rica, mentioned in the preceding paragraph, very probably belongs to this subspecies.

\section{Chaetostomus fischeri Steindachner.}

Chaetostomus fischeri Steindachner, Denkschr. Akad. Wiss. Wien, 41, p. 162, pl. 4, 1879-Rio Mamoni, near Chepo; Meek and Hildebrand, Field Mus. Nat. Hist., Zool. Ser., 10, p. 249, 1916.

This species was not taken during the recent investigation probably because virtually no collecting was done in suitable places in streams. Since our earlier work (1916, p. 249) was published, Breder 
(1927, p. 109) has reported it from the Chucunaque Basin from the "Rio Chico and Sucubtí in clear water."

This species is recorded from both slopes of central Panama and from the Pacific slope of eastern Panama. Presumably it is rare in the Chagres Basin, as we took only one specimen there during our intensive collecting in 1911 and 1912. According to Eigenmann (1922, p. 82) this species occurs on both slopes of Colombia and southward into Ecuador.

Ancistrus chagresi Eigenmann and Eigenmann.

Ancistrus chagresi Eigenmann and Eigenmann, Proc. Calif. Acad. Sci., (2), 2, p. 47, 1889-Rio Chagres; Meek and Hildebrand, Field Mus. Nat. Hist., Zool. Ser., 10, p. 251, 1916.

Eight specimens, ranging in length from 37 to $235 \mathrm{~mm}$., were seined along Madden Dam Road, in a creek formerly a tributary of the Rio Chagres and now flowing into Gatun Lake. As no specimens were secured in Gatun or Miraflores Lake, it is not known whether this typical river fish is living in these artificial lakes, though it was present in some parts of the Chagres River, now included in Gatun Lake, before the canal was completed. This species commonly lives in streams on rocky bottom, clinging closely to rocks with its sucking mouth and flat chest and abdomen.

Policeman S. A. Venable of the Canal Zone, who is interested in "pet fish," kept small individuals of this species in his aquaria, when observed in 1935, to act as scavangers. This fish is sluggish in the aquarium, and as in nature it stays chiefly on the bottom.

A specimen, $75 \mathrm{~mm}$. long, when observed in Mr. Venable's aquarium, was dark green with pale round spots on the upper surface of the head and body.

This species is known only from central Panama where it has been taken on both slopes.

\section{Ancistrus spinosus Meek and Hildebrand.}

Ancistrus spinosus Meek and Hildebrand, Field Mus. Nat. Hist., Zool. Ser., 10, p. 252, 1916 - Rio Calobre, tributary to Rio Bayano.

This species was not taken during the recent investigation. It was described by us $(1916$, p. 252$)$ from only two specimens, one from the Bayano and the other from the Tuyra Basin. Since that time Breder (1927, p. 109) has reported it from five specimens taken in the Chucunaque Basin from the "Rio Chico, the Sucubti and the latter's confluent in clear water in company with Chaetostomus." 
Lasiancistrus planiceps (Meek and Hildebrand).

Ancistrus planiceps Meek and Hildebrand, Field Mus. Nat. Hist., Zool. Ser., 10, p. 79, 1913-Rio Tuyra, Boca de Cupe; Field Mus. Nat. Hist., Zool. Ser., 10, p. 253, pl. 10, 1916.

This species, described from specimens from the Rio Tuyra and its upper tributaries, has been recorded also from eight specimens by Breder (1927, p. 108) from the "Rio Chucunaque, above the mouth of the Rio Chico, at the Indian village; Rio Sucubtí, at the Indian village and the creek near it, below the falls."

\section{Leptoancistrus canensis (Meek and Hildebrand).}

Acanthicus canensis Meek and Hildebrand, Field Mus. Nat. Hist., Zool. Ser., 10, p. 80, 1913-Rio Cana, Cana, Panama.

Leptoancistrus canensis Meek and Hildebrand, Field Mus. Nat. Hist., Zool. Ser., 10, p. 254, pl. 11, 1916.

Known only from the type material collected in small mountain streams near Cana in the upper Tuyra Basin.

Loricaria uracantha Kner and Steindachner.

Loricaria uracantha Kner and Steindachner, Abhand. Bayer. Akad. Wiss. München, 10, p. 56, pl. 6, 1866-New Granada; Rio Chagres; Meek and Hildebrand, Field Mus. Nat. Hist., Zool. Ser., 10, p. 256, 1916.

A single small specimen, $55 \mathrm{~mm}$. long, was seined along the Madden Dam Road, in a creek formerly a tributary to the Rio Chagres and now flowing into Gatun Lake.

We found this species very common in streams in shallow water with swift current and a sandy or gravelly bottom in the Chagres Basin in 1911 and 1912. It evidently was not secured oftener during my recent work because very little collecting was done in suitable places.

The species has been recorded from "Atlantic and Pacific rivers of Panama," but we have taken it only in the Chagres Basin, and are inclined to doubt the Pacific slope record.

Loricaria latiura Eigenmann and Vance.

Loricaria filamentosa latiura Eigenmann and Vance, in Eigenmann, Indiana

Univ. Studies, No. 16, p. 13, 1912-Boca de Certegai, Colombia; Meek and Hildebrand, Field Mus. Nat. Hist., Zool. Ser., 10, p. 257, 1916.

This species appears under the trinomial, L. filamentosa latiura, in our earlier work. However, Eigenmann (1922, p. 91) considered latiura sufficiently different from filamentosa to give it full specific rank.

As understood by Eigenmann, L. latiura occurs in the Tuyra and Atrato basins. This is one of several species that are common 
to the Tuyra on the Pacific slope of Panama and the Atrato on the Atlantic slope of Colombia.

\section{Loricaria variegata Steindachner.}

Loricaria variegata Steindachner, Denkschr. Akad. Wiss. Wien, 41, p. 163, pl. 3, 1879-Rio Mamoni, near Chepo; Meek and Hildebrand, Field Mus. Nat. Hist., Zool. Ser., 10, p. 258, 1916.

Nine specimens, ranging in length from 16 to $210 \mathrm{~mm}$., were reported from the Chucunaque Basin by Breder (1927, p. 112). Previously the species had been recorded in Panama from the "Rio Mamoni, near Chepo" (type locality) and from the Rio Tuyra. Mr. Breder states: "The present series varies beyond the limits of the Meek and Hildebrand, 1916, description as follows: The cross-row of scutes between the pectorals is obsolescent in some specimens, being merely represented by a few scattered asperities on the otherwise smooth skin. In some cases the plates anterior to the vent are scarcely enlarged and the caudal varies from strongly emarginate to forked. The longest caudal filament ( $99 \mathrm{~mm}$.) is on a male of $199 \mathrm{~mm}$., as measured from the tip of the second, not produced, caudal ray."

According to Eigenmann (1922, p. 93), it occurs in the Atlantic drainage of Colombia in the Atrato and Magdalena basins. The extremes of the range, then, are the Rio Mamoni on the Pacific slope of Panama and the Rio Magdalena on the Atlantic slope of Colombia. It is not reported from the Pacific slope of Colombia.

Loricaria capetensis Meek and Hildebrand.

Loricaria capetensis Meek and Hildebrand, Field Mus. Nat. Hist., Zool. Ser., 10, p. 80, 1913-Rio Capetí, tributary to the Tuyra; p. 259, pl. 12, 1916.

Known only from the two original specimens from the Tuyra Basin. Breder (1927, p. 111) has questioned its validity (see under L. fimbriata).

\section{Loricaria fimbriata Eigenmann and Vance.}

Loricaria fimbriata Eigenmann and Vance, Indiana Univ. Studies, No. 16, p. 12,1912-Boca de Certegai and Bernal Creek, Colombia; Meek and Hildebrand, Field Mus. Nat. Hist., Zool. Ser., 10, p. 260, 1916.

Previously known from Panama only from 4 specimens, 50 to 80 $\mathrm{mm}$. long, taken in the Rio Capetí (tributary of the Tuyra), by Meek and Hildebrand (1916, p. 260), and reported by Breder (1927, p. 111) from a specimen $54 \mathrm{~mm}$. long, from the Rio Tupisa, tributary of the Chucunaque. Breder has suggested that three closely related species, namely, fimbriata and capetensis from the Tuyra Basin, and seminuda from Girardot on the Magdelena River in 
Colombia, should be reduced to one. These nominal species are supposedly distinguished chiefly by the differences in the development of the abdominal scutes. Since the degree of development of the scutes almost certainly depends largely upon age and size of the fish, Mr. Breder is probably correct. However, not enough specimens are available (none of seminuda) to determine definitely that no differences exist in fully mature specimens, wherein differences could not be ascribed to age.

\section{Loricaria altipinnis Breder.}

Loricaria altipinnis Breder, Amer. Mus. Nat. Hist., Nov., No. 180, p. 1, fig. 2, A and B, 1925-Rio Chico, Darien, Panama; Bull. Amer. Mus. Nat. Hist., 57, p. 110, fig. 4, 1927.

According to Breder (1925, p. 3), this fish may be distinguished from $L$. uracantha, the most closely related species in Panama, "by the anterior rays of the dorsal reaching beyond those of the posterior ones when depressed, instead of being co-terminous; the distance from the origin of dorsal to longest deflexed ray being equal to the distance from the tip of snout to posterior margin of occipital plate instead of to the middle of that plate; the distance from origin of anal to longest deflexed ray being equal to the distance from the snout to a point well past the orbital notch instead of to its posterior margin. The smaller examples differ greatly from young $L$. uracantha of the same size, as those closely resemble the larger examples of that form, instead of differing from them, as previously noted for the present species."

Mr. Breder gave the following counts and proportions, based on the type and on 11 paratypes, ranging in length from 38 to 163 $\mathrm{mm}$ : Head 4.2 to 4.6 ; depth 10 to 12.5 ; lateral scutes 28 or 29 . Snout 2.1 to 2.4 in head; eye 5 to 8 ; interorbital 4 to 5.1 ; pectoral 1.3 to 1.4. Abdominal plates 3 to 7 . The color is described in the type (standard length $154 \mathrm{~mm}$.) as "brownish above, lighter below, the back crossed by six darker bars, the first on nape, indistinct, the second at base of dorsal, the rest approximately equidistant on the remainder of the body. All fins yellowish with dark spots, anal with fewer and lighter ones."

The smaller paratypes, ranging in length from 38 to $94 \mathrm{~mm}$., are described as similar in color, but darker, tending to be "Vandyke brown" instead of tan.

This species is known only from the type material of which Breder said (1927, p. 110): “Known only from the Rio Chucunaque and its 
confluents.... Most frequently taken in pools in the dry beds of evaporating side streams."

Sturisoma Swainson.

Sturisoma Swainson, Nat. Hist. Fish., Amph. Rept., 2, p. 304, 1839-type Loricaria rostrata Spix.

The above name has replaced Oxyloricaria Bleeker (1863) used in our earlier work (1916, p. 261), on the basis of priority.

Sturisoma panamensis (Eigenmann and Eigenmann).

Loricaria panamensis Eigenmann and Eigenmann, Proc. Calif. Acad. Sci., (2), 2, p. 34, 1889 - Panama.

Oxyloricaria panamensis Meek and Hildebrand, Field Mus. Nat. Hist., Zool. Ser., 10, p. 261, 1916.

Breder (1927, p. 113) recorded 22 specimens from the Chucunaque Basin. Meek and Hildebrand (1916, p. 261) had reported the species common in the Rio Tuyra, but rare in the Bayano (type locality).

The general range as given by Eigenmann (1922, p. 94) extends from the Bayano and Tuyra basins (Pacific slope) in Panama, through both slopes of Colombia to western Eucador.

Sturisoma citurensis (Meek and Hildebrand).

Oxyloricaria citurensis Meek and Hildebrand, Field Mus. Nat. Hist., Zool.

Ser., 10, p. 82, 1913-Rio Cupe, Cituro; p. 262, pl. 13, 1916.

Breder (1927, p. 113) recorded seven examples from the Chucunaque Basin. We (1916, p. 262) reported it abundant in the Rio Tuyra, but rare in the Bayano. Its distribution, so far as known, is limited to the basins of the Bayano and Tuyra of the Pacific slope of Panama.

\section{Family CALLICHTHYIDAE}

Hoplosternum punctatum Meek and Hildebrand.

Hoplosternum punctatum Meek and Hildebrand, Field Mus. Nat. Hist., Zool. Ser., 10, p. 264, pls. 14 and 15, 1916-Rio Marte Arnade, near Panama City.

Described in our earlier work from four specimens taken in the Rio Marte Arnade, about six miles east of Panama City. Since that time Breder (1927, p. 107) has reported 183 specimens, 30 to $66 \mathrm{~mm}$. long, from the Rio Chucunaque, near Yavisa, where the species seems to be common, though not seen by us in the Rio Tuyra. There is now at hand one additional specimen, $60 \mathrm{~mm}$. long, seined in a swamp at the La Jagua Hunting Club, about 15 miles east of Panama City. This specimen conforms well with the type material from the Rio Marte Arnade, except that the origin of the dorsal seems rather farther back, being equidistant from tip of snout and 
the beginning of adipose, wherein it conforms more nearly with Breder's specimens from the Tuyra drainage.

It is known only from the specimens mentioned in the foregoing paragraph, taken in a Pacific coastal stream and swamp not far from Panama City and in the Tuyra Basin. A closely related species, H. magdalenae, occurs in the Atlantic drainage in Colombia.

\section{Family ASTROBLEPIDAE}

The above name is substituted for Cyclopidae in our earlier work (1916, p. 265) for reasons stated in the account of the genus Astroblepus. A single genus with one species is known from Panama.

Astroblepus Humboldt.

Astroblepus Humboldt (in Humboldt and Bonpland), Recueil d'observations de zoologie et d'anatomie comparée faites dans l'Océan Atlantique, dans l'intérieur du nouveau continent et dans la Mer du Sud, pendant les années 1799, 1800, 1801, 1802, et 1803, 13, 48 pages, 7 pls.; Pt. 4, 1805, Mémoire sur l'Eremophilus et l'Astroblepus deux nouveaux genres de l'ordre des Apodes, par M. de Humboldt, p. 37 (type Astroblepus grixalvii). ${ }^{1} \quad$ The accounts of Astroblepus and A. grixalvii appear also in the Philosophical Magazine (London), without reference to the earlier work, 24, February to May, 1806, Art. 59, pp. 329 to 333, Memoir on the Eremophilus and Astroblepus, two new Genera of the Order Apodes. By M. de Humboldt. The account of Astroblepus is given on page 331 and a drawing of $A$. grixalvii appears on pl. 7, which has the same number as the one in the earlier work published in Paris.

The name given above, following Eigenmann (1922, p. 51), replaces Cyclopium in our earlier work (1916, p. 265). Eigenmann stated: "The mountain cat-fishes, hitherto known chiefly under the names Cyclopium and Arges, are considered here under the above generic name. Astroblepus was described by Humboldt as lacking ventrals, and has not been recognized since the publication of the original description, based on 'pescado negro' of Popayán.

"Posada, a Colombian naturalist (cf. his Estudios Cientificos, 1909), made a special effort to secure such a fish lacking ventrals, but did not find any, although many specimens were examined.

1 The book cited above is volume 13 of a general work consisting of 24 volumes published in Paris from 1805 to 1837 , entitled, Voyage aux regions equinoxiales du nouveau continent, fait au 1799-1804, etc., par Frederich Heinrich Humboldt et A. J. A. Bonpland. A second edition of the volume on Zoology, etc. (13), was published in Paris in 1811, wherein an account of Astroblepus appears in volume 1, page 19 . 
"Likewise in our collections, numbering hundreds of individuals, no specimens lacking ventrals are to be found. It seems, therefore, that the lack of ventrals in the figure of Humboldt is due to a mistake of the artist. Humboldt's name must stand as the earliest designation of these fishes."

The acceptance of this earlier name necessitates also the change of the family name from Cyclopidae to Astroblepidae.

\section{Astroblepus longifilis (Steindachner).}

Arges longifilis Steindachner, Denkschr. Akad. Wiss. Wien, 46, p. 19, pl. 5, fig. 3, 1882-Rio Huambo, Rio Totora, northern Peru.

Eigenmann (1922, p. 54) synonymized Cyclopium pirrense Meek and Hildebrand (1916, p. 265) with the above. Breder (1927, p. 105) reported seven specimens from the "Rio Sucubtí, in the creek at the Indian village, above the falls," Chucunaque Basin. In Panama this species has been reported only from the Rio Tuyra drainage. According to Eigenmann (1922, p. 54) this species ranges from the Rio Tuyra in eastern Panama to Peru, occurring in some places on both slopes.

\section{Family PYGIDIIDAE}

Prior to the work of Behre (1928) a single species of this family was known from Panama, which was reported only from the Rio Tuyra drainage.

\section{Pygidium septentrionale Behre.}

Pygidium septentrionale Behre, Ann. Carnegie Mus., 18, p. 309, pl. 18, 1928 Quebrada Solão, tributary to the Rio Chiriquí del Tire, near Caldera, western Panama.

No specimens have been seen by me. I quote from the original description.

"Head as broad as long; distance from chin to nearest point of gill, half the width of head. Length of head 6 to nearly 7 in length to base of caudal. Diameter of eye 3 in interocular width. Maxillary barbels reaching to origin of pectorals or shorter. Teeth conical, sharply pointed. Dorsal, caudal, and anal fins truncate. Pectoral filament short. Origin of dorsal above or a little in advance of vent and equidistant from tip of caudal and preopercle; distance from caudal nearly 2 in its distance from snout. Last dorsal ray over anal, but not over last. Origin of ventrals nearer tip of pectoral filament than caudal. Color slate inclining to brownish, mottled, especially below. Belly also dark." 
This species is known from 12 specimens, ranging in length from 69 to $110 \mathrm{~mm}$., secured by Dr. Behre in the Rio Chiriquí del Tire, in the vicinity of Caldera, at an altitude of about 4,000 feet.

Apparently the head is shorter and broader than that of striatum, being at least as broad as long, and its length is contained 6 to nearly 7 times in the standard length. The origin of the anal is farther forward with respect to the dorsal, as its origin is in advance of the last ray of the dorsal, whereas in striatum the origin of this fin is under or behind the last ray of the dorsal. $P$. septentrionale seems to be plainer in color, being slate to brownish and mottled, especially below. $P$. striatum is light olive and has a dark lateral band, and sometimes one additional one above and below the one along the middle of the side. These bands are sometimes more or less broken up into spots. The larger individuals have black spots on the back and sometimes on the lower parts also.

\section{Pygidium striatum Meek and Hildebrand.}

Pygidium striatum Meek and Hildebrand, Field Mus. Nat. Hist., Zool. Ser., 10, p. 78,1913 ; p. 266, 1916-Rio Cana, Cana, Panama.

This was the only species of the genus and family known from Panama, until Behre (1928, p. 309) described $P$. septentrionale from western Panama, where she also took one specimen of $P$. striatum. Previously, the last-mentioned species was known only from the type material from a small mountain stream at Cana in the upper part of the Rio Tuyra Basin. Dr. Behre took the fish at an elevation of about 4,000 feet.

According to Eigenmann (1922, p. 64) this species occurs also on both slopes of the mountains of Colombia. Although the species has not been taken in central Panama, where the elevation probably is too low, the general range apparently extends from western Panama into Colombia.

\section{Family CHARACINIDAE}

The members of this family are very numerous, ranging from the Rio Grande in Texas to Argentina and Peru. They are most abundant, however, in the equatorial parts of South America and become comparatively few north of the Isthmus of Panama. Some of the species grow large and are of value as food fishes, but many of them are small. The shape of the body varies from short and deep and strongly compressed, to long and slender or even pike-like. Scales are present on the body, but not on the head; the upper jaw anteriorly is formed by the premaxillaries, and laterally by the maxillaries; teeth 
various, often strong, and rarely wanting (as in Curimatus); dorsal fin small, without spines; an adipose fin is usually present (wanting in Hoplias).

In Panama the species have various names, as shown subsequently. In general the large species (Brycon) are called "sábalo," that is, herring, and the small species are mostly called "sardina," that is, sardines.

One genus, Characidium, has been added to the fauna of Panama since the publication of our earlier (1916) general work. A description is offered subsequently.

Characins are decidedly fewer in western than in central and eastern Panama. Dr. Behre (1928) secured only five genera, namely, Brycon, Astyanax, Bryconamericus, Hyphessobrycon, and Roeboides (including nine species), in western Panama, whereas these and 14 others (including 32 species) are known from the central and eastern sections of the republic. It seems evident, then, that many of the genera have their northernmost limit of distribution in central and eastern Panama. In fact, four genera, namely, Apareiodon, Phanagoniates, Hemibrycon, and Characidium, have been found no farther north (west) than the Tuyra Basin.

\section{Curimatus Oken.}

The members of this genus are widely distributed, ranging from Panama to Argentina and Peru. One species is known from Panama. The genus is characterized by the elongate robust body; the small mouth, which is without lips and without teeth; the complete lateral line; well-developed adipose fin; and the very long intestine.

\section{Curimatus magdalenae Steindachner.}

Curimatus magdalenae Steindachner, Denkschr. Akad. Wiss. Wien, 29, p. 50, 1878-Rio Magdalena; Meek and Hildebrand, Field Mus. Nat. Hist., Zool. Ser., 10, p. 269, 1916.

Specimens were secured in 1935 and 1937 on the Pacific slope east of Panama City at the La Jagua Hunting Club, in the Rio Tapia, and in the Rio Cabra.

Breder $(1927$, p. 113) recorded specimens from several places in the Chucunaque Basin.

Known from the Pacific slope of Panama, from the Rio Chorrera to the Rio Tuyra; also from the Atlantic slope of Colombia (Atrato and Magdalena basins) and southward into Venezuela. Although it has been taken by us on both sides of the Canal Zone, we have not found it within the Zone. This fish is herbivorous, as suggested by 
the very long intestine. It usually lives in quiet shallow water, which at times is very warm.

Apareiodon dariensis (Meek and Hildebrand).

Parodon dariensis Meek and Hildebrand, Field Mus. Nat. Hist., Zool. Ser., 10 , p. 83,1913 - Rio Cupe, tributary of the Tuyra.

Apareiodon dariensis Meek and Hildebrand, Field Mus. Nat. Hist., Zool. Ser., 10, p. 271, pl. 17, 1916.

Originally described from three specimens taken in the Rio Cupe, tributary to the Rio Tuyra. Breder.(1927, p. 114) recorded a fourth specimen from the Rio Chucunaque from slightly above the mouth of the Rio Chiatí. He, also, secured a second species of the genus, a description of which appears herewith.

A. dariensis remains known only from the Tuyra Basin.

\section{Apareiodon compressus Breder.}

Apareiodon compressus Breder, Amer. Mus. Nat. Hist., Nov., No. 180, p. 4, figs. 3, 4, 1925; Bull. Amer. Mus. Nat. Hist., 57, p. 115, figs. 5, 6, 1927Rio Tuquesa, Chucunaque Basin, Darien, Panama.

This species is known from a single specimen, $23 \mathrm{~mm}$. long, which has not been seen by me. The following description is condensed after Breder.

Head 3.2, depth 3.9, D. 11, A. 9, scales 36 . Body elongate, somewhat compressed; dorsal profile convex; snout bluntly pointed, not much in advance of mouth, 4.4 in head; eye 3; interorbital 3.1; mouth very small, inferior; lower jaw toothless; upper jaw with large, close-set overlapping teeth, wide at tips, with slightly rounded pectinate margins; lateral line straight; dorsal fin inserted in advance of ventrals, its origin about midway between snout and base of caudal; anal fin small, shorter than head, its origin nearer to base of caudal than to base of ventrals; ventral fins broad, with 9 rays, reaching beyond vent; pectorals broad, with 14 rays, not reaching ventrals.

Color only slightly darker above than below; sides with a dark band, following lateral line; base of caudal with an elongate black spot; nape with a dark triangular area, connected with a median dark line extending to dorsal fin. Dorsal and caudal slightly dusky; other fins plain.

This species differs prominently from the only other one (dariensis) of the genus known from Panama, in the much shorter and less strongly projecting snout, and in color. In dariensis the snout is pointed, much in advance of the mouth, and is contained in the head 2.8 to 3 times. The color is dark brown above, the sides have 
2 more or less broken black bands, and the dorsal and caudal lobes are prominently barred with black.

\section{Characidium Reinhardt.}

Small or minute fishes, elongate and generally subcylindrical in form. The jaws are provided with a single series of conical or tricuspid teeth; no frontal fontanel, but a small circular occipital one; lateral line complete; gill membranes free from the isthmus; adipose fin present.

Known from Panama from a single species, described by Breder $(1925$, p. 5). Therefore, it is not included in the general work on the fresh-water fishes of Panama by Meek and Hildebrand (1916). The species of the genus are described by Eigenmann (1922, p. 121) as living like and resembling Etheostoma (the darters) of North America.

\section{Characidium marshi Breder.}

Characidium marshi Breder, Amer. Mus. Nat. Hist., Nov., No. 180, p. 5, fig. 5, 1925; Bull. Amer. Mus. Nat. Hist., 57, p. 115, 1927-Rio Sucubtí, Chucunaque Basin, Darien, Panama.

This species is known only from the type material, consisting of eleven specimens ranging in length from 15 to $44 \mathrm{~mm}$. The specimens have not been seen by me. The following description is condensed after Breder.

Head 3.3 to 3.8 ; depth 3.9 to 4.7 ; D. 11 ; A. 7 to 9 ; scales 31 to 35 , in front of dorsal 10 or 11 , across peduncle 5 to 7 . Body elongate, subcylindrical; dorsal profile convex; snout bluntly pointed, 4 to 4.3 in head; eye 3.9 to 4.7 ; mouth subterminal; maxillary reaching eye; teeth conical in upper jaw, weakly tricuspid in lower jaw; lateral line weakly developed, complete, slightly decurved; dorsal fin inserted in advance of ventrals, about equidistant from anterior margin of eye and tip of adipose; adipose over last anal rays; pectorals reaching ventrals, the outer rays thickened, the fins equal to length of head.

Color dark above, paler below; side with a dark band crossed by 7 vertically elongate spots, the last one extending somewhat on middle caudal rays, encompassing a small black dot. Dorsal dusky, crossed by a dark bar on basal half; other fins plain dusky.

This is the only species of the genus known from Panama.

Phanagoniates macrolepis (Meek and Hildebrand).

Roeboides macrolepis Meek and Hildebrand, Field Mus. Nat. Hist., Zool. Ser., 10, p. 84, 1913-Rio Cupe, Tuyra Basin.

Phanagoniates macrolepis Meek and Hildebrand, Field Mus. Nat. Hist., Zool. Ser., 10, p. 272, 1916. 
Since the publication of our earlier (1916) work, Breder has recorded this fish from the Rio Chico and the Rio Sucubtí in the Chucunaque Basin.

This species is known from the Tuyra Basin in Panama and the Atrato in Colombia. In the Tuyra it seems to be rather rare.

\section{Compsura Eigenmann.}

The minute fishes of this genus (the Panama representative apparently being less than $50 \mathrm{~mm}$. in length) differ from related forms in the peculiarly enlarged scales on the base of the lower lobe of the caudal fin in the male. The genus is further characterized by having a single series of multicuspid teeth in each jaw, and by having an incomplete lateral line, present on only about 5 to 13 scales. A conspicuous black caudal spot is present in the single species occurring in Panama waters.

Compsura gorgonae (Evermann and Goldsborough).

Cheirodon gorgonae Evermann and Goldsborough, Proc. Biol. Soc. Wash., 22, p. 99, figs. 1, 3, 1909-Gorgona, Canal Zone.

Compsura gorgonae Meek and Hildebrand, Field Mus. Nat. Hist., Zool. Ser., 10, p. 274, 1916.

This is the smallest of the characins ("sardinas") occurring in the local waters. No individuals exceeding a length of $40 \mathrm{~mm}$. have been found. Although it occurs on both slopes of central Panama, it does not seem to be numerous there. Specimens were secured in 1935 and 1937 in an abandoned reservoir at Mount Hope; in Gatun Lake at Gatun and Barro Colorado Island; in Madden Lake; in a creek tributary to Gatun Lake on Madden Dam Road; in the Rio Cocoli, tributary to Miraflores Lake; in the Rio Cabra; and in a swamp at the La Jagua Hunting Club. The three localities last named are on the Pacific slope. As this species occurs naturally on both slopes of Panama, it is not possible to determine from the specimens collected whether it uses the Pedro Miguel Locks as a passageway between Gatun Lake (Culebra Cut) and Miraflores Lake.

The rather short deep compressed body, the incomplete lateral line (present on only about 5 to 13 scales) and the large black spot on the base of the caudal fin are recognition marks. The single series of multicuspid teeth in each jaw, and peculiarly enlarged scales on the base of the lower lobe of the caudal fin are other distinguishing characters. The following proportions and counts are based on seven specimens unless otherwise stated: 
Head 3.75 to 4.3 ; depth 2.6 to 3 ; D. 10 ; A. 17 to 20 ; P. 10 to 12 ; scales 4 or $5-30$ to $34-3$ or 4 ; vertebrae 12 or $13+17$ or 18 (two specimens examined). Snout 4.8 to 6 in head; eye 2.7 to 3.2 ; interorbital 3.2 to 4 . Distance from snout to dorsal 1.8 to 2 in standard length; base of anal 4 to 4.9 ; pectoral 4.6 to 5 .

This fish was recorded from the upper Rio Chucunaque by Breder (1927, p. 117). Its range, so far as known to date, is limited to both slopes of central Panama, and the Tuyra Basin in eastern Panama.

\section{Pseudocheirodon Meek and Hildebrand.}

This genus, of which a single species is known, is characterized by the compressed body with elevated back; the broad second suborbital which covers nearly the entire cheek; the single series of premaxillary and mandibular teeth with expanded tips that overlap more or less; the incomplete lateral line, usually present on only 8 to 12 scales; and the normally scaled base of caudal and non-protruding interhaemal spines in both sexes.

\section{Pseudocheirodon affinis Meek and Hildebrand.}

Pseudocheirodon affinis Meek and Hildebrand, Field Mus. Nat. Hist., Zool. Ser., 10, p. 275, pl. 18, 1916.

In 1935 and 1937 specimens were collected in an abandoned reservoir at Mount Hope; in the upper end of Gatun Lake (Chagres River), not far from Madden Dam; in Miraflores Lake, in swamps at the La Jagua Hunting Club; and in several small coastal streams on the Pacific slope, including the Pacorá, the Cabra, and a small stream near Campaña. As this species was common to both slopes before the Canal was opened, it cannot be determined from the collections whether it uses the Pedro Miguel Locks as a passageway.

$P$. affinis seldom exceeds a length of $55 \mathrm{~mm}$. It is most readily recognized by the single series of teeth on the premaxillaries; the incomplete lateral line, which is usually present on only 8 to 12 scales; the normally scaled base of caudal, and non-protruding interhaemal spines in both sexes; and the large black caudal spot, followed by a whitish area on both lobes of the caudal fin.

The following counts and proportions are based on seven specimens (unless otherwise stated), ranging in length from 27 to $50 \mathrm{~mm}$.:

Head 3.6 to 4.3 ; depth 2.6 to 2.9 ; D. 10 or 11 ; A. 22 or 23 ; P. 10 or 11 ; scales 5 or 630 to $33-5$; vertebrae 12 or $13+16$ or 17 (two specimens examined). Distance from snout to dorsal 1.8 to 2 in standard length; base of anal 3.4 to 4 ; pectoral 4.5 to 5.3. Snout 5.1 to 5.6 in head; eye 2.8 to 3.2 ; interorbital 2.8 to 3.5. Premaxillary 
teeth in a single series, consisting of 10 to 12 multicuspid teeth expanded at tips, with none of the cusps especially enlarged; maxillary with 2 low multicuspid teeth; mandible with 10 or 12 broad multicuspid teeth with expanded tips that overlap more or less.

Breder (1927, p. 118), who reported many specimens from several places in the Chucunaque Basin, remarks concerning their occurrence, "Taken only above the head of tide, becoming more abundant as the headwaters were approached, generally being found in large schools in quiet and comparatively deep pools."

This species is known from both slopes of central Panama and the Tuyra Basin of eastern Panama.

Gephyrocharax Eigenmann.

This genus is recognized by the strongly compressed body; the strongly rounded ventral outline; the long anal (consisting of 29 to 32 rays in Panama species); the posteriorly inserted dorsal fin, which has its origin behind that of the anal; the presence of two series of teeth on the premaxillaries; the broad second suborbital covering the entire cheek; and the peculiar "spur" formed by the lower free fulcra of the caudal in the male.

The differences among the three species taken in Panama are shown in the accompanying parallel.

Distinguishing Characters of Panama Species

OF GEPHYROCHARAX

atricaudata

intermedius

Profile from snout to oc- Profile as in atricaudata. Profile from tip of snout ciput slightly convex; a definite off-set at mouth.

Gape and lower lip notably Gape as in atricaudata. below dorsal outline of head; not entering into the general profile of head.

Lower lip thin.

Pectoral fin long, generally reaching toor beyond middle of ventral, 3.7 to 4.25 in standard length, average in 21 specimens 3.9.

Dorsal fin low, failing to reach adipose by 1 or 2 rows of scales if deflexed.

Caudal spot not followed by a whitish area on each lobe of the fin. Outer rays of caudal black. to occiput straight, no off-set at mouth.

Gape and lower lip on level with upper lip; entering into the nearly straight dorsal profile of head.

Lower lip as in atricaudata.

Lower lip broader and more or less fleshy.

Pectoral shorter, gener- Pectoral long, as in atricaually failing to reach data, 3.6 to 4.1 in standmiddle of ventral, 4 to 4.5 in length, average in 19 specimens 4.25 . ard length, average in 21 specimens 3.78 .

Dorsal fin as in alricaudata.

adipose if deflexed.
Caudal spot followed by Color as in intermedius.

a whitish area on each

lobe of the fin. Outer rays of caudal not black. 
Gephyrocharax atricaudata (Meek and Hildebrand).

Gephyrocharax atricaudata Meek and Hildebrand, Field Mus. Nat. Hist., Zool. Ser., 10, p. 68, 1912-Rio Frijoles, Canal Zone; p. 277, 1916.

Many specimens were collected in 1935 and 1937. A particularly fine lot was taken in the Rio Cocoli, a short distance from Miraflores Lake, but none in the lake itself. Some of these specimens are larger than any previously seen, ranging upward to $65 \mathrm{~mm}$. in length. The species was secured also in Gatun Lake near Gatun; a short distance below Madden Dam; in the present mouth of the Rio Boquerón, above Madden Lake; in a small stream, formerly a tributary of the Chagres, on Madden Dam Road; in an abandoned reservoir at Mount Hope; in a swamp at the La Jagua Hunting Club; and in the Rio Pacorá and the Rio Cabra on the Panama City-Chepo Road.

G. atricaudata occurs on both slopes of central Panama, but is replaced by two other species of the genus in the coastal streams between Campaña and La Venta. As this fish naturally inhabits both slopes of central Panama it is impossible to determine from specimens whether it uses Pedro Miguel Locks (wherein it was not found) as a passageway, though that is not improbable.

This species was quite accurately described by Meek and Hildebrand (1916, p. 277), though no mention was made of the seemingly somewhat longer pectoral fin than in intermedius, with which it is very closely related in structure. The following proportions and counts are based on eight specimens, unless otherwise stated, ranging in length from 43 to $65 \mathrm{~mm}$.:

Head 4.2 to 4.5 ; depth 2.8 to 3 ; D. 9 ; A. 31 or 32 ; P. 10 ; scales $7-38$ to $41-5$; vertebrae 10 or $11+24$ or 25 (three specimens examined). Snout 3.8 to 4.6 in head; eye 3 to 3.4 ; interorbital 2.7 to 3.1 . Distance from snout to dorsal 1.5 to 1.7 in standard length; base of anal 2.8 to 3 ; pectoral 3.7 to 4.25 (21 specimens examined).

Breder (1927, p. 125), who reported this species from several places in the Chucunaque Basin, found considerable variation in color, showing some intergradation with $G$. intermedius. No intergradation seems to exist among the material from central Panama. A difference in the proportionate length of the pectoral fins in the two species is shown in the parallel on page 252 .

G. atricaudata is common in the Chagres Basin, and on the Pacific slope from the Canal Zone eastward to the Tuyra Basin.

Gephyrocharax intermedius Meek and Hildebrand.

Gephyrocharax intermedius Meek and Hildebrand, Field Mus. Nat. Hist., Zool. Ser., 10, p. 278, 1916-Rio Chame. 
This species was described from the Rio Chame, where at that time (1911) G. whaleri was not secured. On March 10, 1937, while en route from Balboa to La Venta several stops were made for the purpose of collecting specimens in a half dozen or more small coastal streams crossing the National Highway between Campaña and La Venta. The specimens from the different streams were not kept as separate collections. Of this species 23 were taken. Whether these specimens are all or in part from the Rio Chame, the type locality, cannot be stated. Neither is it known whether any of the new species, whaleri, herein described, were taken in the Rio Chame, as the species was not recognized in the field.

The original description (Meek and Hildebrand, 1916, p. 278) of this species is essentially correct. However, it was not pointed out that the pectoral fins apparently are slightly shorter than in atricaudata. Nor was it stated that the caudal spot is followed by a whitish area on each lobe of the fin. Unless otherwise stated the following proportions and counts are based on six specimens taken March 10, 1937:

Head 4 to 4.3 ; depth 3.1 to 3.4 ; D. 9 ; A. 29 to 31 ; P. 9 or 10 ; scales $7-36$ to $40-5$; vertebrae $12+22$ (one specimen examined). Snout 4.3 to 4.7 in head; eye 2.8 to 3.5 ; interorbital 2.6 to 3.2 ; distance from snout to dorsal 1.6 in standard length; base of anal 2.8 to 3.1 ; pectoral 4 to 4.5 (19 specimens examined).

This fish inhabits the Rio Chame and probably neighboring coastal streams.

Gephyrocharax whaleri sp. nov.

Type from Rio Chame or a near-by stream, Pacific slope, Panama. No. 106513 United States National Museum. Total length $53 \mathrm{~mm}$., standard length $40 \mathrm{~mm}$.

Description of the Type.-Head 4.2; depth 3.1 ; D. 9 ; A. 32 (including 3 undivided rays); P. 11; scales 6-35-5.

Body strongly compressed; the ventral outline very convex anteriorly, the dorsal profile straight and nearly horizontal from snout to occiput, gently convex posterior to occiput; snout shorter than eye, 4.1 in head; eye 3; interorbital 2.7; mouth strongly oblique, superior, the lower lip in advance of the upper one, entering into the general dorsal profile; maxillary ascending almost vertically close in front of eye, scarcely extending beyond anterior margin of orbit; lower lip rather broad and fleshy; premaxillary teeth in 2 series, the outer series incomplete and smaller than inner series; maxillary with 
2 small teeth; mandible with a single series of teeth, enlarged on anterior part of jaw with abruptly smaller ones on each side; gill rakers very short, mere points, 12 on lower limb of first arch; lateral line strongly decurved; scales moderate, the series only fairly regular; dorsal fin inserted posteriorly, equidistant from base of caudal and shoulder spot, distance from snout to dorsal 1.6 in standard length, the fin high with longest rays reaching adipose if deflexed; adipose over base of last rays of anal; caudal fin rather deeply forked; anal fin long, its origin fully an eye's diameter in advance of dorsal, its base 3 in standard length; ventrals moderate, reaching origin of anal;

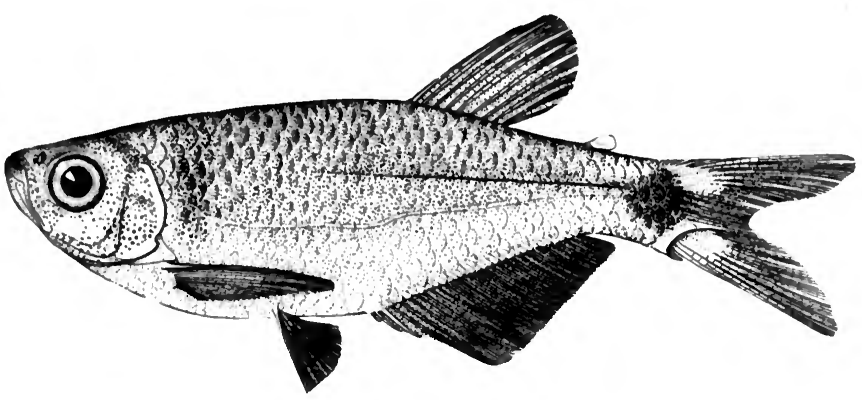

FIG. 2. Gephyrocharax whaleri sp. nov. Type, male, $53 \mathrm{~mm}$. long. (From drawing by Louella E. Cable.)

pectorals long, reaching somewhat beyond mid-length of ventrals, 3.6 in standard length.

Color greenish with silvery luster above, plain silvery below. Base of caudal with a prominent spot, followed by a whitish area, the black not extending on fin; a prominent vertically elongate shoulder spot present, extending nearly from the nape to behind base of pectoral; fins plain colorless except for dusky points.

Variations noticed in the paratypes are as follows: Head 3.75 to 4.2 ; depth 3 to 3.2 ; A. 30 to 32 (including undivided rays); P. 10 or 11 ; scales 6 or $7-35$ to $38-5$, before dorsal 17 to 20 ; vertebrae 10 or $11+23$ or 24 (three specimens examined). Snout 3.7 to 4.4 in head; eye 2.8 to 3.4 ; interorbital 2.7 to 3.2 . Distance from snout to dorsal 1.5 to 1.6 in standard length; base of anal 2.8 to 3 ; pectoral 3.6 to 4.1 (21 specimens measured). 
The teeth are seen with difficulty without removing the jaws. Those in the upper jaw are in 2 series. The outer series is irregular and consists of 2 to 4 small tricuspid teeth on each side, with none in front of the 2 anterior (middle) teeth in second row. The second series is regular and the teeth are larger, with 4 or 5 teeth, each with 3 to 5 cusps. Maxillary anteriorly with 2 very small tricuspid teeth. Mandible with 4 enlarged teeth on each side, followed by abruptly smaller ones. The enlarged teeth with 3 to 5 cusps, the middle cusp long and pointed.

This species is represented in the collection by 50 specimens (including 23 males), ranging in length from 26 to $65 \mathrm{~mm}$. These specimens are probably not all from one stream, as collections of fish were made in the Rio Chame and several smaller near-by coastal streams crossing the National Highway between Campaña and La Venta. The several collections were not kept separate.

This species agrees in color with intermedius, its nearest relative inhabiting the Rio Chame and probably other near-by streams. It differs from that species in the more nearly vertical mouth and thicker lower lip, which extends upward and enters into the straight dorsal profile of the head, whereas the lower lip in intermedius is lower than the upper one (as in atricaudata), causing a decided break at the mouth in the general dorsal outline of the head. The thickened lower lip seems to be normal in G. whaleri, and has not been noticed in any of the many specimens of the other species of the genus examined, though in some other genera (Astyanax and Bryconamericus) of characins it does not seem to have any specific significance. The dorsal fin is notably higher (in both sexes) in whaleri than in the other local species of the genus, reaching to or a little beyond the origin of the adipose if deflexed, whereas in intermedius and atricaudata it fails to reach the adipose by 1 or 2 rows of scales. The specific differences among the three local species of Gephyrocharax shown in the accompanying parallel.

I take pleasure in naming this species for my friend, Fred Whaler of Balboa, Canal Zone, who is an ardent angler as well as a student of fishes, and who rendered valuable assistance when the specimens were taken.

Astyanax Baird and Girard. Sardinas de Montaña.

This species of this genus are small, compressed, rather deepbodied fishes, the depth generally being contained, more than 2 times in the length to the base of caudal. The teeth in the premaxillaries 
are in 2 even rows, each row with 8 teeth in Panama species. The lower jaw has strong teeth (8 in Panama species) anteriorly, followed on each side by abruptly smaller ones. The maxillary has a few ( 2 in Panama species) small teeth at its juncture with the premaxillary, or none. The second suborbital is rather narrow, not coming in contact with the lower limb of the preopercle, and it leaves a small naked triangular area at its juncture with the first suborbital. The lateral line is complete, and scales (all normal) do not extend far on the base of the caudal. The vertebrae in Panama species are $14+17$ or 18. Five species are known from Panama, one of them being new and herein described.

\section{Astyanax fasciatus (Cuvier).}

Chalceus fasciatus Cuvier, Mem. Mus. Paris, 5, p. 352, 1819-Brazil.

Astyanax fasciatus Meek and Hildebrand, Field Mus. Nat. Hist., Zool. Ser., 10, p. $280,1916$.

Specimens recently collected in central Panama, as well as those collected there and in eastern Panama by us in 1911 and 1912, differ prominently from specimens of the extremely abundant $A$. ruberrimus in the absence of a black caudal spot. A. fasciatus also differs, so far as Panama material at hand is concerned, in being slightly deeper, in having a larger number of longitudinal rows of scales, and in reaching a somewhat larger size. Both species vary considerably in depth, causing the proportional measurements to overlap. An average difference exists, however, as in 26 specimens of $A$. fasciatus measured the range of the depth in standard length is 2.2 to 2.7, and the average 2.42 . In 67 specimens of ruberrimus the range is 2.25 to 3.1 , and the average 2.66 . A. fasciatus apparently nearly always has 8 rows of scales between the lateral line and the base of the first dorsal ray, and 7 between the lateral line and the base of the ventral. In 27 specimens examined two specimens differ, one having 7 rows above the lateral line, and another having 6 rows below it. In 30 specimens of ruberrimus constantly 7 rows above the lateral line and 5 or 6 (usually 6 ) below it were counted. Specimens of fasciatus up to $150 \mathrm{~mm}$. in length were taken, but none of ruberrimus exceeding $110 \mathrm{~mm}$.

Breder (1927, p. 122) found it difficult to separate his specimens from the Rio Chucunaque into two species and expressed doubt concerning the validity of fasciatus and ruberrimus. Eigenmann (1921, p. 306) placed the Panama specimens, identified by Meek and Hildebrand (1916, p. 280), as fasciatus, in the subspecies aeneus, which according to his key falls into the group having a dusky or 
black band extending to the end of the middle rays of the caudal fin. No such band is present in any of our Panama specimens. Behre (1928, p. 319) recorded A. aeneus costaricensis Meek from extreme western Panama (Atlantic slope). This subspecies apparently is a synonym of $A$. fasciatus a€neus as understood by Eigenmann. I am obliged to regard the identity of the Panama material from the Pacific slope with that of the Atlantic slope of western Panama and Costa Rica as very doubtful.

Specimens were collected in 1935 and 1937 at the La Jagua Hunting Club, in the Rio Pacorá and the Rio Cabrá, and in other small coastal streams along the Panama City-Chepo Highway. One fine specimen, $107 \mathrm{~mm}$. long, was taken in a creek, formerly tributary to the Rio Chagres, now flowing into Gatun Lake, not far from Madden Dam. As this species was not taken in the Atlantic drainage during the extensive collecting done on the Canal Zone and vicinity in 1911 and 1912, before the opening of the Canal, it seems probable that it has "migrated" through Culebra Cut from the Rio Grande Basin of the Pacific slope.

This species and its various subspecies or varieties, as now understood, range from Mexico through Panama and Colombia to Brazil.

Astyanax ruberrimus Eigenmann.

Astyanax ruberrimus Eigenmann, Indiana Univ. Studies, No. 18, p. 25, 1913 -Istmina, Atlantic slope, Colombia; Meek and Hildebrand, Field Mus. Nat. Hist., Zool. Ser., 10, p. 281, 1916.

The relationship of this very common species, inhabiting both slopes of Panama and Colombia, is discussed under $A$. fasciatus and A. kompi. It is most readily recognized by its large black caudal spot, which does not extend to the end of the caudal rays; and by the moderate number, namely 7 , of longitudinal rows of scales between the lateral line and the base of the first dorsal ray, and 5, or more commonly 6 , rows between the lateral line and the base of the ventral. It rarely exceeds a length of $100 \mathrm{~mm}$. (4 inches), the usual length being around $75 \mathrm{~mm}$. (3 inches).

Specimens were collected at the La Jagua Hunting Club, and in various Pacific slope streams along the Chepo Highway near Panama City; also, at Campaña in the Rio Capira, in several streams crossing the National Highway between Campaña and La Venta, and in a small stream along the road to El Valle, but not in El Valle. Many specimens were seined in the Rio Cocoli and Miraflores Lake. Others from the Pacific drainage are from Fort Kobbe, and Albrook Flying Field. In the Atlantic drainage this species was taken in the 
Rio Boquerón, above Madden Lake, and in Madden Lake; in some small creeks crossing Madden Dam Road; in Chillibrillo Cave (where this species and a catfish, Rhamdia wagneri, only were found); in Gatun Lake at Gatun, Gamboa, a short distance below Madden Dam, at Saddle Ridge, and Barro Colorado Island, and various places in the open lake; in abandoned reservoirs at Gatun and Mount Hope; and in running streams at Fort Sherman (Toro Point), and Cativa.

This species is common and may be seen and taken almost anywhere in streams, swamps, and lakes of central and eastern Panama. It is the most numerous of all fresh-water fishes of the Canal Zone, having become exceedingly abundant in Gatun and Miraflores lakes. A small piece of bread, banana, meat, or other food, thrown into the water, brings dozens of these little fish to the surface almost immediately. It is chiefly this species that nibbles at the bather if he remains quiet in the water for a few seconds.

The large notched teeth and short intestine suggest an animal diet. However, in addition to insects, crustaceans, and occasionally a small mollusk, much debris is generally present, some of which can often be identified as of vegetable origin. Other parts of the debris sometimes consist of small flakes of meat, no doubt from animals too large to swallow whole. The large rasping teeth are well suited to cutting bites of meat from other animals. For their size these little characins probably are no less ferocious than the distantly related piranhas (the man-eating fishes) of the Amazon and Orinoco rivers, and it is believed that they are responsible chiefly for the failure of the several introductions of food and game fishes in Gatun Lake by the United States Bureau of Fisheries.

As this species was common in both the Rio Chagres and Rio Grande basins before the opening of the Canal it is impossible to determine from the collections whether it uses the Pedro Miguel Locks as a passageway. However, as some of the other characins, and especially $A$. fasciatus, almost certainly at times do pass through the Pedro Miguel Locks, it seems probable that this common species likewise passes through them, though none was seen in the locks when dewatered during the writer's presence, February 20, 1937.

Charles M. Breder of the New York Aquarium, who has collected extensively in Panama, some years ago called my attention in correspondence to the fact, which I also had noticed, that nearly all adult ruberrimus from the Pacific slope have reddish fins, whereas those from the Atlantic have yellowish fins. In 1935 and 1937 I gave special attention to this difference in color. I failed to find adults 
in the Pacific slope without pink or red fins, but I did find some specimens on the Atlantic side that had them. For example, I caught several specimens in Gatun Lake at Gatun with reddish fins. It might be supposed that these fish had come through the Canal from the Pacific side. However, I also secured several specimens with reddish fins in an abandoned reservoir at Mount Hope and in a running stream at Cativa, localities entirely separate from the Canal. This rather usual difference in color, then, seems to be of no specific significance.

Breder (1927, p. 120) recorded many specimens from various localities in the Chucunaque Basin. He examined a large number of stomachs for food content and found about the same foods as those reported above for specimens from central Panama.

This very common fish of central and eastern Panama, according to Eigenmann (1922, p. 144) ranges into Colombia only on the Pacific slope. Dr. Behre (1928) did not report it from western Panama, and my record (1928, p. 83) based on specimens from the lagunas Verde, Grande, and Gulnar, Chiriquí, proves to be an error, as further study has shown that the fish belong to a distinct species, herein named A. kompi.

Astyanax kompi sp. nov.

Astyanax ruberrimus Hildebrand (not Eigenmann), Copeia, No. 168, p. 83, 1928.

Type from Laguna Gulnar or Grande, Volcán, Pacific slope, Panama. No. 106510 United States National Museum. Length $70 \mathrm{~mm}$. Also 46 paratypes, length 18 to $80 \mathrm{~mm}$.

Description of the type.-Head 3.8, depth 3.2, D. 10, A. 27, scales 35. Body compressed, moderately elongate; head short; snout blunt, notably shorter than the large eye, 4.4 in head; eye 3.1 ; interorbital 3 ; mouth small, jaws subequal; maxillary a little beyond anterior margin of pupil, forming an obtuse angle with the premaxillary, slightly longer than snout and a little shorter than eye; premaxillary teeth in 2 regular series, each with 8 teeth, those of the second series larger, all premaxillary teeth with 3 to 5 cusps; maxillary anteriorly with 2 small teeth; lower jaw with 8 strong teeth having 3 to 5 cusps, followed on each side by abruptly smaller teeth; gill rakers short, 12 on lower limb of first arch; lateral line complete, moderately decurved; scales rather large, 10 between dorsal and adipose, 6 complete rows of scales between the lateral line and base of anterior rays of dorsal, and an equal number between the lateral line and base of ventral; 
origin of dorsal not quite an eye's diameter nearer tip of snout than base of caudal; adipose over end of base of anal, rather more than half as far from base of caudal as from end of base of dorsal; caudal fin moderately forked, the lower lobe only slightly longer than the upper one, about as long as head; anal rather long, its base about equal to length of head, 3.8 in standard length, its origin just posterior to base of last ray of dorsal; ventral fins scarcely to origin of anal, inserted a little less than half an eye's diameter in advance of dorsal; pectoral failing to reach ventral by one row of scales, 1.2 in head.

Color mostly silvery; with a fairly distinct dusky lateral band, nowhere as wide as eye, ending in a prominent, elongate black caudal spot, with a slight indication of the black extending to end of middle

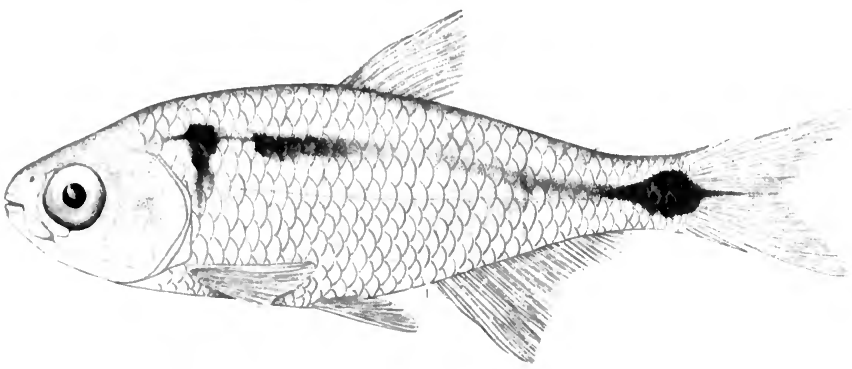

Fig. 3. Astyanax kompi sp. nov. Type, $70 \mathrm{~mm}$. long. (From drawing by Andrew Pizzini.)

caudal rays; humeral spot prominent, with a downward projection, extending on second row of scales below lateral line; a second less distinct spot somewhat less than an eye's diameter behind the first; opercle dusky; fins mostly translucent, without definite markings.

The variations noticed in the paratypes are as follows: Head 3.5 to 3.9 , depth 3 to 3.7 , D. 10 or 11 , A. 27 to 30 , scales 633 to $36-6$, vertebrae $14+17$ or 18 (four specimens dissected); snout 4 to 4.8 in head; eye 3 to 3.3 , interorbital 2.8 to 3.3 , pectoral 1.2 to 1.4 .

No variation in the number of teeth has been found. The exact shape of the 2 maxillary teeth cannot be seen without removing the maxillary for examination under the microscope. It then becomes evident that the first tooth has a long base with 6 or 7 cusps, and the second one, which is smaller, has 3 or 4 cusps. 
The origin of the dorsal, though nearly an eye's diameter nearer tip of snout than base of caudal in the type, is more usually about equidistant from these points in the paratypes. The base of the anal is equal to or a little longer than the head, 3.7 to 4.7 in standard length. In the young the ventrals reach the origin of the anal, and the pectorals to or a little beyond the base of ventrals. These fins do not reach quite as far in adults.

If the scales are counted in exactly the same place each time there is remarkably little variation. In fact, there are constantly 6 longitudinal series between the lateral line and the base of the anterior dorsal ray, and a like number between the lateral line and base of ventral, in 21 specimens examined.

The color is remarkably uniform in specimens of equal size. However, in the young the lateral band is proportionately narrower, and in the very young the second humeral spot is missing. The caudal spot does not occupy the entire width of the caudal peduncle, as in young $A$. ruberrimus. In life the fish were greenish above, sides and below bright silvery, and the fins mostly pinkish.

The fish were taken in part in Laguna Gulnar and in part in Laguna Grande (renamed Davis in honor of a former United States minister to Panama), the catches not being kept separate. This species is the only characin that was secured. It was abundant in both lakes at the time of my visit (February 7, 1935).

The lakes are at an elevation of about 4,500 feet, and supposedly occupy craters of extinct volcanoes. The temperature of the water at the surface, near shore, was $75^{\circ} \mathrm{F}$. in each lake in mid-afternoon on February 7, 1935.

The characin taken is close to A. ruberrimus, and specimens collected in these lakes by Fred J. Foster in 1924 were so recorded by me $(1928$, p. 83). However, a further study, based on a larger number of specimens, shows the Volcán specimens to differ sufficiently to be entitled to recognition as representatives of a distinct species which is apparently new. The specimens from Volcán are more slender, have larger eyes, and fewer rows of scales above the lateral line.

The range of the depth in the standard length in 34 Volcán specimens measured is 3 to 3.7 , the average for these specimens being 3.28 , whereas in 67 specimens of ruberrimus from various localities of both slopes of central Panama the range is 2.25 to 3.1 , with an average of 2.66. The measurements, therefore, overlap slightly. However, only four specimens of ruberrimus are slender enough to 
come within the range of the Volcan material. Usually the two species, then, may be separated at once by the difference in the depth of the body.

The number of longitudinal rows of scales above the lateral line is remarkably constant in both species. In 23 specimens from Volcán counted there are constantly 6 complete scales between the lateral line and the base of the first ray of the dorsal, whereas in 30 specimens of ruberrimus from various localities of central Panama there are constantly 7 . It is imperative that the scales be counted in exactly the same place in each species in order to show the difference of the single row mentioned.

The larger eye in the Volcán material is evident at once if specimens of equal size are compared, but cannot be well demonstrated by measurements of specimens of various sizes. In specimens ranging from about 50 to $80 \mathrm{~mm}$. in length the eye is contained in the head about 2.8 to 3.1 times in the Volcán specimens, and 3.2 to 3.9 times in Canal Zone material.

The writer takes pleasure in naming this 'species for the distinguished medical entomologist of the United States Public Health Service, W. H. W. Komp, who accompanied the author in his investigations in the Volcán region.

Astyanax nicaraguensis Eigenmann and Ogle.

Astyanax rutilus nicaraguensis Eigenmann and Ogle, Proc. U. S. Nat. Mus., 33, p. 23, 1907-Nicaragua.

This rather doubtfully distinct species is included because of a record by Behre (1928, p. 319), who listed it from some small streams on the Atlantic slope of extreme western Panama in the Province of Bocas del Toro.

This imperfectly understood species seems to differ from albeolus chiefly in the position of the dorsal fin, which has its origin about equidistant from the tip of the snout and the base of the caudal. It has 2 to 8 teeth on the maxillary, 27 to 32 anal rays, and 32 to 40 scales in the lateral series. The caudal band (not spot), as in albeolus, extends to the end of the middle rays of the caudal.

The range, as reported, extends from Nicaragua to extreme western Panama. The genus Astyanax of Central America seems to require much more study to determine the relationships and distribution of the species.

\section{Astyanax albeolus Eigenmann.}

Astyanax albeolus Eigenmann, Bull. Mus. Comp. Zool., 52, p. 97, 1908-Rio Machuca, Costa Rica. 
This species is included in the Panama fauna on the basis of a record by Behre. (1928, p. 319) who listed it from the Rio Chiriquí del Tire, near Caldera (Pacific slope), Chiriquí, Panama, with the remark: "These fishes seem to differ from Eigenmann's A. albeolus only in that the body is slightly less compressed and more shallow, and that the anal fin count is occasionally below the type."

It apparently differs from kompi, the nearest relative among Panama fishes, in the deeper body; smaller scales; the more anterior insertion of the dorsal, which begins more than an eye's diameter nearer to the tip of snout than to base of caudal; and in color, the black lateral band (not a black caudal spot) extending prominently to the end of the middle rays of the fin, wherein it also differs from other Astyanax from Panama, exclusive of nicaraguensis.

The following counts and proportions are from Eigenmann (1921, p. 290): Head 4.5; depth 2.66 ; D. 11 ; A. 26 to 30 ; scales $7-38-7$; eye equal to snout, 3.5 in head.

The species, prior to Dr. Behre's record, was listed only from Costa Rica.

\section{Bryconamericus Eigenmann. SARdinas de MontaÑa.}

This genus is close to Astyanax, from which it differs in having a broader second suborbital, which is in contact with the lower limb of the preopercle, and does not leave a small naked triangular area at its suture with the first suborbital. The teeth in the premaxillaries are in 2 series as in Astyanax, but the first series has 10 instead of 8 teeth (Panama species) and they are in an uneven row (at least in Panama species). On the maxillary, at its juncture with the premaxillary, there are 2 or 3 very small teeth with roundish base, whereas Astyanax from Panama have 2 small teeth in the same position, but each with a long base, the first one especially being very elongate. In Panama specimens of Bryconamericus, at least in emperador and zeteki, the vertebrae are a little more numerous, the formula being $15+20$ or 21 , whereas that for Astyanax is $14+17$ or 18 .

\section{Bryconamericus emperador (Eigenmann and Ogle).}

Astyanax emperador Eigenmann and Ogle, Proc. U. S. Nat. Mus., 33, p. 26, 1907-Empire, Canal Zone.

Bryconamericus emperador Meek and Hildebrand, Field Mus. Nat. Hist., Zool. Ser., 10, p. 283, 1916.

Specimens were secured in 1935 and 1937 in the upper part of Gatun Lake (near Madden Dam), at Barro Colorado Island, and in a small stream on Madden Dam Road, tributary to Gatun Lake. 
None were taken in Miraflores Lake, nor in the other waters sampled on the Pacific slope during the recent investigations. Meek and Hildebrand (1916, p. 284) remarked concerning the distribution: "It occurs on both slopes of Panama, and is always found in company with Astyanax ruberrimus, but much less abundant, except in the Rio Tuyra Basin where it outnumbers the latter." Breder (1927, p. 123), however, found A. ruberrimus more numerous than $B$. emperador in the Rio Chucunaque, a tributary of the Rio Tuyra in which we could not collect in 1912, when several other tributaries were sampled. Breder (1933) did not name this species in his list of fishes from Barro Colorado Island, and Dr. Behre (1928) did not obtain it in western Panama.

As this species occurs naturally on both slopes of central Panama, and as it was not taken in Miraflores Lake during the recent investigations no information was secured relative to its use of the locks as a passageway.

It occurs on both slopes of central Panama and in the Tuyra Basin. Costa Rica records probably are referable to $B$. terrabensis Meek (1914, p. 108).

\section{Bryconamericus zeteki sp. nov.}

Type from a creek in El Valle, Pacific slope, Panama. No. 106511 United States National Museum. Length $88 \mathrm{~mm}$. Also 59 paratypes, length 20 to $88 \mathrm{~mm}$.

Description of the type.-Head 4, depth 3.1, D. 11, A. 26, scales 36.

Body compressed, moderately deep; head short; snout shorter than eye, 3.9 in head; eye 3.2 ; interorbital 3.2 ; mouth small; lower jaw a little shorter than upper one; lower lip quite broad and thick, exceeding half the width of pupil; maxillary a little beyond anterior margin of pupil, forming an obtuse angle with premaxillary, notably longer than snout and nearly as long as eye; premaxillary with 2 series of teeth, the outer series with 10 teeth in an irregular row, alternating teeth being set farther forward, the inner series with 8 teeth set in an even row and notably larger than those of the outer series, all premaxillary teeth notched, having from 3 to 5 cusps; maxillary with 3 very small teeth anteriorly, having very low blunt cusps; lower jaw with 8 large teeth, having 3 to 5 cusps, followed on each side by abruptly smaller teeth; gill rakers small, about half length of pupil, 11 on lower limb of first arch; lateral line complete, moderately decurved, not wavy; scales moderately large, in regular series, 6 complete rows between lateral line and base of anterior 
rays of dorsal, and 5 between lateral line and base of ventral, 11 rows crossing back between dorsal and adipose, normal scales extending somewhat on base of caudal; dorsal fin rather high, with nearly straight margin, its origin equidistant from tip of snout and base of caudal; adipose very small, its base occupying only 1 row of scales, over beginning of posterior fourth of anal; caudal fin rather broadly forked, the lower lobe slightly longer than the upper one, scarcely as long as head; anal fin moderately long, with concave margin, its origin slightly posterior to base of last ray of dorsal, its base a little longer than head, 3.6 in standard length; ventrals small, extending slightly past vent, but failing to reach origin of anal, inserted rather less than an eye's diameter in advance of dorsal; pectorals failing to reach ventrals by 1 row of scales, 1.25 in head.

Color of preserved specimen brownish above, median line of back darker; lower parts pale silvery; humeral spot faint; a rather prominent lateral band, extending forward to upper anterior angle of gill opening, widest and most prominent posteriorly, ending in a caudal spot, which extends on base of caudal fin, and indefinitely to end of middle rays; body everywhere, except underneath, with dusky punctulations. Fins unmarked, except for dusky punctulations on the vertical ones, and on the outer rays of the pectorals. All enlarged teeth in both jaws with dark tips.

The variations noticed in the paratypes are as follows: Head 3.6 to 4 , depth 2.9 to 3.1, D. 10 or 11 , A. 25 to 27 , scales 6 (rarely 7 )35 to $38-5$, vertebrae $15+20$ or 21 ( 6 specimens dissected), snout 4 to 4.5 in head, eye 2.75 to 3.3 , interorbital 2.9 to 3.4 , caudal peduncle 2.1 to 2.5 , pectoral 1.15 to 1.25 .

No variation in the number and arrangement of the enlarged teeth in the premaxillaries and mandible has been noticed. However, the teeth on the maxillary vary from 2 to 3 , and have a roundish base, instead of an elongate one as in specimens of Astyanax described elsewhere. The second suborbital is uniformly wide and nearly or quite in contact with the lower limb of the preopercle, not leaving a naked triangular area between the suture of the first and second suborbitals as in Astyanax; from two-thirds to nearly as wide as eye at its broadest place. The pectorals in small specimens (under about $50 \mathrm{~mm}$. in length) reach a little farther back (to base of ventrals) than in larger ones, as usual in young fish. In the young the lateral band is narrower and more clearly defined, and the caudal spot extends definitely to the end of the caudal rays. All the enlarged 
teeth in the jaws have brownish tips, becoming darker to almost black in large examples.

The specimens from El Valle, here described, are close to $B$. $\mathrm{em}$ perador of central and eastern Panama, but they differ in having the scales in more regular series and in fewer longitudinal rows, in having thicker and broader lips, a slightly smaller eye, and rather shorter pectorals; and they also differ slightly in color.

In 22 specimens from El Valle only two individuals have 7 complete rows of scales between the lateral line and the base of the anterior rays of the dorsal, all the rest having 6 . Between the lateral line and the base of the ventral 5 complete rows are constantly present in the 22 specimens examined. In 15 specimens of $\mathrm{B} . \mathrm{em}$ -

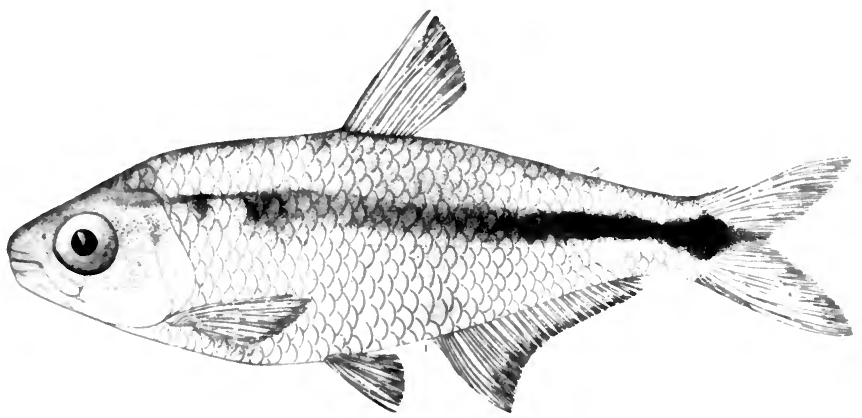

Fig. 4. Bryconamericus zctehi sp. nov. Type, $88 \mathrm{~mm}$. long. (From drawing by Andrew Pizzini.)

perador from the Canal Zone, in which the rows are more difficult to enumerate because of their unevenness, 7 rows were counted between the lateral line and the base of the anterior rays of the dorsal in nine specimens, and 8 rows in the other six. Six rows were counted in all these fish between the lateral line and the base of the ventral. No difference in the number of scales in the lateral series seems to exist.

The lower lip in the El Valle specimens is obviously thicker and broader, being fully half as wide as pupil, whereas in Canal Zone specimens (B. emperador) it is thinner and narrower, being scarcely half as wide as pupil. This difference might conceivably be due to a difference in preservation. However, the writer preserved all the specimens studied by the same method, the only difference being 
that the Canal Zone specimens have been in alcohol longer, having been collected two years earlier.

That the eye is slightly smaller in the El Valle specimens is evident only if specimens of equal size are compared. In a series of measurements, based on various sizes, the porportions overlap. However, in specimens ranging in length from about 70 to $90 \mathrm{~mm}$. the eye is contained in the head about 3.1 to 3.3 times in the El Valle material and 2.7 to 3 times in the Canal Zone specimens.

The pectoral fins fail to reach the base of the ventrals, except in the young, in the El Valle material as already shown, whereas in the Canal Zone specimens the pectorals reach to or beyond the base of the ventrals in all except very large specimens of $100 \mathrm{~mm}$. and upward in length.

In color the El Valle specimens differ in having the caudal spot extending more or less definitely to the end of the middle rays of caudal, whereas in Canal Zone specimens it projects only slightly on the base of the caudal rays. The tips of the teeth are not brown or black in B. emperador as in the El Valle specimens.

Northward three species of this genus, scleroparius, terrabensis and ricae, all from Costa Rica, are known. The first is known also from Nicaragua and the last extends slightly into western Panama. The El Valle specimens seem to differ in having a rather more slender body, rather shorter anal, more posteriorly placed dorsal, and more elongate caudal spot, which extends to the end of the middle caudal rays.

I have designated the El Valle specimens a distinct species, though their close relationship with $B$. emperador makes it questionable whether they should be considered distinct, or only a subspecies of emperador.

I take pleasure in naming this fish for Professor James Zetek, the well-known naturalist of the Canal Zone and Panama.

Bryconamericus cascajalensis Meek and Hildebrand.

Bryconamericus cascajalensis Meek and Hildebrand, Field Mus. Nat. Hist., Zool. Ser., 10, p. 284, pl. 19, 1916-Rio Cascajal, Porto Bello, Panama.

Known only from the type material from Porto Bello.

Bryconamericus ricae Eigenmann.

Bryconamericus peruanus ricae Eigenmann, Bull. Mus. Comp. Zool., 52, p. 106, 1908-Rio Chitaria, tributary of Rio Reventazon, Atlantic slope, Costa Rica.

This form is included in the fauna of Panama on the basis of a record by Behre (1928, p. 320), who listed it from the Atlantic slope 
of extreme western Panama, province of Bocas del Toro, under the name B. peruanus ricae. However, Eigenmann (1927, p. 393) raised ricae to full specific rank. It differs from the other Panama species herein recognized in the more anterior position of the dorsal fin, the origin of which is described as being an eye's diameter nearer to snout than base of caudal. It seems probable from published accounts that ricae may have somewhat more numerous scales and anal fin rays than the other Panama forms, the numbers given being, scales $7-39$ to 406 , anal 28 to 31 . A comparison of specimens, which has not been possible, probably would reveal other differences.

Known from the Atlantic slope of Costa Rica, and somewhat across the border in Panama.

Hemibrycon dariensis Meek and Hildebrand.

Hemibrycon dariensis Meek and Hildebrand, Field Mus. Nat. Hist., Zool. Ser., 10, p. 285, pl. 20, 1916.

Originally described from specimens taken in several different places in the Rio Tuyra and its upper tributaries. Breder (1927, p. 123) recorded dariensis from several localities on the Rio Chucunaque and its tributaries. To date it is known only from the Tuyra Basin.

\section{Hyphessobrycon Durbin.}

A single species of this genus is known from Panama. The genus is characterized by the short compressed body with elevated back, by the presence of two series of premaxillary teeth, by the incomplete lateral line, and by the naked and unmodified caudal fin in both sexes.

\section{Hyphessobrycon panamensis Durbin.}

Hyphessobrycon panamensis Durbin, in Eigenmann, Bull. Mus. Comp. Zool., 52, p. 101, 1908 - Rio Boquerón, Panama; Meek and Hildebrand, Field Mus. Nat. Hist., Zool. Ser., 10, p. 287, 1916.

Taken only in the Chagres Basin in 1911 and 1912. In 1935 I secured specimens in Gatun Lake near Gatun, and in a small stream flowing into Gatun Lake crossing Madden Dam Road. Behre (1928, p. 318) reported it from some small streams of the Atlantic drainage of extreme western Panama, where it seems to be common.

It is a small species, apparently rarely exceeding a length of 50 $\mathrm{mm}$. It is most readily distinguished from the other small characins of the vicinity by the incomplete lateral line, which is present on only about 8 to 13 scales, and by the rather plain color. This species has no caudal spot, though it does have a narrow dark lateral band, at least on the posterior half of the body. It also has a vertically 
elongate dusky shoulder spot, usually followed by a second less distinct spot. Furthermore, it has an ill-defined dark band on the median line of the back. The fins are unmarked, except for dusky punctulations.

The following counts and measurements are based on 6 specimens (unless otherwise stated), ranging in length from 30 to $47 \mathrm{~mm}$.:

Head 3.5 to 3.6 , depth 2.5 to 2.8 , D. 10 or 11 , A. 24 or 25, P. 11 or 12 , scales 6 or $7-30$ to $33-5$ or 6 , vertebrae $13+18$ (one specimen counted). Distance from snout to dorsal 1.6 to 1.8 in standard length, base of anal 3.2 to 3.4 , pectoral 4 to 4.5 . Snout 4.5 to 5.5 in head, eye 2.5 to 2.8 , interorbital 3.4 to 3.9. Premaxillaries with 2 series of teeth; the outer series with 3 teeth on each side; inner series with 4 larger teeth on each side; maxillary with 2 or 3 very small teeth anteriorly; mandible with 1 series of teeth, with 4 enlarged ones anteriorly on each side, followed by smaller ones; all teeth with 3 to 5 cusps.

The range apparently extends along the Atlantic slope from the Panama-Costa Rica border to the Magdalena Basin in Colombia.

\section{Thoracocharax Fowler.}

The species of this genus are characterized by the short, deep, compressed body with a greatly dilated thoracic region, which, together with the abdomen, forms a semicircular disk with a sharply compressed edge. An adipose fin is present, the pectoral fins are large, and the anal long (with 33 to 36 rays in Panama species).

The genus is widely distributed, ranging from Panama southward to Paraguay. The species are rather extensively used as "pet fish" in home aquaria. The peculiarly expanded thoracic region with sharp edge has suggested the name "hatchet fish," which is used by aquarists. The large pectorals and the ability to "skip" some distance over the water has called forth the name "fresh-water flying fish," which also is used by aquarists. Because of the "flying" propensities it is necessary to cover (screen) the aquaria in which these fishes are kept.

\section{Thoracocharax maculatus (Steindachner).}

Gasteropelecus maculatus Steindachner, Denkschr, Akad. Wiss. Wien, 41, p. 168, 1879 - Rio Mamoni, Chepo, Panama.

Thoracocharax maculatus Meek and Hildebrand, Field Mus. Nat. Hist., Zool. Ser., 10, p. 288, 1916.

Taken during the recent investigation, only in swamps at the La Jagua Hunting Club, about 15 miles east of Panama City, where 
it was numerous. In 1911 and 1912 we took it in the Chorrera, Bayano and Tuyra basins, but not on the Canal Zone. All the specimens were collected by us either in sluggish or standing water, and mostly in stagnant swamps. However, Breder (1928, p. 125) stated, concerning his collections in the Chucunaque Basin: "Taken commonly only above the head of tide, in some places abundant, especially in fast small side streams."

A collector of "petfish" informed me that this fish could be caught only at night. However, the numerous specimens taken at various places in Panama by us were all seined by day. It is true, nevertheless, that many fish escaped either by skipping and swimming away from the net, or by "flying" over the cork line. Mr. Breder (1928, p. 125) reported some observations concerning "flight." He said that at night, when the fish appear to be most active, they sometimes were seen "to leap in a shoal and travel five feet or more before cutting into the water again. At such times they often rise to a height of six inches or more from the water's surface." Mr. Breder has suggested that it seems probable that the large thoracic muscles may make it possible for the fish to use the enlarged pectoral fins to a limited extent as wings.

Among the many collected at the La Jagua Hunting Club, one specimen, $53 \mathrm{~mm}$. long, which is otherwise normal, is entirely without an adipose fin, the usual place of insertion being scaled over with normal scales.

This species has been taken on the Pacific slope only in Panama, from the Rio Chorrera eastward, but not in the Canal Zone. It ranges into Colombia where it is known from the Rio San Juan on the Pacific side, and the Rio Atrato on the Atlantic.

Creagrutus notropoides Meek and Hildebrand.

Creagrutus notropoides Meek and Hildebrand, Field Mus. Nat. Hist., Zool. Ser., 10, p. 68, 1912-Rio Indio, upper tributary of Rio Chagres; p. 289, pl. $21,1916$.

Known only from the upper Chagres Basin.

\section{Creagrutus affinis Steindachner.}

Creagrutus affinis Steindachner, Denkschr. Akad. Wiss. Wien, 42, p. 27, 1880 - Cauca, near Cáceres.

Creagrutus simus Meek and Hildebrand, Field Mus. Nat. Hist., Zool. Ser., 10, p. 85, 1913-Rio Cupe, tributary of Rio Tuyra; p. 290, 1916.

This species appears under the name $C$. simus in our earlier general work, as shown above. However, that name was placed in synonymy by Eigenmann (1922, p. 146), though there seemed to 
be a small difference in the number of longitudinal rows of scales between Rio Tuyra specimens (simus) and Atrato ones (affinis).

Mr. Breder (1927, p. 124) recorded 145 specimens, ranging in length from 18 to $58 \mathrm{~mm}$., from several places in the Chucunaque Basin. This fish has been found also in the Tuyra, Atrato, San Juan, and Cauca basins.

\section{Roeboides Günther.}

The local species of this genus are readily recognized by the strongly compressed elongate body, which is often almost transparent. In adults the outline is deeply concave over the head. External tooth-like processes project forward from the upper jaw. The anal fin is very long (with 42 to 50 rays in Panama species), the adipose fin is well developed, and a large spine is situated on the shoulder girdle in front of the base of the pectoral. The local species reach a length of 150 to $170 \mathrm{~mm}$.

As the two local species of this genus of the opposite slopes of the Canal Zone are well differentiated in color, these fishes apparently would be favorable ones to show cross-breeding if it had taken place in the Canal. However, as stated subsequently, no evidence was found indicating that intermingling or crossing over has taken place.

\section{Roeboides guatemalensis (Günther).}

Anacyrtus (Roeboides) guatemalensis Günther, Cat. Fish. Brit. Mus., 5, p. 347, 1864-Rio Chagres, etc.

Roeboides guatemalensis Meek and Hildebrand, Field Mus. Nat. Hist., Zool. Ser., 10, p. 291, 1916.

Numerous specimens were taken in Gatun Lake. The species was secured in 1935 and 1937, also, in an abandoned reservoir at Mount Hope, and in a creek tributary to Gatun Lake on Madden Dam Road. It is very common on the Atlantic slope of Panama, as stated by us (1916, p. 292), and its range extends northward into southern Mexico. Behre (1928, p. 318) recorded it from the Rio Chiriquí del Tire near Caldera, Pacific slope, with the remark: "These fishes (24 specimens) have hitherto been described from the Caribbean coast. We found them only on the Pacific slope."

The specific differences between this species and its relative, occidentalis, are shown in a key by Meek and Hildebrand (1916, p. 291). The most readily available recognition mark is the difference in color. $R$. occidentalis has a large black spot on the side about an eye's diameter behind a rather obscure shoulder spot present in both species. The second black spot is missing in guatemalensis. How- 
ever, this species generally has a black streak, variable in length, within the silvery lateral band, which occidentalis does not have.

The many specimens at hand from Gatun Lake, taken chiefly at Barro Colorado Island and in the upper end of the lake toward Madden Dam, have been carefully compared with an equally large number of specimens of the genus from the Rio Cocoli and Miraflores Lake. Absolutely no indication of interming.ing or cross-breeding was found, as the Gatun Lake specimens are typical guatemalensis and those from Miraflores Lake and the Rio Cocoli are typical occidentalis. Therefore, no evidence that these species have passed through the Pedro Miguel Locks was obtained.

The range of this species has been given as extending from southern Mexico to the Rio Chagres in Panama. Behre (1928, p. 318) reported it from the Pacific slope of western Panama, but did not get it on the Atlantic side. Meek (1914, p. 109) reported it from both slopes of Costa Rica. However, specimens from Liberia, Pacific slope of Costa Rica, studied by me $(1930, \mathrm{p} .2)$ were $R$. salvadoris, a species readily separable from $R$. guatemalensis by the color, as it has no black in the silvery lateral band, but has a black spot on the side anteriorly, like $R$. occidentalis, except that the spot is much smaller. Evidently further study, and comparisons of specimens, are necessary to determine the exact distribution.

\section{Roeboides occidentalis Meek and Hildebrand.}

Roeboides occidentalis Meek and Hildebrand, Field Mus. Nat. Hist., Zool. Ser., 10, p. 293, pl. 23, 1916.

In addition to numerous individuals taken in the Rio Cocoli and Miraflores Lake in 1935 and 1937, one specimen, $85 \mathrm{~mm}$. long, was taken in the upper chamber of Miraflores Locks (west side). Numerous specimens, also, were seined in swamps at the La Jagua Hunting Club, and a few in the Rio Pacorá.

The differences in color between this species and its common Atlantic congener are pointed out in the discussion under guatemalensis. Although minor structural differences exist, the differences in color constitute the most easily used field characters for distinguishing the species. In the illustration (retouched photograph) offered by Meek and Hildebrand (1916, pl. 23) the prominent black lateral spot is shown as half above and half below the lateral line. This position must be regarded as unusual, at least, as in the large series of specimens now at hand it at most extends slightly below the lateral line, but is more usually wholly above it. 
No indication of intermingling of this species and guatemalensis through Pedro Miguel Locks is evident. Indeed, neither species was obtained in these locks when they were dewatered in 1937, though one specimen of occidentalis was found in the upper chamber of Miraflores Locks. No evidence was secured indicating that the species has passed through these lower locks to brackish and salt water, which it normally does not inhabit.

Breder (1927, p. 126) reported this species as "Not common, but taken in all the larger streams except the Rio Chico and Tupisa" in the Chucunaque Basin. It is known only from the Pacific slope of central and eastern Panama. On the Pacific slope of Colombia, and probably Ecuador, according to Eigenmann (1922, p. 162), it is replaced by $R$. hildebrandi; and if Dr. Behre's identification (1928, p. 318 ) is correct it is replaced by $R$. guatemalensis (of the Atlantic slope) on the Pacific side in western Panama.

Brycon Müller and Troschel. SÁBALO PIPON.

The common name of all the species of this genus among the natives of Panama seems to be "sábalo pipon," meaning an obese herring. These fishes reach a moderately large size, examples upward of 2 feet $(60 \mathrm{~cm}$.) in length, at least of $B$. chagrensis, having been seen. They are valued as food, though quite bony. Although their teeth are relatively large and numerous, suggesting an animal diet, the alimentary canal is rather long, as in herbivorous fishes. Stomach contents show that the diet is a mixed one, consisting of both animal and plant remains. It is noteworthy that these fishes may be caught either with meat bait or with banana and perhaps other vegetable baits.

The collections made by Dr. Behre in western Panama in 1923, and the recent ones (1935 and 1937) by the writer in central Panama and westward to El Valle, contain three species of Brycon not included in our earlier work (1916), two of which apparently are new. A new key including the species added to the fauna of Panama is introduced.

The close relationship of the new species described from the Pacific slope (see p. 222), west of the Canal Zone, with species occurring in the Chagres Basin suggests a recent "crossing over" from the Atlantic to the Pacific slope. Both striatulus and argenteus of the Pacific watershed of central Panama are apparently replaced on the Pacific slope of western Panama by near relatives of chagrensis and petrosus of the Chagres Basin. 


\section{KEY TO SPECIES OF BRYCON}

a. Scales small, 64 to 83 between upper angle of gill opening and base of caudal; anal fin much longer than head, with 30 to 37 rays.

b. Mandibular teeth very large and strong, usually 8 (rarely 7 or 9 ) in outer series; maxillary teeth very small and few, only 9 or 10 present; premaxillary teeth small, 12 to 14 in outer series; scales moderately large, 64 to 73 , usually fewer than 70,18 to 21 rows crossing back between dorsal and adipose $\ldots \ldots \ldots \ldots \ldots \ldots \ldots \ldots \ldots \ldots \ldots \ldots \ldots \ldots \ldots$ striatulus.

bb. Mandibular teeth rather smaller and more numerous, usually more than 10 in outer series; premaxillary teeth larger and more numerous, 15 or more in outer series.

c. Pectoral long, frequently reaching nearly or entirely to base of ventral, seldom falling short of this point by more than 2 rows of scales, 4.1 to 5 in standard length; scales rather small and in more or less irregular series, 68 to 83 (usually more than 70 ) between upper angle of gill opening and base of caudal; teeth rather small, 14 to 20 in outer series on mandible, 10 to 13 on maxillary, and 15 to 18 in outer series on premaxillaries; second suborbital narrow, with rounded lower anterior

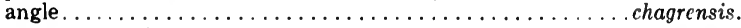

$c c$. Pectoral shorter, generally failing to reach base of ventral by 3 to 6 scales, 5.2 to 5.8 in standard length; scales somewhat larger and in more regular series, 66 to 79 between upper angle of gill opening and base of caudal; teeth somewhat larger, 10 to 14 (rarely 16) in outer series on mandible, 12 to 15 on maxillary, and 17 to 20 in outer series on premaxillaries; second suborbital broad, its lower anterior angle less rounded........................... nehreae sp. nov.

aa. Scales larger, 43 to 58 between upper angle of gill opening and base of caudal; anal fin little if any longer than head, except in guatemalensis.

d. Anal fin notably longer than head, with 32 to 38 rays; scales moderately small, 50 to 56 between upper angle of gill opening and base of caudal, 10 rows between lateral line and origin of dorsal, 4 or 5 between lateral line and base of ventral. . . . . . . . . . . . . . . . . . . . . .

dd. Anal fin about equal to length of head, with 24 to 28 rays.

$e$. Scales moderately small, 48 to 58 between upper angle of gill opening and base of caudal, 7 to 10 rows between lateral line and origin of dorsal, 3 or 4 between lateral line and base of ventral, and 15 to 18 series crossing back between dorsal and adipose.

f. Pectoral long, reaching nearly or fully to base of ventral in small specimens, proportionately shorter in adult, about 1.2 in head; snout strongly projecting, 2 rows of teeth exposed in advance of lower jaw; teeth rather large, 8 to 10 enlarged ones in outer series on mandible, 12 to 14 in outer series on premaxillaries; scales rather small, 53 to 58 between upper angle of gill opening and base of caudal; sides with more or less definite dark cross bars or reticulations formed by black margins on the scales................. petrosus.

ff. Pectoral rather shorter, failing to reach ventral in small specimens by 2 or 3 rows of scales, about 1.4 in head; snout projecting less strongly, leaving only one row of premaxillary teeth exposed in advance of lower jaw; teeth smaller, though apparently equal in number; scales somewhat larger, about 48 to 55 ; sides plain

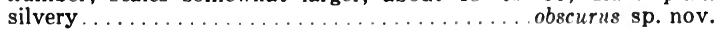

$e e$. Scales larger, 43 to 48 between upper angle of gill opening and base of caudal, 7 or 8 rows between lateral line and origin of dorsal, 3 between lateral line and base of ventral, and 11 to 14 series crossing back between dorsal and adipose; snout projecting very little, with lower jaw reaching outer row of premaxillary teeth.......... argenteus. 


\section{Brycon striatulus (Kner).}

Chalcinopsis striatulus Kner, Sitzber. Bayer. Akad. Wiss., München, p. 226, 1863-Panama.

Brycon striatulus Meek and Hildebrand, Field Mus. Nat. Hist., Zool. Ser., 10, p. 294, 1916.

No specimens of this species were secured during the recent investigations. A discussion of its relationship with chagrensis is included in the account of that species.

Since the publication of our earlier work, Breder (1927, p. 119) recorded this fish from several localities in the Chucunaque Basin, and Behre (1928, p. 317) listed B. striatulus from an upper tributary of the Rio Chiriquí on the Pacific slope of far western Panama. However, the specimens so listed by Dr. Behre are apparently representatives of a new species herein named $B$. behreae.

The species has been taken only from streams on the Pacific slope of central and eastern Panama, from the Rio Chorrera to the Rio Tuyra.

\section{Brycon chagrensis (Kner).}

Chalcinopsis chagrensis Kner, Sitzber. Bayer. Akad. Wiss. München, p. 223, 1863-Rio Chagres.

Brycon chagrensis Meek and Hildebrand, Field Mus. Nat. Hist., Zool. Ser., 10, p. 295, 1916.

Many specimens were taken in the upper part of Gatun Lake, that is, between Gamboa and Madden Dam. Additional specimens were taken in Miraflores Lake and the Rio Cocoli, tributary to Miraflores Lake, and one in Pedro Miguel Locks.

$B$. chagrensis is an Atlantic slope species, heretofore definitely recorded only from the Rio Chagres Basin. To reach Miraflores Lake and the Rio Cocoli the fish had to pass through Culebra Cut and Pedro Miguel Locks.

The closest Pacific slope congener, B. striatulus, which is known from the Tuyra, Bayano, Juan Diaz, and Chorrera rivers, was not taken in the Rio Grande system (the main stream having been destroyed during the construction of the Panama Canal) in 1911 and 1912, before the opening of the Canal, when rather thorough collecting was carried out in its then largely undisturbed tributaries. Nor was it ever recorded from this river basin. As it does not appear in the recent collections, and as the specimens of chagrensis (and petrosus) seem quite typical, showing no signs of cross-breeding, it may perhaps be assumed that striatulus does not occur in the Rio Grande Basin. 
$B$. chagrensis has been synonymized with $B$. striatulus (Kner) by various authors (Regan, 1908, p. 169: Behre, 1928, p. 317; Jordan, Evermann and Clark, 1928 [1930], p. 98). This treatment has led to a careful recheck of the species of Brycon from the opposite slopes of Panama.

There can be no reasonable doubt about the specific distinctness of the specimens from the Atlantic and Pacific drainages of eastern Panama. The differences were mostly correctly indicated long ago by Kner and Steindachner (Abhandl. Bayer. Akad. Wiss. München, 10,1866 , pp. 38 to 43 , pl. 5, figs. 2 and 3 ), who made the mistake, however, of stating that striatulus has 8 to 10 mandibular teeth in the outer series "an jederseits" and chagrensis 14. "On each side" is clearly a mistake, for the species do not have as many teeth as twice the number given, as shown by the excellent illustrations offered. The number given is plainly the total number of enlarged mandibular teeth, which are followed on each side by about 2 or 3 smaller ones.

The differences between $B$. striatulus and chagrensis were stated in greater detail by Meek and Hildebrand (1916, pp. 293 to 299), who pointed out a difference also in the size and number of maxillary teeth, those of striatulus being small, and only 9 or 10 in number, whereas those of chagrensis are larger and more numerous, each maxillary being provided with 12 or 13 teeth. These data have been rechecked with specimens and found to be correct. It may be added that a similar difference in size and number in the outer series of premaxillary teeth exists, striatulus having 12 to 14 rather small teeth and chagrensis 16 to 18 somewhat larger ones.

Kner and Steindachner pointed out that striatulus has larger scales than chagrensis. This difference is only an average, instead of an absolute one, as already shown by Meek and Hildebrand. The overlapping is due in part to a rather large variation in the actual number of series of scales present, and also in part no doubt to errors and to differences in place of enumeration. The scales are small and the series not always very regular, making them difficult to count accurately, especially in small specimens. The writer has enumerated the lateral series of scales of one specimen several times and obtained results that differed by as much as 5 scales. Furthermore, it makes a difference whether the series is counted along the upper part of the side from the upper anterior angle of the gill opening to the base of the caudal, or lower down, along the lateral line between the margin of the opercle and the base of the caudal where the scales 
are larger. If the series is taken along the upper part of the side, between the upper angle of gill opening and the base of the caudal, the range for striatulus may stand as 64 to 73 , and for chagrensis as 70 to 83 . Generally striatulus has fewer than 70 and chagrensis more than 70 oblique series of scales on that part of the side.

There is so little difference in the color patterns of the two species that they cannot be separated on that basis, although large specimens of striatulus often lack the blackish crossbars or reticulations which are always retained in life by chagrensis, so far as can be determined from the material at hand.

This species remains known only from the Chagres Basin.

\section{Brycon behreae sp. nov.}

Brycon striatulus Behre (not Kner), Ann. Carnegie Mus., 18, p. 317, 1928.

Type from Rio Chiriquí del Tire, above Caldera, Pacific slope, western Panama. No. 5582 California Academy of Sciences. Total length $330 \mathrm{~mm}$., standard length $265 \mathrm{~mm}$.

Description of the type.-Head 4.75; depth about 3.2 ; D. 11 ; A. 32, including undivided rays; scales 68 .

Body rather robust; caudal peduncle slender, its depth 2.5 in head; head short, deep; snout rather short, conical, 3.2 in head; eye 4.5; second suborbital broad, leaving little of the cheek exposed, its lower anterior angle nearly a right angle, its depth at vertical of posterior margin of pupil 5 in head; mouth moderate, maxillary reaching opposite middle of eye; lower jaw shorter than upper, leaving 2 rows of teeth exposed in advance of it; teeth large, the premaxillary ones laterally in 2 series, anteriorly more or less definitely in 4 series, the outer series with a total of 17 teeth, each maxillary with 15 teeth, mandible with a total of 15 teeth; gill rakers slender, scarcely as long as pupil, 16 on lower limb of first arch; lateral line complete, decurved anteriorly; scales firm, with very prominent striae, in regular series on sides, 24 rows crossing back before dorsal, 19 between dorsal and adipose, 14 rows between lateral line and origin of dorsal, and 7 rows between lateral line and base of ventral; dorsal with straight margin, its origin equidistant from snout and base of caudal; caudal broadly forked, the lower lobe about an eye's diameter longer than the upper one; anal fin elevated anteriorly, the last 12 or 13 rays of about equal length, its origin a little posterior to vertical from end of base of dorsal; ventrals failing to reach vent by 5 rows of scales; pectorals short, failing to reach ventrals by 6 rows of scales, 5.7 in standard length. 


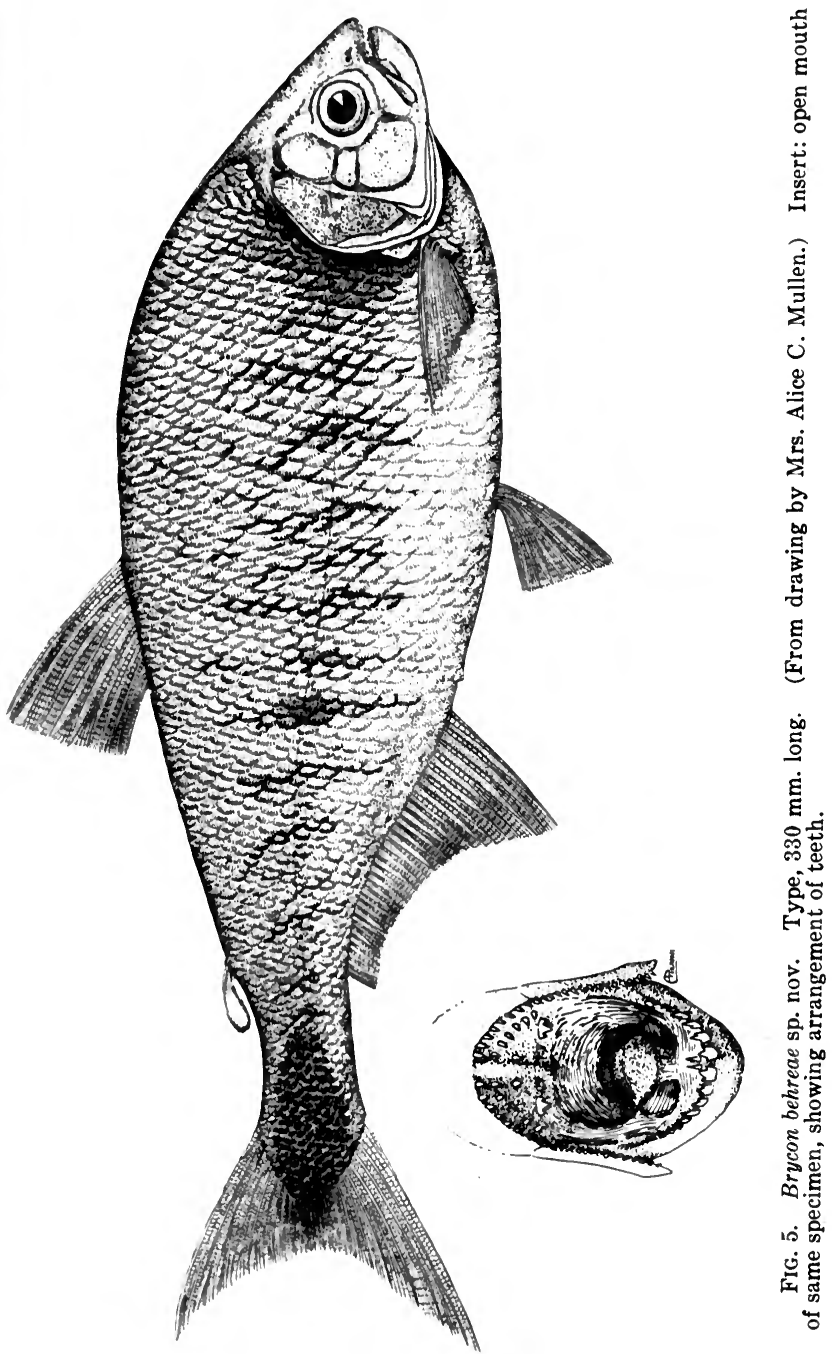


Color bluish silvery above, pale below; a black vertical band under and behind opercular margin, middle of sides with rather prominent black bars; a black blotch at base of caudal; ventrals pale; all the other fins more or less dusky, at least on membranes.

This species is based on specimens collected in the Rio Chiriquí del Tire and tributaries, Rio Chiriquí Basin, Pacific slope of western Panama, in the general vicinity of Caldera, by Dr. Ellinor H. Behre, for whom I am pleased to name the species. This material is now mostly in the museum of the California Academy of Sciences and the Carnegie Museum. Through the kindness of $\mathrm{H}$. Walton Clark of the first mentioned institution, and Arthur W. Henn of the latter, I have been able to compare 31 specimens of Dr. Behre's collection with many specimens from central and eastern Panama.

The specimens from the Pacific slope of western Panama (behreae) were identified as $B$ :ycon striatulus by Dr. Behre, who regarded $B$. chagrensis as a synonym of striatulus. However, well-marked characters distinguish the two, as shown in our earlier work (1916), and restated with some additions in this paper in the account of B. chagrensis. B. striatulus is not represented among Dr. Behre's specimens from the Pacific slope of western Panama examined by me. The specimens are so closely related to chagrensis, however, that they seem scarcely specifically distinct. Some differences have been noticed, as shown subsequently.

It is very interesting to find striatulus apparently replaced by a very close relative of chagrensis on the Pacific slope of western Panama. It is of interest, furthermore, that Dr. Behre (1928, p. 318) did not find chagrensis in the streams of the Atlantic slope of western Panama, but reported instead $B$. guatemalensis. To date, then, $B$. chagrensis remains known only from the Chagres Basin.

The specimens from the Pacific slope of western Panama (behreae) vary more prominently among themselves than Chagres River specimens (chagrensis). Because of the great variations some of the specimens differ rather strikingly from those of the Chagres, but others are distinguished with difficulty, and still others are intermediate. The most constant character in which the specimens from western Panama differ is the shorter pectoral fin, as shown by the proportional measurements given subsequently. The average number of scales in a lateral series also is a little lower; the teeth, though usually agreeing in number are larger; often the snout projects less prominently, though that is a very variable character among specimens from western Panama, as in some specimens only a 
single row of premaxillary teeth is exposed whereas in others as many as three rows are in advance of the lower jaw; the body in the larger specimens seems to be rather more robust, but accurate measurements cannot be made as the specimens have been eviscerated, the smaller specimens are quite as slender as those from the Chagres River; and the second suborbital is generally broader with a sharper lower anterior angle, leaving less of the cheek exposed. The color of preserved specimens is nearly identical, the dark bars on the sides of large specimens being a little more prominent on the western Panama material.

The following counts and proportions are based on 21 specimens collected in the Rio Chiriquí Basin, western Panama, and on 22 specimens from the Rio Chagres Basin. Counts and proportions of the latter are placed in parentheses: Head 3.5 to 4.7 (4 to 4.8); depth 3 to 3.7 (3.2 to 3.5$)$; D. 10 or 11 (11); A. 32 to 35 (30 to 36 ); scales 66 to 79 , average 71 ( 68 to 83 , average 74.5 ); rows of scales crossing back in front of dorsal fin 20 to 27 , average 24.4 (25 to 30, average 26.4 ); rows of scales crossing back between dorsal and adipose 16 to 22 , average 20 ( 18 to 25 , average 21.1 ). Snout 3.4 to 4.1 (3.5 to 3.8 ) in head; eye 3.2 to 3.8 (3.4 to 4.1 ); pectoral 1.2 to 1.35 (1 to 1.2 ) in head, or 5.2 to 5.8 (4.1 to 5 ) in standard length. Teeth in outer row on premaxillary 17 to 20 (15 to 18); teeth on maxillary 12 to 15 (10 to 13 ); teeth in outer series on mandible 10 to 16 , average 13 (14 to 20 , average 16.7).

\section{Brycon guatemalensis Regan.}

Brycon guatemalensis Regan, Biol. Cent. Amer., Pisces, p. 168, 1907-Guatemala, Atlantic drainage; Behre, Ann. Carnegie Mus., 18, p. 318, 1928.

This species is included in the list of Panama fishes on the basis of a record by Behre $(1928$, p. 318$)$, who recorded it from the Rio Guarumo and the Rio Cricamola, both emptying into the Chiriquí Lagoon, Atlantic slope of western Panama.

I have not seen Dr. Behre's specimens, but have examined 8 specimens of guatemalensis in the National Museum, from Guatemala and Nicaragua. The species is readily recognized by the long anal fin, which is longer than the head and has 32 to 38 rays (including simple rays), and by a moderate number of scales, there being 50 to 56 oblique series along middle of side between the upper angle of gill opening and base of caudal, 9 or 10 longitudinal rows between the lateral line and origin of dorsal, and 4 or 5 rows between the lateral line and base of ventral. This combination of anal fin ray and scale counts is found in no other species of the genus known from Panama. 
The teeth are rather small and numerous; premaxillaries with 16 or 17 in the outer series, maxillary with 16 or 17 , and mandible with 10 large ones, followed on each side by 2 or 3 smaller ones, in the outer row. The relationship of this species to argenteus, a rather near relative, is discussed in the account of the last-named species.

As here understood, this species ranges on the Atlantic slope from Guatemala to Western Panama.

Brycon petrosus Meek and Hildebrand.

Brycon petrosus Meek and Hildebrand, Field Mus. Nat. Hist., Zool. Ser., 10, p. 184, 1913-upper Chagres; and p. 297, pl. 24, 1916.

Small specimens were taken in the Rio Boquerón, in current at the edge of Madden Lake; in a rocky creek, tributary to Gatun Lake, near Madden Dam; and in the Rio Cocoli. B. petrosus was previously recorded only from the Chagres Basin. It no doubt reached the Rio Cocoli by passing from Gatun Lake through Culebra Cut, the Pedro Miguel Locks, and Miraflores Lake.

A close relative is its Pacific slope congener, B. argenteus. Though that species is recorded from streams both east and west of the Panama Canal, namely, from the Tuyra, Bayano and Chorrera rivers, it has not been found in the Rio Grande drainage. Since fairly thorough collecting has been done it may be assumed that the species does not occur in such parts of this river system as remain, because the main stream was destroyed in the construction of the Canal.

$B$. argenteus differs from petrosus chiefly in having larger scales. The first named has from 43 to 48 oblique series of scales on the side between the upper angle of the gill opening and the base of the caudal; 7 or 8 longitudinal rows between the lateral line and origin of dorsal; 3 between the lateral line and base of ventral; and 11 to 14 series crossing the back between the dorsal and adipose. B. petrosus, on the other hand, has 53 to 58 scales along the side, counted in the same way; 9 or 10 rows between the lateral line and origin of dorsal; 3 or 4 between the lateral line and base of ventral; and 15 to 18 series between dorsal and adipose.

Brycon argenteus and petrosus both differ from striatulus and chagrensis in having larger scales, the combined range being 43 to 58 in lateral series in the first two and 64 to 80 in the last two. Also, the anal fin is shorter in argenteus and petrosus which have a combined range of 24 to 28 rays, including the simple ones, whereas striatulus and chagrensis have 30 to 37 rays. 
The close relationship of this species to $B$. obscurus sp. nov. is pointed out in the discussion of that species.

Brycon obscurus sp. nov.

Type from a creek in El Valle, Pacific slope, Panama. No. 106512 United States National Museum. Total length $96 \mathrm{~mm}$.. standard length $77 \mathrm{~mm}$.

Head 3.7 ; depth 3.5 ; D. 10 ; A. 28 , including undivided rays; scales 55. Body elongate, compressed; dorsal profile rather more strongly curved than the ventral; snout moderately pointed, 3.8 in head; eye 3.5 ; interorbital 3.35 ; lower jaw moderately long with a broad lip about three-fourths diameter of pupil, covering second series of premaxillary teeth; maxillary not quite reaching middle

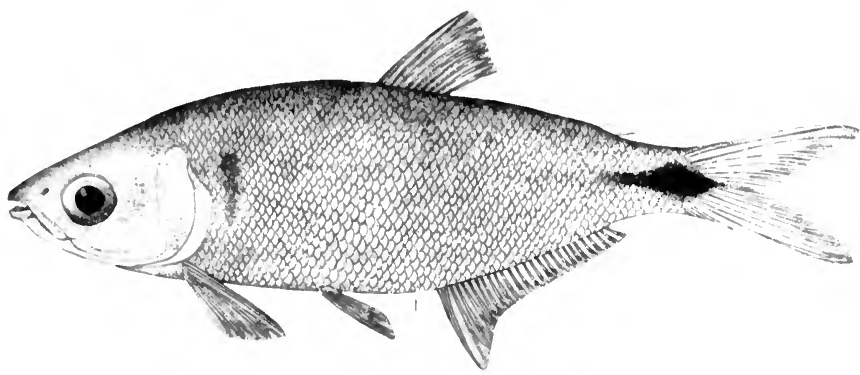

Fig. 6. Brycon obscurus sp. nov. Type, $96 \mathrm{~mm}$. long. (From drawing by Andrew Pizzini.)

of eye, 2.3 in head; premaxillary teeth anteriorly in 3, and laterally in 2 series, a total of 14 small tricuspids in the outer series; about 12 very small ones on maxillary; teeth in lower jaw large, anteriorly 8 large ones with 3 to 5 cusps, followed on each side by 1 or 2 smaller teeth (teeth on right side of lower jaw abnormal, apparently having been broken, being without cusps); gill rakers scarcely more than half the diameter of pupil, 14 on lower limb of first arch; lateral line strongly decurved; scales moderately small, 10 rows between lateral line and base of dorsal, 4 between lateral line and base of ventral, 15 rows crossing back between dorsal and adipose; dorsal with very slightly concave margin, the longest anterior rays reaching somewhat beyond the posterior ones if deflexed, its origin about midway between base of ventrals and origin of anal, equidistant from anterior 
margin of eye and base of caudal; caudal deeply forked; anal fin moderately long, its base equal to head, the origin just behind base of dorsal; ventral fins reaching vent; pectorals failing to reach ventrals by 2 or 3 rows of scales, 1.4 in head.

Color mostly plain silvery; back bluish; a short dark vertical bar at shoulder; no other dark cross-markings; a dusky blotch on opercle; base of caudal with a prominent elongate black spot. No lateral band; posterior half of body with a horizontal line along middle of side. Fins unmarked, except for dusky chromatophores.

In addition to the type, 5 paratypes, ranging in length from 42 to $52 \mathrm{~mm}$., are at hand. These small specimens are more slender than the larger one, as usual in this genus, the depth being contained 3.6 to 3.8 times in the standard length. The scales are rather difficult to count. However, the range seems to be 48 to 54 , with 10 or 11 complete rows between the lateral line and base of dorsal, and 4 between the lateral line and base of ventral. Eight enlarged teeth in the lower jaw are constantly present. The range in the number of anal rays is 25 to 28 , including the simple ones. The small specimens are less silvery than the type, and have an obscure dusky lateral band. In other respects they are similar to the type in color.

This species is close to petrosus, a species indigenous to the upland streams in the Rio Chagres Basin. More and larger specimens are required to determine the exact relationship. However, the El Valle specimens appear to be more slender. This difference is evident only if specimens about equal in size are compared, as the species of this genus tend to become deeper with age. The eye, also, has the appearance of being smaller, and the snout projects less strongly beyond the lower jaw, the second series of premaxillary teeth being well in advance of lower lip in petrosus, whereas in the present species the lower lip almost if not quite covers the second series. The lower lip in the El Valle specimens seems to be broader and thicker, being fully three-fourths the width of pupil, whereas in petrosus it is scarcely half as wide as pupil. The teeth, especially the maxillary and premaxillary ones, are rather smaller in the El Valle specimens, though the average number may be equal. The pectoral and ventral fins have the appearance of being rather shorter, failing by 2 or 3 rows of scales to reach, respectively, the base of the ventrals and the origin of the anal, whereas in young petrosus these fins usually reach the points named. Finally, the species differ in color. The El Valle specimens are plain silvery on sides, none of the scales having dark 
margins, whereas in young petrosus many scales have dark margins, tending to form blackish reticulations or crossbars.

If more and larger specimens come to hand, other and more distinctive characters may become evident. Though the relationship with petrosus of the Chagres River (Atlantic drainage) is close, it seems improbable that the El Valle specimens (Pacific drainage) will prove to be identical. It is interesting, however, that the relationship of petrosus is nearer to the El Valle specimens than to argenteus, occurring in the Chorrera and Bayano rivers, immediately opposite the Chagres. To date no identical specimens from the opposite slopes of eastern Panama have been found among many specimens examined by the writer. Recently (1935 and 1937) the writer took both $B$. chagrensis and $B$. petrosus in the Rio Cocoli, now tributary to Miraflores Lake, and chagrensis in Miraflores Lake. However, these waters are accessible to the fishes from the Chagres River (or Gatun Lake) by passing through Culebra Cut and Pedro Miguel Locks.

The El Valle specimens differ from argenteus, a species of the streams of the Pacific slope of eastern Panama, principally in having notably smaller scales. $B$. argenteus has about 43 to 48 oblique series of scales on middle of side between the margin of the opercle and base of caudal, 7 or 8 complete longitudinal rows between the lateral line and origin of dorsal, and only 3 between the lateral line and base of ventral.

Brycon argenteus Meek and Hildebrand.

Brycon argenteus Meek and Hildebrand, Field Mus. Nat. Hist., Zool. Ser., 10, p. 84, 1913-Rio Aruza, tributary of the Tuyra; ibid., p. 298, pl. 25, 1916.

This species was not among the recent collections. It is not recorded from the Canal Zone, though it has been taken in Pacific slope streams east and west of the Canal Zone, as pointed out in the discussion of $B$. petrosus, its nearest relative. A discussion of the relationship of this species is introduced here because its validity has been questioned, which led the writer to make a further study of its relationship with other species of the genus. The results of this further study, principally of specimens, are included partly in the account of $B$. petrosus and partly in the following paragraphs.

The question of the identity of this species with $B$. guatemalensis, a Central American species presumably only of the Atlantic slope, was brought up by Behre (1928, p. 318), who quotes Eigenmann: "It seems very probable that $B$. argenteus is identical with this species." I have not seen Dr. Behre's specimens, which are from the 
Atlantic drainage of western Panama, but I have examined eight specimens from Guatemala and Nicaragua in the National Museum. According to Regan's original description $(1908$, p. 168) the specimens examined apparently are all guatemalensis and certainly all specifically distinct from argenteus.

The Central American specimens differ at once in the longer anal, which is composed of 32 to 38 rays, and its base is much longer than the head, whereas argenteus has only 24 to 28 anal rays, and the base of the fin does not exceed the length of the head. Furthermore, guatemalensis has smaller scales, there being 50 to 56 in the lateral series, 9 or 10 longitudinal rows between the lateral line and origin of dorsal, and 4 or 5 between the lateral line and base of ventral, whereas argenteus has 43 to 48 scales in the lateral series, 7 to 9 rows between the lateral line and origin of dorsal, and 3 or 4 between the lateral line and base of ventral. Finally, guatemalensis seems to have smaller and more numerous teeth, the outer series in the premaxillary consisting of 16 teeth, and the outer series of mandibular teeth consisting of 10 enlarged ones followed at each side by 2 or 3 smaller ones. $B$. argenteus has 14 teeth in the outer premaxillary series, and 8 enlarged mandibular teeth.

The relationship of this species with $B$. obscurus sp. nov. is pointed out in the account of that species.

This fish is known from the Pacific slope of Panama from the Rio Chorrera to the Rio Tuyra, but not from the Canal Zone.

Piabucina Cuvier and Valenciennes.

The fishes of this genus have an elongate body, which is somewhat compressed; the teeth in the premaxillaries are in one series, and those on the mandible are in two well-separated series; all or nearly all are tricuspid; the scales are large and firm (27 to 30 in a lateral series in Panama species); the lateral line is missing; the dorsal and anal fins are short (the former with 8 to 10 rays, and the latter with 10 to 12 in Panama species); and an adipose fin is present.

Two closely related species have been recognized from Panama, namely panamensis and festae, the latter only from the Tuyra Basin. The species apparently differ chiefly in color. Both have a dark lateral band, but the one in panamensis originates above the posterior (distal) angle of the opercle, is situated on the middle of the side, and is often broken up into dark spots, whereas in festae this band begins at the posterior (distal) angle of the opercle, is below the middle of the side, is continuous (not broken up into separate spots), 
and does not end in a caudal spot as in panamensis. In festae a separate dark shoulder spot is present, which is connected with the lateral band in panamensis.

\section{Piabucina panamensis Gill. "Domini Candela."}

Piabucina panamensis Gill, Proc. Acad. Nat. Sci. Phila., p. 336, 1876-Rio Frijoles, Canal Zone; Meek and Hildebrand, Field Mus. Nat. Hist., Zool. Ser., 10, p. 300, 1916.

The principal recognition marks of this characin have already been set forth in the account under the generic name. Its usual habitat is in streams among rocks where it is easily recognized by a bright yellow, generally elongate, spot in advance of the dorsal fin. This spot is much more distinct in the water than in a fish just removed from the water, and it fades completely shortly after death. In shape, behavior, and habitat this fish resembles the brook trout somewhat. It is a rapid swimmer, darting here and there quickly for cover. As it is quick in its movements and generally stays in rocky places it is difficult to net. However, it takes the hook readily, but a wire leader is necessary, as it is able to snap a line easily with its comparatively large sharp teeth. It apparently rarely exceeds a length of $200 \mathrm{~mm}$., and therefore is too small to be of much value as food.

Its resemblance to the trout apparently has given origin to the belief (or supposition) among some Canal Zone employees that it actually is a trout, presumably introduced by the French at the time a company of Frenchmen attempted to construct an Isthmian canal. The bright yellow spot in advance of the dorsal fin, as seen in the water, appearing more or less as a light, apparently had something to do with the origin of the local name "domini candela."

During the breeding season, at least, adult males may be distinguished from the females by a thickening of the tissues surrounding the anterior simple rays of the anal. Ripe or nearly ripe fish were taken during February.

This fish evidently feeds on both animal and plant foods. A large seed, some leaves of an unidentified plant, and vegetable debris were found in the several stomachs examined. The same fish had fed also on insects, and one had ingested a small shrimp.

This species was secured during the recent investigations in the Atlantic drainage at Cativa, Fort Sherman (Toro Point), and in a small stream on Barro Colorado Island. On the Pacific side it was collected in the Rio Cocoli (flowing into Miraflores Lake) and in the 
Rio Capira near Campaña. As this fish seems to confine itself to rocky streams it probably never enters the Canal.

Eigenmann (1922, p. 126) gave as the habitat of this species, "Panama on both slopes, Atrato Basin, and San Juan Basin." If this is the correct distribution it seems singular that the species has not been taken in the Tuyra Basin, where numerous specimens of $P$. festae have been collected.

\section{Piabucina festae Boulenger.}

Piabucina festae Boulenger, Boll. Mus. Torino, No. 346, 14, p. 1, 1899Laguna de la Pita, Darien, Panama; Meek and Hildebrand, Field Mus. Nat. Hist., Zool. Ser., 10, p. 301, 1916.

Since 1916 this species has been reported from the Rio Chucunaque by Breder (1927, p. 117), who had 40 specimens ranging in length from 54 to $130 \mathrm{~mm}$. Mr. Breder stated: "There is a distinct dark spot near the bases of the fourth, fifth, and sixth dorsal rays, the fifth passing through its center, which is not mentioned in descriptions."

This species, as now understood, is known only from the Rio Tuyra Basin. In our earlier work (1916, p. 301) we gave as habitat, "Rio Tuyra Basin and southward to Colombia," believing at that time that at least the Atrato specimens were identical with those from the Tuyra. However, Eigenmann (1922, p. 126) included the specimens from the Atrato and San Juan rivers under $P$. panamensis.

\section{Ctenolucius Gill.}

Ctenolucius Gill, Senate Doc. 9, Second Sess., thirty-sixth U. S. Congress, 7, pt. 1, 1861, p. 258 (name only); Proc. Acad. Nat. Sci. Phila., 13, Suppl., p. 8,1861 .

The name Ctenolucius supersedes Luciocharax, used by us (1916, p. 302), because of the law of priority. Gill did not name a type for Ctenolucius, but Jordan sets forth the case in his "The Genera of Fishes" (pt. III, 1919, p. 302) as follows, "Ctenolucius Gill, 8; orthotype not named = Luciocharax insculptus Steind. It is described as an ally of Xiphostoma, a South American Characin, identical with Luciocharax Steind., 1876, which name it should replace." Eigenmann (1922, p. 166) accepted this decision, but questioned whether Hydrocynus hujeta (Xiphostoma hujeta Cuvier and Valenciennes, Hist. Nat. Poiss., 22 p. 358, 1848), recorded from Maracaibo, is not identical with C. insculptus.

The long, slender pike-like body, the produced, spike-like snout, and the firm pectinate scales readily distinguish the single species known from Panama from all the other local characins. 
Ctenolucius beani (Fowler).

Belonocharax beani Fowler, Proc. Acad. Nat. Sci. Phila., p. 464, 1906-Rio Truando, tributary of the Rio Atrato.

Luciocharax beani Meek and Hildebrand, Field Mus. Nat. Hist., Zool. Ser., 10, p. $302,1916$.

This species, which is the only one of the genus occurring in Panama, differs so greatly from all other fresh-water fishes, as already stated in the generic account, that it is readily recognized. It is known only from the Pacific slope in Panama from several streams east of the Canal Zone, but not from the Zone itself. During the recent investigations it was taken only in a swamp at the La Jagua Hunting Club.

A related species, $C$. insculp'us, occurs in the Magdalena Basin, Atlantic slope of Colombia, differing principally in the absence of the dark stripes between the rows of scales along the sides. Generally the incomplete lateral line is present on fewer scales in that species than in C. beani, 17 to 28 scales having pores in the Magdalena fishes, whereas in the other species pores are present on 27 to 39 scales. The Panama fish seems to prefer standing or sluggish water. It reaches a maximum length of about $325 \mathrm{~mm}$.

Breder (1927, p. 128) found C. beani abundant at several places in the Chucunaque Basin. In 78 stomachs examined he found only fish and decapod crustaceans, indicating that the fish are wholly carnivorous, as suggested by the very short intestinal canal.

This characin is recorded from the Pacific slope of central and eastern Panama to the San Juan River in Colombia, and from the Atrato Basin of the Atlantic slope in Colombia.

\section{Hoplias Gill.}

The elongate, scarcely compressed body; the rather large mouth with strong teeth, some of them canines; the short dorsal and anal fins (D. 13 to 15 ; A. 10 or 11); and the absence of an adipose fin characterize this genus.

Two closely related species are known from Panama, namely, microlepis and malabaricus. These usually differ in the number of rows of scales, the former having 11 rows across the caudal peduncle from the lateral line on one side to the one on the other, and 5 complete rows between the lateral line and the base of anal, whereas the latter has 9 rows across the peduncle and only 4 between the lateral line and the base of anal. Some evidence indicating that the two intergrade has been found (Breder, 1927, p. 129). 


\section{Hoplias microlepsis (Günther). Pesca PERRo; PejePerro.}

Macrodon microlepis Günther, Cat. Fish. Brit. Mus., 5, p. 282, 1864-Rio Chagres and western Ecuador.

Hoplias microlepis Meek and Hildebrand, Field Mus. Nat. Hist., Zool. Ser., 10 , p. $303,1916$.

This species is easily distinguished from other Panama fishes exclusive of the closely related one occurring in the Tuyra Basin and southward, mention of which was made in the account under the generic name. The elongate, rather robust body, which is scarcely compressed; the large mouth with strong teeth; the short dorsal with only 13 or 14 rays, placed over the mid-length of the back; the short anal with only 10 or 11 rays; the absence of the adipose fin; and the general dark brown to smutty color above, serve to characterize the species. It is common in lowland streams and swamps on both slopes of Panama, west of the Tuyra Basin. It is commonly found in still shallow water among vegetation, where it seemingly hides waiting for its prey, as it no doubt is a highly predatory species. It has acquired its common names, namely, "pesca perro" and "pejeperro," from its large teeth and the habit of snapping dog-like at anything coming near. If care is not taken it will wound the hands severely when picked up after being caught in a net. The species reaches a length of about 46 to 50 $\mathrm{cm}$., but it is not valued as food, being eaten sparingly.

It is very common on both slopes of central Panama, and according to Eigenmann (1922, p. 169) also on the Pacific slope of southern Ecuador. It is not reported from western Panama. During the recent investigations it was not secured in the Rio Cocoli nor Miraflores Lake, though it doubtless occurs there. It was taken at Barro Colorado Island; in the upper end of Gatun Lake near Madden Dam, and in a small creek near the same place. This species seems to be less numerous in the Gatun and Miraflores lakes areas than it was before the opening of the Canal. It was very abundant in the swamps near the La Jagua Hunting Club in 1935, when some rather large individuals were taken and offered to a native, who refused them, saying they were no good.

\section{Hoplias malabaricus (Bloch).}

Esox malabaricus Bloch, Naturgesch. der Ausland. Fische, pt. 8, p. 149, pl. $392,1794$.

Hoplias malabaricus Meek and Hildebrand, Field Mus. Nat. Hist., Zool. Ser., 10, p. 305, 1916.

This species has been recorded from 15 specimens from the Chucunaque Basin by Breder (1927, p. 129) since the publication 
of our earlier (1916) work. The relationship of this species and the preceding one is discussed in the account of the genus.

The range is given by Eigenmann (1922, p. 170) as extending from the Tuyra Basin in Panama south to the Patía (southern Colombia) on the Pacific slope, and from the Atrato Basin in Colombia to Buenos Aires on the Atlantic slope.

\section{Family GYMNOTIDAE}

\section{Gymnotus carapo Linnaeus.}

Gymnolus carapo Linnaeus, Syst. Nat., Ed. 10, 1, p. 246, 1758; Meek and Hildebrand, Field Mus. Nat. Hist., Zool. Ser., 10, p. 307, 1916.

An account of this species, not then known from Panama, was included in our earlier work $(1916$, p. 307) because it was recorded from both north and south of Panama. Behre (1928, p. 310) reported two specimens from a small stream flowing into Almirante Bay, Atlantic slope of extreme western Panama, which is the only record from Panama known to me.

The general range of this gymnotid eel extends from Guatemala (both slopes) to Colombia (both slopes) and southward east of the Andes to Rio de la Plata.

Sternopygus dariensis Meek and Hildebrand.

Sternopygus dariensis Meek and Hildebrand, Field Mus. Nat. Hist., Zool. Ser., 10, p. 309, pl. 26, 1916.

This eel, first taken in the lower Tuyra (Meek and Hildebrand, 1916 , p. 309) in a very muddy tidal creek, where it was numerous, was later reported from El Real de Santa María, still lower down on the Tuyra, and from two localities in the lower part of the Chucunaque Basin (Breder, 1927, p. 130). It was not seen during the recent investigation.

This species is known to date only from the material already mentioned from the lower part of the Tuyra and Chucunaque rivers.

Hypopomus brevirostris (Steindachner).

Rhamphichthys brevirostris Steindachner, Sitzber. Akad. Wiss. Wien, 58, p. 254, pl. 2, fig. 2, 1868 - Guaporé.

Hypopomus brevirostris Meek and Hildebrand, Field Mus. Nat. Hist., Zool. Ser., 10, p. 310, 1916.

This species was reported in our earlier work (1916, p. 310) from two specimens from the Chagres Basin and two from the Bayano. Since that time Breder (1927, p. 130) has reported four specimens from the Chucunaque Basin, and Behre (1928, p. 309) 
recorded 47 specimens from the Rio Cricamola, Atlantic slope of western Panama.

It occurs in rivers on both slopes of Panama and Colombia, and apparently east of the Andes to Paraguay.

Eigenmannia virescens (Valenciennes).

Sternarchus virescens Valenciennes, in d'Orbigny, Voy. Amér. Mérid., 5, pt. 2, p. 11 , pl. 13, fig. 2, 1847 .

Eigenmannia virescens Meek and Hildebrand, Field Mus. Nat. Hist., Zool. Ser., 10, p. 311, 1916.

This species is not in the recent collections. We secured only two specimens in 1911 and 1912. These were taken at Marrigante, in the Tuyra, below the head of tide water. It is reported also from the Rio Mamoni, near Chepo, by Steindachner (1879, p. 169) under the name Sternopygus humboldtii, a record overlooked by us when preparing our earlier work.

The range as now understood extends from the Rio Mamoni and the Rio Tuyra in Panama to the Rio Magdalena in Colombia and southward to Buenos Aires.

Sternarchus rostratus Meek and Hildebrand.

Sternarchus rostratus Meek and Hildebrand, Field Mus. Nat. Hist., Zool. Ser., 10, p. 85, 1913-Rio Grande near Cana, Panama; p. 312, pl. 27, 1916.

This gymnotid eel is known from Panama only from the type, taken in the Rio Grande, an upper tributary of the Tuyra River. Eigenmann (1922, p. 176) recorded several specimens from the Rio Magdalena on the Atlantic slope of Colombia.

\section{Family SYNBRANCHIDAE}

\section{Synbranchus ${ }^{1}$ marmoratus Bloch.}

Synbranchus marmoratus Bloch, Ichthyol., 9, p. 87, pl. 418, 1795; Meek and Hildebrand, Field Mus. Nat. Hist., Zool. Ser., 15, p. 131, 1923.

Six specimens are at hand, ranging in length from 93 to $345 \mathrm{~mm}$. Five of these, all small, 93 to $120 \mathrm{~mm}$. long, are from a lily pond at Summit, Canal Zone, where the species was reported numerous, and one is from an unknown number of miles west of Balboa. The largest specimen was presented by G. O. Lee, head of the department of biology of the junior college at Balboa, and the others were obtained through the interest and kindness of employees of the botanical station at Summit.

${ }^{1}$ Spelling has been corrected to Symbranchus by Eigenmann (1922, p. 177) and some other writers. 
Breder (1927, p. 131) listed 12 specimens, eight from the Rio Sucubtí, tributary of the Chucunaque, three from the Rio Tapia, near Panama City, and one from Caledonia on the Atlantic. Mr. Breder stated that he always found this eel buried under sand or rocks, which explains why it is not taken in seines. He said, also, that calcium carbide used as poison brought the eels out in great numbers in the Sucubtí. These fish probably are nocturnal, as it is not reasonable to suppose that they always lie buried. Gilbert and Starks (1904, p. 34) stated that they were so abundant in a pond at Miraflores, Canal Zone, that they were trapped for food, yet none could be taken with a seine. This species was reported also from Barro Colorado Island, Canal Zone, by Breder (1933, p. 567).

Breder (1927, p. 131) found the eels both above and below falls in the Rio Sucubtí, which "held back all the other normal river fauna." In explanation he advanced the supposition that the eels probably go overland, through wet grass, around the falls.

This species is not listed in our earlier work (1916) on the freshwater fishes of Panama, as it was overlooked. However, a description is given in a later publication (1923, p. 131). This description was emended by Breder (1927).

This eel stands in a family by itself, having no near relatives, so far as known. It is readily recognized by the very long body, which greatly exceeds the tail in length; the projecting snout; the rather large mouth, reaching far beyond the eye; the small confluent gill openings, situated on the median ventral line; and the absence of pectoral and ventral fins. The low, membranous dorsal begins a short distance in advance of the vent, and is confluent around the tail with the scarcely developed anal. The color is reported variable. The small specimens at hand are grayish, lighter below than above, the lighter areas underneath being finely dotted with the darker gray of the back. The large specimen is dark brown above, and the grayish under parts are definitely marked with numerous small brownish spots.

The following proportions are based on measurements of the six specimens in the present collection. Tail in head and trunk 2.9 to 3.1 ; head to gill opening in head and trunk 6 to 6.4 ; depth in head 2.5 to 3 ; eye about 10 to 16 ; snout 6.4 to 6.7 ; gape from its posterior angle to tip of upper jaw 2.5 to 3.1 .

This eel is widely distributed, ranging from southern Mexico to the Amazon and probably southward. It has been taken on both slopes of central and eastern Panama. 


\section{Family ANGUILLIDAE}

Anguilla rostrata (Le Sueur). COMMON FRESH WATER EEL; "ANGUILla."

Muraena rostrata Le Sueur, Journ. Acad. Nat. Sci. Phila., 1, p. 81, 1817New York.

Anguilla rostrata Meek and Hildebrand, Field Mus. Nat. Hist., Zool. Ser., 15, pt. 1, p. 134, 1923.

This species is not listed in our earlier work (1916) because it was overlooked. It is recorded, however, in our work on the marine fishes of Panama (1923, p. 134) from one specimen from the Trinidad River, where it was not rare in 1911 according to native fishermen. Whether it is able to reach this stream since the construction of Gatun Dam has not been determined. If it cannot get by the spillway, it should have no difficulty going through the locks, though no specimens were taken when the locks were dewatered in 1935, and none in Gatun Lake nor tributary streams. Since our earlier investigation it has been reported, however, from nine specimens taken in small streams flowing into Almirante Bay, on the Atlantic slope of extreme western Panama by Behre (1928, p. 310), and Breder (1925, p. 140) listed young ones from the foot of Gatun Spillway, Canal Zone. It has been recorded also from Caldera Island, Porto Bello Bay by Evermann and Goldsborough (1909, p. 101).

The single genus and species of this family occurring in American waters is recognized by the snake-like body, which is covered with scales that are linear, embedded, and arranged in groups placed more or less at right angles to each other. The lower jaw projects somewhat; the gill openings are separate and lateral, partly in front of the base of the pectoral fins; and the dorsal fin begins in advance of the anal a distance nearly equal to the length of the head. The color is uniform greenish above and pale below.

Breeding takes place in deep water at sea. The larvae, generally known as leptocephali, are not eel-like, but are soft, more or less ribbon-shaped transparent creatures with a rather large mouth and large teeth. After spending a year or so in the sea, a metamorphosis takes place, and the young ascend fresh-water streams.

The general range of the common fresh-water eel extends from southern Canada, through the West Indies, to Panama. Species of the genus Anguilla occur in nearly all warm seas and adjacent streams, exclusive of the eastern Pacific. 


\section{Family POECILIIDAE. Viviparous Top-minnows}

The members of this family are viviparous and are characterized by an oblong body, which is more or less depressed anteriorly. compressed posteriorly, and covered with rather large cycloid scales, The head is flat above, the mouth is protractile, the dorsal fin is single and consists of soft rays only, the ventral fins are abdominal, and the anal fin in adult males is variously modified to form an intromittent organ or gonopodium.

As formerly understood this family included many oviparous genera, which have been assigned to a separate family, Cyprinodontidae, by recent authors. Only one genus belonging to the oviparous group, Rivulus, occurs in Panama. This genus was placed in the Poeciliidae in our earlier work $(1916$, p. 330$)$, but is now dealt with separately under the family Cyprinodontidae.

The classification of Hubbs (1924 and 1926) has been followed for the most part. The use of the structure of the intromittent organ (gonopodium) as the principal and often the sole character for generic divisions in these papers has led, in my opinion, to too great a multiplication of genera. This classification makes it difficult at times to separate females of different genera, as pointed out subsequently. It is not the purpose of this paper to carry out generic revisions, but it is apparently proper to state (after having examined and used the classification referred to rather extensively) that it would seem more logical, and that it would simplify classification, if these minnows were grouped generically with reference to the general type of gonopodium, in combination with other characters that would aid in grouping the females also.

The counts of fin rays for the members of this family include the simple rays, which are not shown separately.

The members of this family have proved the most valuable among fishes as enemies of the mosquito. Unfortunately, those species in Panama that seem best suited to cope with the mosquito have not established themselves in abundance, as shown by collections and observations, in the artificial lakes of the Panama Canal. The only minnow of this family that has become very numerous in the lakes is Mollienisia sphenops, and it is apparently of limited value, as pointed out in the account of that species.

Gambusia Poey.

A single species of this genus occurs in Panama if the structure of the intromittent organ (gonopodium) is used as a basis for defining 
genera. In the present genus this organ is provided near the tip with two rather strong spiny hooks, directed backward and downward. This structure is shown for G. nicaraguensis in a camera lucida tracing by Meek and Hildebrand (1916, p. 316, fig. 4).

The close relationship of $G$. nicaraguensis and Brachyrhaphis cascajalensis is pointed out in the following account, which shows that closely related species sometimes fall into different genera if the gonopodium is used as the sole basis for founding genera.

\section{Gambusia nicaraguensis Günther.}

Gambusia nicaraguensis Günther, Cat. Fish. Brit. Mus., 6, p. 336, 1866Lake Nicaragua; Meek and Hildebrand, Field Mus. Nat. Hist., Zool. Ser., 10, p. 316, 1916.

Many specimens of this top minnow were collected on Largo Remo Island, at Fort Sherman (Toro Point), Mount Hope Dry Dock, and in Gatun Lake near Gatun and at Barro Colorado Island. In general, this species seems to run smaller in size than Brachyrhaphis cascajalensis, with which it sometimes associates and which it resembles greatly. The largest female taken is $45 \mathrm{~mm}$., and the largest male $37 \mathrm{~mm}$. long. In some males the intromittent organ is developed at a much smaller size than in others. For example, a fully mature male only $20 \mathrm{~mm}$. long is at hand, whereas another equal in length to the largest male taken $(37 \mathrm{~mm}$.) is not yet fully mature, as the anal fin though considerably modified still does not possess the characteristic hooks of a mature male.

This species, as already suggested, is very similar to $B$. cascajalensis, with which it agrees in the shape of the head and body, the position of the dorsal fin, and the number of scales in a lateral series. However, nicaraguensis seems to have 1 or 2 more series of scales between the upper angle of the gill opening and the origin of the dorsal, 14 to 16 being present, whereas only 12 or 13 were counted in cascajalensis. Both species have a broad depressed snout, that has the appearance of having been squeezed to a sharp edge between a man's fingers. Adult males are readily distinguished by the differences in the structure of the intromittent organs, that of nicaraguensis being provided with distinct hooks distally, which are wanting in cascajalensis. The differences are figured by Meek and Hildebrand in camera lucida tracings. (1916, p. 316, fig. 4, and p. 318, fig. 5. Although fig. 5 is based on B. episcopi it is representative of cascajalensis, as the two are identical in that respect.) The species also differ somewhat in color. G. nicaraguensis often has black dots on the upper part of the sides, forming rows along the 
series of scales. Similar dots occur on the dorsal and caudal fins, usually forming more or less distinct crossbars. The anal fin is not blotched with black at the base, as in B. cascajalensis.

The number of young born at one time seems to be rather small, as in three females examined, respectively 39,35 , and $32 \mathrm{~mm}$. long, the broods consisted of 10,10 , and 4 large embryos in addition to a similar number of large yellow eggs and two or three smaller sets of eggs. No evidence of the development of embryos in a second clutch of eggs before the older embryos are born was seen, as in some of the other local species of this family. The young are well developed, pigmented, and comparatively large when born, as embryos with nearly all the yolk absorbed are about $7 \mathrm{~mm}$. long.

The intestinal tract is very short. Three stomachs examined contained fragments of insects only. This is probably the most useful minnow in Gatun Lake as a natural enemy of the mosquito. It was not secured in Miraflores Lake.

This species ranges on the Atlantic coast from Mexico to Panama and is doubtfully recorded from the Pacific slope of Panama. It inhabits lowland streams and sometimes decidedly brackish to salty water, though it ranges well up into fresh water as shown by its presence in Gatun Lake. On the other hand, the water in the Mount Hope Dry Dock, where it also was taken, is decidedly salty. It is an exceedingly hardy fish, as shown by the survival of a dozen or so individuals confined to a small (about a quart size) can for a period of three days without artificial aeration and without a change of water, whereupon they were placed in a small aquarium in apparently good condition. According to reports received, they lived there for months and multiplied.

Breder (1933, p. 567) listed Gambusia affinis speciosa Girard from Barro Colorado Island, Canal Zone, with the remark: "This species is the Gambusia nicaraguensis from Panama of authors. Hubbs and Gordon (MS.) identify this fish with the race speciosa of G. affinis, native of northeastern Mexico and central Texas. Consequently, the present species must be an introduction from early Canal building days for the purpose of mosquito control." I have compared the recently collected specimens from Panama, together with others collected there, by us in 1911 and 1912, with specimens of Gambusia from various sections of the United States from New Mexico to the Atlantic coast. None of the males examined from the States have long prominent serrae on the third anal ray like the Panama material. The gonopodium in the Panama speci- 
mens before me agrees with the figures given by Hubbs (1926, pl. 2, figs. 1,2, and 3) for G. nicaraguensis, as well as with the figure in our work (1916, p. 316, fig. 4). The Panama specimens, also, are more distinctly marked than the States material, the rows of scales on the sides, at least posteriorly, being rather definitely marked with rows of black dots. Similar dots are prominent on the dorsal and caudal fins also, where they form cross lines. It seems improbable, on the basis of this study, that the Panama material before me is the progeny of an importation. Since writing the foregoing statements concerning the introduction of minnows, I have communicated with Mr. J. A. Le Prince, chief sanitary inspector for the Isthmian Canal Commission from 1904 to 1914 . Mr. Le Prince informs me that he knows of only one importation of top minnows, namely, the "millions fish" (Lebistes reticulata), which was brought from Barbados, and released in several places now within Gatun Lake. A further discussion of this importation has been given (see p. 225).

\section{Brachyrhaphis Regan.}

This genus is characterized by the rather short intromittent organ (gonopodium), which is rather less than a third of the standard length, and which is very simple in structure, having no hooks or spines, as shown by Meek and Hildebrand (1916, p. 318, fig. 5). The body, mouth, and dentition are very similar to Gambusia, under which episcopi and cascajalensis were placed in our earlier publication.

The principal distinguishing characters of the three species collected are pointed out in the accounts that follow.

Brachyrhaphis episcopi (Steindachner).

Gambusia episcopi Steindachner, Sitzber. Akad. Wiss. Wien, 77, p. 387, pl. 2, figs. 3, 4, 1878-Obispo, Canal Zone; Meek and Hildebrand, Field Mus. Nat. Hist., Zool. Ser., 10, p. 317, fig. 5, 1916.

This top minnow, although seemingly fairly common in central Panama during our earlier (1911 and 1912) investigations, was taken in only three places recently; namely, in the Rio Capira at Campaña, in a small creek in El Valle, and in a cloudy pool remaining in a dry creek crossing the road shortly before entering El Valle. This fish alone inhabited the pool mentioned, where it was numerous. Some of the females were larger than any seen previously, the largest one being $64 \mathrm{~mm}$. long. The males, as usual among viviparous fishes, were greatly in the minority, and much smaller, the largest one having a length of only $30 \mathrm{~mm}$. 
This species is recognized principally by the greenish color in life, and the black spots along the middle of the side, which may be quadrate, or vertically somewhat elongate, and which in nearly all the specimens from near El Valle are united on the posterior half or two-thirds of the body, forming a continuous black lateral band.

The number of young in a brood seems to be small, but the broods probably are born at short intervals. For example, a female, $33 \mathrm{~mm}$. long, with a greatly distended abdomen, contained 8 large embryos with little yolk, and 12 smaller ones, already in the "eyed" stage, besides eggs of at least three different sizes. Another female, $40 \mathrm{~mm}$. long, but with the abdomen less distended than the one already mentioned, contained only 4 eggs with embryos, and 4 very large eggs without embryos, besides 3 or 4 sets of smaller eggs.

The intestinal tract is very short. The contents of two stomachs examined consisted of insect fragments. This fish probably is of value as a destroyer of mosquito larvae. Unfortunately it does not seem to have established itself in abundance in the artificial lakes of the Canal. Although Hubbs (1926, p. 47) reported "numerous specimens" from Gatun Lake, Barro Colorado Island, I did not take this fish there in two days of seining. I failed also to get it at several other places in Gatun Lake where collections were made, as well as in Miraflores Lake.

This species, unlike its near relative, $B$. cascajalensis, seems to avoid brackish water, confining itself chiefly to somewhat higher -altitudes. It is reported from both slopes of central Panama, but not from the Bayano or Tuyra basins. On the Pacific slope of western Panama it is replaced by $B$. terrabensis.

\section{Brachyrhaphis cascajalensis (Meek and Hildebrand).}

Gambusia cascajalensis Meek and Hildebrand, Field Mus. Nat. Hist., Zool. Ser., 10, p. 86, 1913-Rio Cascajal, Porto Bello, Panama; p. 318, 1916.

Specimens were collected at Puerto Pilón; Cativa; Largo Remo Island; Fort Sherman (Toro Point); in Gatun Lake at Gatun and Barro Colorado Island; and in a creek tributary to Gatun Lake, on the Madden Dam Road. In general the specimens run larger in size than those of Gambusia episcopi. Females of $50 \mathrm{~mm}$. or more in length, and males $30 \mathrm{~mm}$. and upward are common, the largest female taken being $63 \mathrm{~mm}$. and the largest male $37 \mathrm{~mm}$. long.

This species has a rather more slender body than episcopi, as pointed out by us (1916, p. 318). The dorsal fin is more posteriorly placed, and apparently has fewer rays, its origin in females being 
over the end of the base of the anal instead of over the middle of the anal, as in episcopi. The number of rays is constantly 7 in 19 specimens, whereas in episcopi this fin has constantly 8 rays according to 18 specimens examined, if in each species the last partly divided ray is counted as one. Furthermore, the dorsal profile is nearly straight in advance of dorsal instead of notably convex, as in episcopi. B. cascajalensis also is plainer in color, being grayish and without a lateral band or lateral spots, except in a few small specimens which have faint dark spots. The black on the anal is generally more prominent and spreads over more of the fin.

The intestinal tract is as short as in episcopi. Two specimens examined had fed on insects. The species no doubt feeds on mosquito larvae if available, and where numerous enough it probably provides a degree of mosquito control. Although taken in two places in Gatun Lake it did not seem to be numerous, and it was not found in Miraflores Lake. Therefore, it seems to be too rare in the artificial lakes of the Canal to be of much value in controlling mosquito-breeding.

Comparatively large broods of young are apparently produced by large females, as a specimen $58 \mathrm{~mm}$. long contained 49 large embryos. These embryos had absorbed nearly all the yolk and were pigmented almost like the adults. Therefore, they were, no doubt, about to be born. However, no other eggs with embryos were present in this specimen, nor in a smaller one examined, as found in several other species of this family here reported. The smaller female, $43 \mathrm{~mm}$. long, contained only 13 large embryos, besides eggs of two or three different sizes.

During the recent investigation this species was taken only in the Atlantic drainage. Earlier (1911 and 1912), a few specimens were taken in the Pacific drainage of central Panama. It was not secured in the Bayano nor Tuyra basin. Hubbs (1926, p. 47) reported it from pools and shallows in the Rio Nargana, a few miles from the Caribbean Sea, San Blas, Panama. He reported it also from several localities in the Caribbean drainage on both sides of the Panama-Costa Rica boundary. The last-mentioned record was based on specimens collected by Behre, which she also reported (1928, p. 315). This species, therefore, appears to inhabit the Atlantic slope of all of Panama and part of Costa Rica. It seems to be most numerous in lowland pools and streams, occurring at times in brackish water. 


\section{Brachyrhaphis terrabensis (Regan).}

Gambusia terrabensis Regan, Ann. Mag. Nat. Hist. (7), 19, p. 260, 1907; Biol. Cent. Amer., Pisces, p. 97, pl. 12, fig. 7, 1907-Rio Grande de Térraba, Pacific slope, Costa Rica.

Specimens were collected in a muddy trickle on a mountain side, a short distance from the Rio Chiriquí Viejo, at an elevation of about 5,000 feet, in water less than an inch deep. No native fishes were seen above this elevation in that river basin, which was explored to an altitude of about 7,000 feet. Very brightly colored specimens were collected in quiet places in the clear water of the Rio Barilles (tributary of the Rio Chiriquí Viejo) at an elevation of about 4,800 feet. Others were taken in the near-by lagunas Gulnar and Grande at about the same altitude. The largest female taken is $49 \mathrm{~mm}$. and the largest male has the relatively great length of $42 \mathrm{~mm}$.

In shape of body and color, this species is similar to Gambusia episcopi. It is readily separable from that species, as well as from Brachyrhaphis cascajalensis, by the longer dorsal fin, which has 13 rays. Its origin also is farther forward, being in advance of the anal in females. Because of the more anterior position of the dorsal only 8 or 9 series of scales are present between the upper angle of the gill opening and the origin of the dorsal, whereas 12 or 13 series may be counted in the other two Panama species of the genus.

$B$. terrabensis is known only from the Pacific slope of western Panama and from Costa Rica. In addition to the specimens already listed here, Hubbs (1926, p. 43) recorded specimens from the upper part of the Rio Chiriquí del Tire Basin, and others from the vicinity of Boquete. These specimens also in part were listed by Behre (1928, p. 315). Still others from the same general vicinity of Panama were recorded by Hildebrand (1928, p. 83).

\section{Trigonophallus Hubbs.}

This genus seems to be close to Brachyrhaphis. It is described by Hubbs (1926, p. 48) in part as follows: "This organ (gonopodium) is longer than in Brachyrhaphis, being decidedly more than one-third as long as the fish (to caudal fin). The extreme membranous tip is peculiarly hardened and modified into a subtriangular structure, the free tips of which are pointed outward and backward. The distal segments of ray 3 , as in neither of the related genera, are produced posteriorly as definite pointed spines. The tips of rays 4 and 5, as in most of the species here referred to Brachyrhaphis, are slightly turned backward." 


\section{Trigonophallus punctifer Hubbs.}

Trigonophallus punetifer Hubbs, Misc. Pub. Mus. Zool., Univ. Michigan, No. 16, p. 49, 1926-Guibari Creek, tributary of Rio Cricamola, Atlantic slope, western Panama.

This species is known only from the type, a male $30 \mathrm{~mm}$. long, and some female paratypes, 27 to $51 \mathrm{~mm}$. long, collected in a tributary to the Rio Cricamola and in the Rio Cricamola, both near Conquantu, and in the upper course of Western River, flowing into Almirante Bay, all from the Atlantic slope of western Panama. The type specimens are recorded also by Behre (1928, p. 316), who collected them. The species was not seen by me. The following description is condensed after Hubbs.

Body moderately deep, rather sharply compressed posteriorly; dorsal contour almost straight from snout to occiput, from there to dorsal moderately convex; tail bent downward dorsally; head 3.3 to 3.7 ; depth 3 to 3.4 ; snout 2.8 to 3.35 in head; eye 2.7 to 3.6 ; interorbital 1.9 to 2.5 ; caudal peduncle 1.6 to 1.9 ; mouth partly lateral, the cleft extending more than halfway to eye; maxillary reaching vertical from anterior margin of eye; symphysial knob of mandible protruding beyond upper jaw; teeth firmly fixed, sharply conical, in bands of moderate width, the outer ones enlarged; scales 28 or 29 from upper angle of gill opening to base of caudal; dorsal with 10 or 11 (rarely 9) rays, its origin nearly equidistant from tip of snout and end of middle rays of caudal; caudal truncate; anal with 9 rays (including unbranched ones), its origin slightly in advance of dorsal; ventrals not modified in males; pectoral rounded, 1.3 to 1.5 in head.

Color pale, with a suffusion of dark behind pectorals and on top of head; upper lip blackish; margin of mandible dusky; scale pockets on back and sides narrowly margined with dusky, the dark often intensified at apex, forming inconspicuous rows of dots. Dorsal fin with a row of vertically elongate spots on the membranes near the base, the outer posterior angle of fin dark; caudal dusky, especially toward margin; anal with a submedian blackish blotch.

This species according to the published account seems to resemble Brachyrhaphis cascajalensis and B. episcopi. It differs from both, however, in the somewhat more numerous dorsal rays, approaching $B$. terrabensis in that respect. In the dark dots on the body it resembles Gambusia nicaraguensis, which contrary to the present species also has dark points on the dorsal and caudal fins. In the black blotch on the anal fin and the dark spots near the base of 
the dorsal it seems to agree with the species of Brachyrhaphis here discussed.

\section{Allogambusia Hubbs.}

Allogambusia Hubbs, Misc. Pub. Mus. Zool., Univ. Michigan, No. 13, p. 8, 1924 ; No. 16, p. 56, 1926 (type Gambusia tridentiger Garman).

This genus is described by Hubbs as follows: "Ray 3 (of gonopodium) with a short, suberect, curved spur near tip; anterior branch of ray 4 with a much enlarged node somewhat resembling the 'elbow' of the Gambusiini."

Each jaw has an outer rather close-set series of teeth, followed by a definite band of minute ones; intestinal tract shorter than body; vertebrae about $13+19$; intromittent organ (gonopodium) 2.4 to 2.7 in standard length.

The genera Allcgambusia, Darienichthys, and Panamichthys were all carved out of the genus Priapichthys as understood by Meek and Hildebrand (1916, p. 319). Therefore, the descriptions of the species, now placed in the three later genera, appear under the genus Priapichthys in the earlier work.

\section{Allogambusia tridentiger (Garman).}

Gambusia tridentiger Garman, Mem. Mus. Comp. Zool., 19, p. 89, pl. 4, fig. 10, 1895, teeth only-Isthmus of Panama.

Priapichthys tridentiger Meek and Hildebrand, Field Mus. Nat. Hist., Zool. Ser., 10, p. 320, fig. 6, 1916.

Many specimens of this species, ranging from 9 to $35 \mathrm{~mm}$. in length, were preserved. The species was taken on the Pacific slope at El Valle; in coastal streams between Campaña and La Venta; Rio Capira at Campaña; creek at Albrook Landing Field; Rio Cocoli; Rio Pacorá; and in swamps at the La Jagua Hunting Club. On the Atlantic side it was secured in Madden Lake at the mouth of the Boquerón; in a creek on Madden Dam Road, flowing into Gatun Lake; and in an abandoned reservoir at Mount Hope. This fish is numerous in some places, as in the swamps near the La Jagua Hunting Club. It does not seem to have established itself in the artificial lakes of the Canal, as it was not secured either in Gatun or Miraflores Lake. Madden Lake had just been formed when the specimens were collected at the mouth of the Boquerón, February 12,1935 . This species was not seen in any of the locks of the Canal when dewatered in 1935 and 1937.

The males are recognized readily by the long intromittent organ with its prominent spur near the apex, visible under comparatively 
low magnification. The peculiar structure of this organ is shown in figure 6 by Meek and Hildebrand (1916, p. 321). The females, however, are sometimes not readily distinguishable from those of Darienichthys dariensis (Priapichthys dariensis in Meek and Hildebrand, 1916, p. 321). In general, the females of the present species have more prominent dark bars, but some specimens are scarcely distinguishable by the color. However, the dorsal fin is constantly a little more anteriorly placed in tridentiger, wherein its origin is over or slightly in advance of the base of the last ray of the anal, whereas in dariensis the origin of the dorsal is always somewhat posterior to the end of the base of the anal. Although the lateral series of scales is almost identical in number in these species, there is a difference in the number of scales in advance of the dorsal, due to the difference in position of the fin, tridentiger having 14 or 15 series of scales between the upper angle of the gill opening and the origin of the dorsal, whereas dariensis has 17 or 18 . The difference in the number of scales in advance of the dorsal also prevails in adult males, in which the anal fin is situated far in advance of the dorsal in both species. The differences in scale counts and position of the dorsal fin are not shown in our earlier publication (1916).

It is unfortunate that this fish does not seem to have established itself in the artificial lakes of the Canal, as it is undoubtedly an enemy of the mosquito; first, because it lives in quiet waters where mosquitoes ordinarily breed; and, second, because it feeds on insect larvae, as shown by four intestinal tracts examined.

The difference in size at which the anal fin of the male becomes fully modified and ready to serve as an intromittent organ is comparatively great for such a small fish. Males fully mature at a length of $16 \mathrm{~mm}$. have been observed, whereas others at a length of $22 \mathrm{~mm}$. are still immature. In this species, as in many others of this family, the male is much smaller than the female, the largest male in the present collection being $25 \mathrm{~mm}$. long, whereas the largest female has a length of $35 \mathrm{~mm}$., though a female $45 \mathrm{~mm}$. long has been reported.

The young are born at a comparatively large size, fully scaled, and pigmented. Young $6 \mathrm{~mm}$. long were removed from the parent. These fish were fully scaled, and had the color of young free-swimming fish, including a dark lateral line and a black spot on the middle of the side above the base of the anal. Apparently the broods are rather small, but seemingly are born in quick succession. The largest number of embryos found, in four specimens dissected, 
was 17 in a female $35 \mathrm{~mm}$. long, whereas a female $22 \mathrm{~mm}$. long contained only 6 . One specimen containing large embryos, which had absorbed nearly all the yolk and were undoubtedly about to be born, also contained a set of eggs with smaller, but well-formed embryos, besides less mature eggs. Eggs in at least three different stages of development were present in all examples examined.

The range of this species, so far as known, is limited to the Atlantic and Pacific slopes of central and eastern Panama, or to central Panama, if Allogambusia cana (Meek and Hildebrand) from the Tuyra Basin is a distinct species, as considered by Breder (1927, p. 133).

\section{Darienichthys Hubbs.}

Darienichthys Hubbs, Misc. Pub. Mus. Zool., Univ. Michigan, No. 13, p. 8, 1924; No. 16, p. 61, 1926 (type Gambusia dariensis Meek and Hildebrand).

This genus is described by Hubbs as follows:"Gonopodium rather short, between two-fifths and one-third standard length of body; process at tip of ray 3 more or less retrorse to axis of gonopodium; serrae of posterior branch of ray 4 weak (but more numerous than shown in Meek and Hildebrand's figure)."

Each jaw has an outer series of close-set teeth, followed by a more or less definite band of very minute teeth; intestinal tract very short, not as long as body; vertebrae about $13+20$; intromittent organ (gonopodium) 2.7 to 2.9 in standard length.

Darienichthys dariensis (Meek and Hildebrand).

Gambusia dariensis Meek and Hildebrand, Field Mus. Nat. Hist., Zool. Ser., 10, p. 88,1913 -Rio Capetí, tributary of the Tuyra.

Priapichthys dariensis Meek and Hildebrand, Field Mus. Nat. Hist., Zool. Ser., 10, p. 321, fig. 7, 1916.

This fish was taken in only two collections during the 1935 and 1937 investigations, namely, those from coastal streams between Campaña and La Venta, and from the Rio Pacorá. Fifty-three specimens, ranging in length from 12 to $38 \mathrm{~mm}$., are at hand.

Although this species has been considered generically distinct by some recent writers, the females are not always easily distinguishable from Allogambusia tridentiger, as pointed out in the account of that species. The males are readily distinguishable by the structure of the intromittent organ. In the present species one of the segments of a produced ray is recurved and directed forward, as shown by Meek and Hildebrand (1916, p. 322, fig. 7). Although the females generally are plainer in color than those of $A$. tridentiger, 
often having no crossbars, the males have more numerous and more distinct dark bars in the present species. The larger number of rows of scales between the upper angle of the gill opening and the origin of the dorsal, which is 17 or 18 , is generally sufficient to separate this species from $A$. tridentiger. Then, too, in females the relative position of the dorsal and anal is different, for in the present species the dorsal begins well behind the end of the base of the anal, whereas in tridentiger it begins over or very slightly behind the base of the anal. The differences just mentioned are not included in our earlier publication.

This species is known only from the Pacific slope of central and eastern Panama. In earlier investigations it was taken only in the Rio Juan Diaz, Rio Bayano and Rio Tuyra. The range is now extended to coastal streams between Campaña and La Venta. Breder (1927, p. 133) reported it common in the Chucunaque Basin. It has not yet been found on the Canal Zone.

\section{Panamichthys Hubbs.}

The gonopodium is comparatively simple, having no horn-like hooks distally. The tip of this organ is curved abruptly forward to form a sort of hook, which is composed of the closely joined rays 4 and 5 . Only ray 4 has a few serrae on its posterior edge, behind which ray 5 is arched somewhat backward (see Meek and Hildebrand, 1916, p. 323, fig. 8).

\section{Panamichthys panamensis (Meek and Hildebrand).}

Priapichthys panamensis Meek and Hildebrand, Field Mus. Nat. Hist., Zool. Ser., 10, p. 322, fig. 8, 1916-Chame Point, Panama.

This species was made the type of a new genus by Hubbs (1924, p. 8). The characters upon which the genus was based are set forth in the generic account and are shown in the figure accompanying our original description.

Although a specimen was taken in the Rio Chame in 1911, the species was not found in 1937, when another collection was made in that river.

A mistake was made in our original description in giving the position of the dorsal fin. This fin, instead of having its origin "midway between posterior margin of the eye and base of caudal," actually originates midway between the posterior margin of the eye and the end of the caudal.

The species is known only from the type material collected in the Rio Chame, near Chame, and in a brackish pool on Chame Point. 


\section{Poeciliopsis Regan.}

This genus was divided into smaller genera by Hubbs $(1926,63$ and 69 ), who made $P$. elongatus the type of a new genus, Aulophallus, which was based principally upon the structure of the mouth, teeth, and intromittent organ or gonopodium. The mouth was described as transverse, that is, without lateral cleft; the teeth as in a single series, hooked inward, very long, hair-like and loose; and the gonopodium “without the 'crescentic horn' (of some other genera) in membranous tip; none of the segments consolidated; two halves of posterior branch of ray 4 closely united, bearing an apparently single series of thornshaped serrae; segments of anterior branch of ray 5 more oblique, and greatly widened, as though in compensation for lack of specialization of ray 4." I have no special objection to this division of the genus. However, for convenience and brevity, the following accounts are given under the generic name appearing in our earlier publication (1916, pp. 324-326).

Hubbs (1926, p. 69) said, "In agreement with Günther and in disagreement with Steindachner and Meek and Hildebrand, I find but one row of teeth in elongatus; the latter authors have seemingly mistaken some of the fine buccal papillae for teeth." I have removed jaws and teeth from 3 specimens, 1 male and 2 females, in the present collection, and have dried the jaws, to shrink the soft tissues, that the teeth might stand out more prominently. Minute teeth are unmistakably present behind the outer enlarged series in each jaw in the three specimens especially treated and examined. The teeth are similar in shape to the outer ones, but so much smaller that they could be easily overlooked.

\section{Poeciliopsis elongatus (Günther).}

Poecilia elongata Günther, Cat. Fish. Brit. Mus., 6, p. 342, 1866-Panama.

Poeciliopsis elongatus Meek and Hildebrand, Field Mus. Nat. Hist., Zool. Ser., 10, p. 324, fig. 9, 1916.

This species is represented by 81 specimens, ranging from 18 to $140 \mathrm{~mm}$. in length. Many others were taken but not preserved. It is common to numerous in salt and brackish water and ranges to fresh water, which it apparently scarcely enters. The specimens at hand were taken at Farfan Beach in the mouth of a tidal stream, and in the hull of a sunken vessel, which was under water at high tide, but exposed and dry except for small pools within the hull at low tide. Numerous individuals of this species occupied the pools in the hull. It was also taken in small coastal streams between Campaña and La Venta, and many individuals were stranded or occupied the "man 
holes" in the floor of Miraflores Locks, in both the upper and lower chambers of the west side, when dewatered in 1937. As none were seen or taken in Pedro Miguel Locks, it would appear that this fish does not advance so far into fresh water.

The chief recognition marks are the rather long slender body, a moderately depressed head, transverse mouth, and the position of the dorsal and anal fins, which are placed opposite each other, the dorsal, however, beginning a little behind the origin of the anal in the young, as well as in adult females. In adult males the anal fin is greatly modified; it is far in advance of the dorsal and some of the rays are greatly produced, much longer than head, forming of course the intromittent organ, which is not prominently provided with hooks as in most other species of this family. A camera lucida tracing of this organ is shown by Meek and Hildebrand (1916, p. 325, fig. 9); the ventral fins are unmodified in males. Large females often are plain grayish, but smaller specimens, and especially the males, have black crossbars on the posterior part of the body. In the young the bars are fewer, far apart, intensely black, and present anteriorly as well as posteriorly.

The fish appear to be largely herbivorous, judging from the contents of three stomachs examined and by the weak hair-like teeth. The alimentary canal, however, is not long or convoluted as in most herbivorous species. The teeth consist of an outer row of very slender movable teeth curved inward, followed by extremely minute teeth of similar shape. The jaws are very weak.

The young are born at a large size. Examples removed from the ovary of a female, $140 \mathrm{~mm}$. long, had attained a length of $16 \mathrm{~mm}$. They were fully scaled, and already had 4 or 5 black crossbars. The fish undoubtedly are born about this size, as free-swimming specimens only $18 \mathrm{~mm}$. long were taken. In addition to 16 large embryos, the $140 \mathrm{~mm}$. fish contained 35 younger embryos, all already in the "eyed stage," and about $7 \mathrm{~mm}$. long, as well as some large eggs. A smaller female, $90 \mathrm{~mm}$. long, contained five large embryos, and five smaller ones in the "eyed stage"; also some large eggs. The indications are that the broods are born in rapid succession, but that the number in a brood is considerably smaller than in some of the other species of the family, as, for example, in Gambusia affinis of the United States, in which broods of 50 are common, and broods of upward of 100 or even 200 have been found.

This top-minnow reaches a comparatively large size, females $150 \mathrm{~mm}$. long and males $60 \mathrm{~mm}$. long having been taken in Panama. 
This species is apparently confined to the Pacific coast of Costa Rica and western and central Panama. It has not been reported from as far east as the Tuyra Basin.

\section{Poeciliopsis pittieri (Meek).}

Poecilia pittieri Meek, Field Mus. Nat. Hist., Zool. Ser., 10, p. 71, 1912-La Junta, Costa Rica.

Poeciliopsis isthmensis Regan, of which an account was given in our earlier work (1916, p. 325), though not taken by us, was synonymized with $P$. pittieri Meek, by Hubbs (1926, p. 70), who placed the species in his new genus Phallichthys, also carved out of the older genus Poeciliopsis. Behre secured specimens in Costa Rica and also in the Atlantic drainage of extreme western Panama, which were listed by Hubbs (1926, p. 71) and by Behre (1928, p. 316). Breder (1925, p. 141) "questionably referred to this species" a young female taken in a foul drainage ditch below Gatun Spillway. Having collected rather extensively in 1911 and 1912, and again in 1935 and 1937 , in the vicinity of Colon, from whence the types of $P$. isthmensis were reported, I am obliged to conclude that the species either is very rare there, or that a mistake was made in the earlier record. However, the species now unquestionably belongs to the fauna of Panama on the basis of specimens collected in western Panama, to which reference has been made.

Poeciliopsis retropinna (Regan).

Poecilia retropinna Regan, Ann. Mag. Nat. Hist., (8), 2, p. 458, $1908-$ Brocura, Costa Rica.

A ulophallus retropinna Hubbs, Misc. Pub. Mus. Zool., Univ. Michigan, No.16, p. $69,1926$.

Head 4.5 ; depth 3.5 ; D. 9 ; A. 10 ; scales 30 ; snout as long as eye, 3.5 in head; origin of dorsal equidistant from front of eye and end of caudal fin; caudal rounded; origin of anal a little in advance of dorsal; pectorals nearly as long as head. Color olivaceous; scales with dark edges; fins pale (condensed after Regan).

A single specimen, a female $77 \mathrm{~mm}$. long, was known until Hubbs (1926, p. 69) reported it from some tributaries of the Rio Chiriquí del Tire, Pacific slope of western Panama, from specimens collected by Behre, which she also listed (1928, p. 316). Hubbs found the structure of the gonopodium identical with that of elongatus, and placed it in his new genus Aulophallus with elongatus.

This species seems to differ from elongatus, as far as may be judged from the inadequate accounts, principally in the plainer 
color, no crossbars or spots being present. It may be noted here, however, that large females of elongatus, too, are without bars. The habitats seem to differ, as elongatus lives in lowlands and brackish water, whereas retropinna was taken in the mountains of western Panama.

\section{Mollienisia Le Sueur.}

This genus is characterized principally as follows: body moderately robust, compressed posteriorly; mouth small, transverse, with weak teeth in bands in the jaws, the outer ones enlarged and movable; intromittent organ short, preceded by a membranous hood, distally with an antrorse and a retrorse hook; ventral fins modified in males, the first articulated ray being produced. The dorsal fin is sometimes very high in adult males.

Four species were listed in our earlier work (1916, pp. 326-330) under this genus. Two of those listed, namely, formosa from Colón, and cuneata from Turbo, Gulf of Darien, had not been taken by us, and have not been secured by collectors since that time. However, Breder (1927, p. 135) took caucana (made the type of a new genus, Allopoecilia, by Hubbs, 1924, p. 11), in small tributaries of the Rio Sucubtí (Tuyra Basin), Darien, Panama.

Mollienisia sphenops (Cuvier and Valenciennes).

Poecilia sphenops Cuvier and Valenciennes, Hist. Nat. Poiss., 18, p.130, pl. 526, 1846-Vera Cruz, Mexico.

Mollienisia sphenops Meek and Hildebrand, Field Mus. Nat. Hist., Zool. Ser., 10, p. 326, fig. 10, 1916.

Numerous specimens of this common fish were preserved. It was taken on the Pacific slope in swamps at the La Jagua Hunting Club; in the Rio Pacorá and the Rio Cabra; at Fort Kobbe; and in Miraflores Lake and the Rio Cocoli, a short distance above the lake. On the Atlantic side it was taken at Puerto Pilón; Largo Remo Island; Cativa; Fort Sherman (Toro Point); Mount Hope; in several places in Gatun Lake (including Barro Colorado Island); in a small stream on Madden Dam Road; and in Madden Lake, at the mouth of the Boquerón. Next to Astyanax ruberrimus, it is the most numerous fish in the waters of Panama. It ranges from lowland brackish water swamps and streams (being able to endure more salt than $A$. ruberrimus) to upland rivers and creeks, generally occupying quiet, shallow water. Large males, with high dorsal fins with black spots, and generally with blue, greenish, and silvery iridescence are prized as "pet fish" and a limited number are shipped to Europe for use in aquariums. 
The species is adequately described by Meek and Hildebrand $(1916$, p. 326). The chief recognition marks are the depressed head, robust body, and deep, strongly compressed tail. The dorsal and anal fins are opposite each other in the young and adult females, the former beginning a little in advance of the latter, and always marked with dark dots or blotches. In adult males the anal fin moves far forward in the course of development, becoming situated considerably in advance of the dorsal. It is modified to serve as an intromittent organ (gonopodium) for the transfer of the sperms from the male to the female. The members of this genus differ notably from other local forms, except Alfaro, in the structure of this organ, which is covered or preceded distally by a sort of membranous hood. The structure is figured by Meek and Hildebrand (1916, p. 328, fig. 10). The ventral fins, too, are modified in adult males, the first (outer) articulated ray being produced. The dorsal fin in some males, at least, becomes greatly elevated.

As the Atlantic and Pacific slope members of $M$. sphenops cannot be distinguished, it is impossible to determine from specimens if intermingling has taken place through the Canal. However, there is apparently nothing to prevent it. Nevertheless, this fish was not taken in the locks.

The great difference in the size of the males at which the anal fin becomes fully modified, and ready to function as an intromittent organ, is remarkable. For example, a male only $32 \mathrm{~mm}$. long has the organ fully developed, whereas in another male $55 \mathrm{~mm}$. long it is still immature. Although males do not seem to grow quite as large as females, the disparity is not as great as in most groups of this family. Females $100 \mathrm{~mm}$. long, and males upward of $75 \mathrm{~mm}$., have been taken in Panama.

Although this fish generally occupies areas suitable for mosquitobreeding, it probably is not a very effective enemy of the mosquito, as it tends too much to feed on algae.

Attempts have been made to split up sphenops from different areas into species or subspecies. However, insufficient work has been done to demonstrate the divisions, if indeed they exist. As now understood the species may be regarded as ranging from Mexico, on both slopes of Panama to Colombia. Meek and Hildebrand did not take it in the Tuyra Basin, but Breder (1927, p. 134) recorded it from there, having taken it in the headwaters of the Rio Sucubti and its tributaries. 


\section{Mollienisia caucana (Steindachner).}

Girardinus caucana Steindachner, Denkschr. Akad. Wiss., Wien, 42, p. 87, pl. 6, figs. 4, 5, 1880-Cáceres, Colombia.

Mollienisia caucana Meek and Hildebrand, Field Mus. Nat. Hist., Zool. Ser., 10, p. 329, 1916.

This species is known in Panama only from the Tuyra Basin, where we collected it in 1912 in a few of the upper tributaries of the Rio Tuyra, and where Breder later collected specimens in small tributaries of the Rio Chucunaque, which he recorded (1927, p. 135) as Allopoecilia caucana.

Although this species has been made the type of a new genus, Allopoecilia (Hubbs, 1924, p. 11), the writer prefers to leave it with Mollienisia, as the differences in the structure of the gonopodium, upon which the new genus was based, appear too trivial to constitute generic characters. The two species, sphenops and caucana, indeed are closely related, as shown in our earlier work (1916, p. 329).

This species is known from the Tuyra Basin, Pacific slope in eastern Panama, and from the Atlantic slope of Colombia.

Mollienisia cuneata (Garman).

Poecilia cuneata Garman, Mem. Mus. Comp. Zool., 19, p. 62, pl. 5, fig. 3, 1895-Turbo, Gulf of Darien.

Mollienisia cuneata Meek and Hildebrand, Field Mus. Nat. Hist., Zool. Ser., 10, p. 329, 1916.

This species, regarded by Hubbs $(1926, p .77)$ as a subspecies of $M$. sphenops, was included in our earlier work on the basis of its description from Turbo, Gulf of Darien. It has not been taken in Panama by recent collectors. Hubbs (loc. cit.) considers Colombian material as belonging to cuneata.

Mollienisia formosa (Girard).

Limia formosa Girard, Proc. Acad. Nat. Sci. Phila., p. 115, 1859-Palo Alto, Mexico.

Mollienisia formosa Meek and Hildebrand, Field Mus. Nat. Hist., Zool. Ser., 10, p. 330, 1916.

This species was included in our earlier work on the basis of a record by Regan (1913, p. 1012), who listed it from Colón. It has not been taken in Panama by recent collectors.

Hubbs and Hubbs (1932, pp. 628-630) have claimed that $M$. formosa is a hybrid, resulting from a cross between sphenops and latipinna. If that be true, formosa could not occur in Panama, as latipinna does not range southward to the Isthmus of Panama. 
The habitat of $M$. formosa generally has been given as the Atlantic slope of Mexico and Central America.

Alfaro Meek.

This genus differs from all other genera of this family known from Panama in the presence of a sharp keel along the lower edge of the caudal peduncle, the keel being formed by a double series of paired scales. The intromittent organ is somewhat similar to that of Mollienisia, being short and preceded or covered anteriorly by a membranous hood. Unlike Mollienisia, however, it is without hooks or retrorse spines.

This genus is not included in our earlier work. It is added here on the basis of specimens collected on the Atlantic slope of extreme western Panama, as shown subsequently.

\section{Alfaro cultratus (Regan).}

Petalosa cultratum Regan, Ann. Mag. Nat. Hist., (8), 2, p. 458, 1908-Rio Iroquois, Costa Rica.

This species belongs to the fauna of Panama on the basis of specimens collected on the Atlantic slope of extreme western Panama by Dr. E. H. Behre. These specimens were recorded by Hubbs (1926, p. 79) and by Behre (1928, p. 317).

Head 3.8 to 4.3 ; depth 3.1 to 3.7 ; D. 7 or 8 ; A. 9 or 10 ; scales 32 to 34 . Body much compressed, profile from nape to dorsal straight; head flat above; snout 2.7 to 3.2 in head; eye 2.7 to 3.1 ; dorsal fin on posterior third of body; pectorals broad, 1.2 to 1.4 in head. Color olivaceous, no spots or bars; vertical fins slightly dusky (condensed after Meek's description of $A$. acutiventralis, a synonym of cultratus).

This species differs from all other species of the family known from Panama, in the sharp keel along the lower edge of the caudal peduncle, formed by double series of paired scales, which is a character considered of generic importance.

\section{Family CYPRINODONTIDAE}

Body elongate, compressed, at least posteriorly; mouth small, terminal; premaxillaries protractile; teeth pointed or more or less incisor-like; gill membranes united, free from the isthmus; gill rakers short and thick; scales moderately large, cycloid; no lateral line; dorsal fin single, with soft rays only; caudal square to more or less pointed, not forked; anal somewhat similar to dorsal, not modified in male; ventrals abdominal, species oviparous. 


\section{Field Museum of Natural History-Zoology, Vol. XXII}

A single genus is known from Panama, namely, Rivulus, which was included in the family Poeciliidae in our earlier work. The oviparous species now are separated from the viviporous ones under the family name appearing herewith by nearly all ichthylogists.

\section{Rivulus Poey.}

The fishes of this genus are slender, generally depressed anteriorly, but always compressed posteriorly. The head is low and flat above; the mouth is small and forms a vertical groove in front of the very narrow preorbital; the teeth are villiform, generally present on the vomer and always in bands in each jaw, the outer ones generally being somewhat enlarged. The fins are rounded; the caudal is square to pointed, and occasionally more or less notched at the end of the upper or lower rays in males. The dorsal is small and is inserted far back over the posterior part of the much longer anal. The coloration generally is rather plain, the females often having an ocellus at the base of the upper caudal rays.

The species are very slimy when removed from the water. They are difficult to seine, as they seem to escape by clinging close to the bottom, or by finding protection under or among objects in the water. Many more fish were seen in pools in a creek on Barro Colorado Island, Canal Zone, for example, than were captured by repeated seining.

Only two species of this genus were included in our earlier work. The number of species found has increased to five, two of which apparently require names. Because of the additions made, a key to the species is introduced.

\section{KEY TO SPECIES OF RIVULUS}

a. Caudal fin broadly rounded to nearly square.

$b$. Scales rather large, 33 to 40 in lateral series between upper angle of gill opening and base of caudal, 7 or 8 complete longitudinal rows between bases of dorsal and anal.

c. Body moderately robust, depth 4.5 to 5.2 , and depth of caudal peduncle 7 to 7.75 in standard length in adults; scales 33 to 37 ; general color

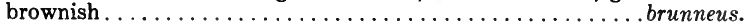

cc. Body slender, depth 5.5 to 6 , and depth of caudal peduncle 8.2 to 9 in standard length; scales 38 to 40 ; general color bluish.... chucunaque.

$b b$. Scales smaller, 42 to 45 in lateral series between upper angle of gill opening and base of caudal, 10 or 11 complete rows between bases of dorsal and anal.

d. Head only moderately depressed, not much broader than deep, its greatest width 1.4 to 1.5 in its length; interorbital 3.3 to 3.9 in head; pectorals rather long, reaching about three-fourths to ventrals; color brownish, with pale markings; vertical fins with black spots.

volcanus, sp. nov. 
dd. Head strongly depressed, notably broader than deep, its greatest width 1.3 in its length; interorbital 2.9 in head; pectorals short, reaching only halfway to ventrals; color plain, scales slightly dark-edged; vertical fins plain or with light spots....... hildebrandi.

aa. Caudal fin moderately pointed; body slender, depth 5 to 6 , and depth of peduncle 7.6 to 8.6 in standard length; scales 33 to 38 in lateral series, between upper angle of gill opening and base of dorsal, 8 or 9 complete longitudinal series between bases of dorsal and anal ... montium, sp. nov.

Rivulus brunneus Meek and Hildebrand.

Rivulus brunneus Meek and Hildebrand, Field Mus. Nat. Hist., Zool. Ser., 10, p. 86, 1913-Toro Point, Canal Zone; ibid., p. 331, 1916.

Six specimens, ranging in length from 18 to $50 \mathrm{~mm}$., were collected in pools left in a creek near the end of the dry season, on Barro Colorado Island.

The following measurements and counts are based on four specimens taken on Barro Colorado Island, and on four paratypes. Head

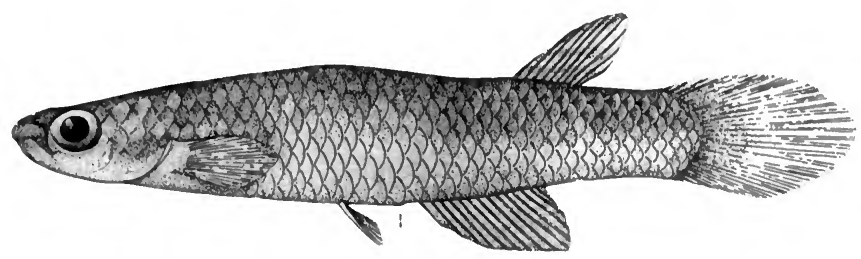

FIg. 7. Rivulus brunneus Meek and Hildebrand. Male specimen, $50 \mathrm{~mm}$. long. (From drawing by Andrew Pizzini.)

3.4 to 4.1 ; depth 4.5 to 5.2 ; D. 9 or 10 ; A. 12 to 14 ; scales 33 to 37 , complete rows between bases of dorsal and anal 7 or 8 . Eye 3.5 to 3.75 in head; interorbital 2.8 to 3.2 ; caudal peduncle 1.9 to 2.2 in head, or 7 to 7.75 in standard length; pectoral 1.5 to 1.7 in head. Ventrals fully as long as eye, reaching vent.

This species is known only from the Atlantic slope of the Canal Zone, where it inhabits small creeks.

\section{Rivulus chucunaque Breder.}

Rivulus chucunaque Breder, Amer. Mus. Nat. Hist., Nov., No. 180, p. 7, fig. 6,1925-Rio Chucunaque Basin, Darien, Panama; Bull. Amer. Mus. Nat. Hist., 57, p. 135, fig. 8, 1927.

This species was described from specimens taken in a small side stream of the Rio Chucunaque, Darien, by Breder. I have made a direct comparison of paratypes of this species and paratypes of brunneus. These species are closely related, as suggested by Breder, 
who stated that the chief difference seemed to be that of color, brunneus being brownish with black dots, which are faint on the dorsal and caudal fins, whereas chucunaque is pale bluish, sprinkled with pink dots forming more or less distinct lines along the rows of scales, having no caudal ocellus, the dorsal and caudal being profusely marked with dark spots.

Upon comparison of specimens of equal size it is evident that chucunaque is a more slender fish. Proportional measurements overlap partly because small specimens (juveniles) are more slender than large ones. In four paratypes of chucunaque ranging in length from 38 to $45 \mathrm{~mm}$., the depth is contained in the standard length 5.5 to 6 times, and the caudal peduncle 8.2 to 9 times, whereas in five specimens of brunneus, ranging in length from 40 to $50 \mathrm{~mm}$., the same proportions are, respectively, 4.5 to 5.2 , and 7 to 7.75 .

The average number of oblique rows of scales between the upper anterior angle of the gill opening and the base of the caudal seems to be somewhat greater in chucunaque. The number in four paratypes counted ranges from 38 to 40 , whereas in eight specimens (including four paratypes) of brunneus the range is from 33 to 37 .

Mr. Breder recognized a subspecies of chucunaque, naming it sucubti, the type material having been taken in a small side stream of the Rio Sucubtí, Darien. This subspecies is slightly more robust than the typical subspecies, according to Mr. Breder, though that is not evident from the particular paratypes examined, the ventral and vertical fins tend to be longer, and the dark spots on the dorsal, caudal, and anal fewer and larger. In general, this subspecies seems to be rather closer to brunneus than the typical subspecies.

$R$. chucunaque, including both subspecies, is known only from the type material from the Chucunaque Basin, Darien, Panama.

\section{Rivulus volcanus sp. nov.}

Ritulus isthmensis Hildebrand (not Garman), Copeia, No. 168, p. 84, 1928

Lagunas Verde, Grande, and Gulnar, Chiriquí, Panama.

Type from Laguna Grande (or Davis), Chiriquí, Panama. No. 106509 United States National Museum. Male. Length $44 \mathrm{~mm}$.

Description of the type.-Head 3.7; depth 5.8; D. 9; A. 14; scales (oblique series between upper angle of gill opening and base of caudal) 45, complete longitudinal rows between bases of dorsal and anal 11.

Body slender, scarcely depressed anteriorly, compressed posteriorly; caudal peduncle strongly compressed, 8.1 in standard length, 
2.2 in head; head moderately depressed, somewhat broader than deep, its greatest width 1.5 in its length; snout moderately short, 4.3 in head; eye wholly lateral, 3.6 ; interorbital (bone) about equal to diameter of eye; scales small, rather difficult to enumerate, enlarged on head, reduced on chest, extending somewhat on base of caudal; dorsal small, the rays reaching first rudimentary ray of caudal, its origin about over beginning of last third of anal; caudal broadly and evenly rounded, about as long as head; anal rather long, ending nearly under middle of base of dorsal; ventrals small, scarcely as long as eye, failing to reach vent; pectorals broadly rounded like the caudal, reaching nearly three-fourths the distance to the ventrals, 1.6 in head.

Color of preserved specimen brownish above, pale below; the brownish color broken somewhat by irregular pale markings; dorsal, caudal, and anal all marked with dark spots, the ones on margin of

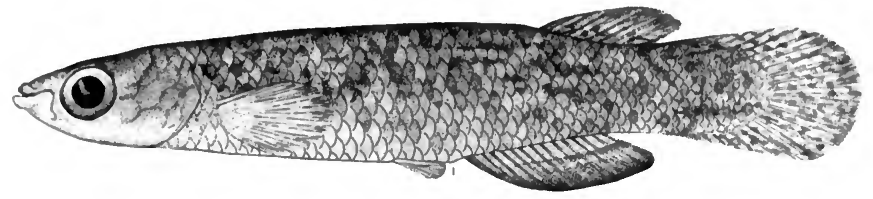

FIG. 8. Rivulus volcanus sp. nov. Type, male, $44 \mathrm{~mm}$. long. (From drawing by Andrew Pizzini.)

anal tending to coalesce, forming a dark border; ventrals and pectorals plain.

Variations within the species, as shown by the paratypes, are as follows (measurements and counts are based on nine specimens, unless otherwise stated, ranging in length from 35 to $44 \mathrm{~mm}$.): Head 3.7 to 4.1 ; depth 5 to 5.8 ; D. 9 or 10 ; A. 13 to 15 (13 in 3,14 in 10 , and 15 in 4 specimens); scales (oblique series between upper angle of gill opening and base of caudal) 42 to 45 , complete longitudinal series between bases of dorsal and anal 10 or 11 . Snout 4.3 to 5.2 in head; eye 3.3 to 3.7 interorbital (bone) 3.3 to 3.9 ; width of head 1.4 to 1.5 ; caudal peduncle 2.2 to 2.6 ; pectoral 1.5 to 1.6 .

The females, which are greatly in the majority in the collection, in general appear to be a little more robust than the males and the vertical fins are a little lower. They are a little lighter in color, have a definite ocellus on the upper part of the base of the caudal, and some of them have the anal definitely margined with 
black. The spotting on the vertical fins is the same as in males, except that in a few females the black dots form indefinite and irregular bars. A fresh specimen is described in my field notes as grayish green above, and pale to orange below.

This species differs from hildebrandi, recorded from the same general vicinity, namely, Boquete, Panama, in being less robust, in having a narrower and less depressed head, longer snout, narrower interorbital, longer pectoral, and being less plain in coloration.

The specimens were compared, also, with specimens in the National Museum identified as isthmensis, taken at San José (the type locality of isthmensis), Miravalles, and Ochomago, Costa Rica. The Panama specimens are near relatives of this Costa Rican species, but the former differ in (a) the more slender body, (b) narrower head, (c) more numerous scales, and $(d)$ in having the body light-spotted instead of dark-spotted. Most of the Costa Rican specimens have enlarged black spots on the sides posterior to the pectorals. Though the vertical fins are dark-spotted in both species, the spotting is finer and more profuse in the Panama specimens. The following proportions are based on 8 and the counts on 12 specimens of isthmensis: Head 3.6 to 4.1 ; depth 4.1 to 4.8; D. 8 or 9 ; A. about evenly 13 or 14 ; scales 35 to 39 , longitudinal rows between dorsal and anal 8 or 9 . Snout 4.5 to 5.3 in head; eye 3.6 to 4.2 ; interorbital (bone) 2.6 to 3 ; caudal peduncle 2 to 2.1 ; pectoral 1.5 to 1.75 .

The present collection contains 40 specimens, ranging in length from 12 to $44 \mathrm{~mm}$., consisting of 3 males, 33 females, and 4 juveniles. A few of these specimens were seined in Laguna Gulnar, the rest in a shallow weedy cove of Laguna Grande, where the species was common. These lakes are at an elevation of about 4,500 feet, and supposedly occupy extinct volcanic craters. In addition, the specimens (not in good condition now), reported upon by me as isthmensis (1928, p. 84) from Chiriquí, were re-examined. This lot contains a specimen $76 \mathrm{~mm}$. long, therefore much larger than any secured recently.

The species is named volcanus after the volcanic lakes in which it lives. The name, Volcán, also is applied to the general vicinity in which the lakes occur.

\section{Rivulus hildebrandi Myers.}

Rivulus hildebrandi Myers, Ann. Mag. Nat. Hist., (9), 19, p. 123, 1927Boquete, Chiriquí, Panama.

This species differs from other species from Panama according to the examination and direct comparison of a paratype, a male 
$60 \mathrm{~mm}$. long (U.S.N.M. No. 92958), in (a) the robust body, which is depressed anteriorly; $(b)$ the very short, broad head; $(c)$ the very short, blunt snout; $(d)$ the broad interorbital; $(e)$ the short pectoral, which reaches only half the distance to the base of the ventral; and $(f)$ the rather plain coloration, the scales being slightly dark edged, the dorsal, caudal, and anal being faintly light-spotted, the last having a dark margin. The original description states that the fins in females are plain, and have a small ocellus on the upper part of the base of the caudal.

The following proportions and counts are based on the paratype examined: Head 4.25 in standard length, depth 4.75 ; caudal peduncle 7.25 ; predorsal length 1.35 ; pectoral 6.5 ; D. 9 ; A. 12 ; scales in 42 oblique series between upper anterior angle of gill opening and base of caudal, and 11 complete longitudinal rows between the bases of the dorsal and anal. The scale counts in lateral series are given as 49 to 50 in the original description. The difference may result from the place the counts are made. Myers may have counted from the occiput, whereas I counted from the upper angle of the gill opening. Snout about 4.6 in head; eye 3.3; interorbital (bone) 2.9 ; width of head 1.3; caudal peduncle 1.8; pectoral 1.55. Ventrals a little shorter than diameter of eye, reaching only half the distance to vent; origin of dorsal slightly posterior to middle of base of anal.

This species is known only from the type specimens from Boquete, Chiriquí, Panama.

\section{Rivulus montium sp. nov.}

Rivulus elegans Meek and Hildebrand (not Steindachner), Field Mus. Nat. Hist., Zool. Ser., 10, p. 331, 1916.

Type from a hillside trickle between Rio Boquerón and Rio Pequeni, (Chagres Basin), Panama. No. 34880 Museum of Comparative Zoology. Total length $63 \mathrm{~mm}$., standard length $50 \mathrm{~mm}$.

Description of the type.-Head 3.8; depth 5.25 ; D. 9; A. 12; scales (oblique series between upper angle of gill opening and base of caudal) 38, complete longitudinal rows between bases of dorsal and anal 9.

Body about as broad as high anteriorly, strongly compressed posteriorly; depth of caudal peduncle 8 in standard length, 2.1 in head; head depressed, notably broader than deep, its greatest width 1.55 , and its depth 1.9 in its length; snout broader than long, its length 4.3 in head; eye lateral, 4.35 , interorbital 3.25 ; scales in regular series, enlarged on head, somewhat reduced on chest, and extending on basal third of caudal; dorsal rather high, the rays 
graduated, next to the last one longest, reaching nearly to rudimentary rays of caudal, its origin over middle of base of anal; caudal fin long, not notched, moderately pointed, the middle rays longest, about as long as head; anal rather high posteriorly, the longest rays equal to those of dorsal, and as long as postorbital part of head, its base ending slightly in advance of end of base of dorsal; ventrals scarcely longer than eye, reaching almost to vent; pectorals with rounded margins, reaching only slightly more than half the distance to base of ventrals, 1.75 in head.

Color grayish brown above, pale gray underneath; posterior half of sides with inconspicuous dusky spots. The vertical fins somewhat darker than the upper parts of the body; dorsal and anal with dark spots which are inconspicuously present on the base of the caudal also. Ventrals pale, with dusky outer margins; pectorals slightly dusky, especially distally.

The variation within the species, as shown by the type and six paratypes ranging in length from 32 to $53 \mathrm{~mm}$., is as follows: Head 3.7 to 4.1 ; depth 5 to 6 ; D. 8 or 9 ; A. 12 or 13 ; scales 33 to 38 , complete longitudinal rows between bases of dorsal and anal 8 or 9 . Snout 4 to 5.2 in head; eye 3.75 to 4.6 ; interorbital 2.8 to 3.4 ; width of head 1.4 to 1.6 ; depth of head 1.7 to 2.3 ; caudal peduncle 1.9 to 2.2 in head, or 7.6 to 8.6 in standard length; pectoral 1.4 to 1.7 in head.

The single adult female at hand, $44 \mathrm{~mm}$. long, has a dark ocellus at the base of the upper rays of the caudal. It is rather lighter in color than the adult males, and in contrast with the males it has dark markings on the anterior part of the body, which tend to form lines along the rows of scales; posteriorly, contrary to the males, dark spots are missing, except for a few at the base of the caudal. The dorsal bears black spots as in the male, but the caudal is plain dusky, and the anal is very pale at the base, becoming dusky along the margin. The ventrals are pale, and the pectorals are only slightly dusky. Immature fish are all more or less speckled with dark specks; lower part of caudal with or without a black longitudinal stripe, forming an intramarginal band.

The dorsal and anal fins are not quite as high in the adult female as in large males, though similar in shape, and the caudal fin is about equally pointed.

The immature specimens, 26 to $38 \mathrm{~mm}$. long, from a small stream on the Atlantic slope near the summit of the ridge, at Culebra, 
Canal Zone, collected in 1911, and listed as $R$. elegans by us (1916, p. 331) were re-examined, and appear to belong to the present species.

This species differs from $R$. elegans, following the original description and figure (Steindachner, 1880; p. 33, fig. 6) (a) in the pointed caudal fin, which is shown as somewhat concave in Steindachner's figure of elegans, though described as broadly rounded to square; (b) in the apparently fewer anal rays, that is, 11 or 12 in the present species, and 13 to 15 in elegans; $(c)$ in the fewer scales on the base of the caudal, present only on the basal third of the fin, whereas in elegans they cover the basal half; $(d)$ the pectoral fins are shorter as they reach within half an eye's diameter of the base of the ventrals in elegans, whereas the space between these fins in the adults of the present species exceeds the full diameter of the eye; and $(e)$ in color, the species differing principally in the color of the spots on the body, which are dark or black in the present species, whereas they are

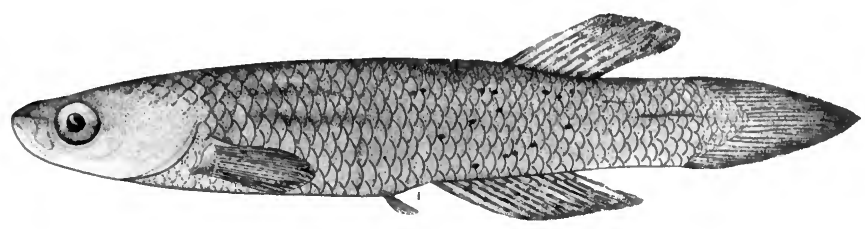

Fig. 9. Rivulus montium sp. nov. Type, male, $66 \mathrm{~mm}$. long. (From drawing by Andrew Pizzini.)

indicated in Steindachner's figure as pale, and most distinct on the third and fourth row of scales below the base of the dorsal. The anal fin in males is distinctly spotted with black in the present species. No spots are shown on this fin in Steindachner's figure, which is presumably based on a male, as no caudal ocellus is shown.

This species apparently lives in small mountain streams, and to date is known only from the Chagres Basin from the type and six paratypes taken in a mountain trickle on the ridge between the Rio Pequeni and the Rio Boquerón (upper tributaries of the Chagres) by J. A. Griswold, and from 22 immature specimens taken in very small streams on the Atlantic slope near the summit at Culebra by us in 1911. The specimens taken by Mr. Griswold were sent to the Museum of Comparative Zoology for identification, and were lent for study through the kindness of W. C. Schroeder, curator of fishes in that museum. The type has been deposited in the Museum of Comparative Zoology, as already shown, but some of the paratypes 
will be retained, with the permission of Mr. Schroeder, for the National Museum.

As this species has been taken only in the mountains it is here named montium.

\section{Family MUGILIDAE. Mullets; Liza; Dajao}

Agonostomus Bennett.

The fresh-water mullets of this genus are known quite generally as "dajao" in Central America and the West Indies. They resemble the marine mullets in many respects, but differ in having a normal stomach, not gizzard-like as in the marine forms. The walls in Agonostomus, nevertheless, are rather thick. The mouth is larger, with heavier lips, the cleft extending laterally to or beyond the front of the eye, and the lower jaw is rounded (not angulate) anteriorly. The anal fin has only two spines that are free distally. However, a third, undivided ray is attached to the first divided or articulated ray. The young of the marine mullets have the third ray similarly constructed shortly before it becomes a definite spine with a sharp point. In Agonostomus the third ray apparently never becomes a definite spine. The anal formulae, as generally written, therefore, show only two spines, the third ray being included with the ones divided.

Two species which may prove to intergrade, namely, monticola and macracanthus, are recorded from Panama. A. macracanthus is apparently rare and differs from the more common one only in having a somewhat deeper body and a larger mouth.

Agonostomus monticola (Bancroft).

Mugil monticola Bancroft, in Griffith's Edition of Cuvier's Animal Kingdom, Fishes, p. 367, pl. 36, 1836-West Indies.

Agonostomus monticola Meek and Hildebrand, Field Mus. Nat. Hist., Zool. Ser., 10, p. 334, 1916.

This species was taken in 1935 and 1937 at Fort Sherman (Toro Point), and in the Rio Cocoli, a tributary of Mirafiores Lake, Canal Zone. It is evident, therefore, that the species occurs in both the Atlantic and Pacific drainages, which it also did before the opening of the Canal. As the species is apparently confined to rocky streams it probably seldom if ever enters the Canal.

Dajao unmistakably were seen, but not captured, also in the Rio Capira at Campaña, and in the Rio Chiriquí Viejo, at an elevation of about 4,600 feet. The Rio Chiriquí Viejo, being rather far 
removed (in western Panama) from the other points where we collected, it seemed especially desirable to obtain samples there for comparison with the ones from central Panama, but all efforts failed. Behre (1928, p. 312), whose specimens I have not seen, recorded this species from both slopes of western Panama without comment, indicating that she considered her specimens true monticola. During the earlier investigations (1911 and 1912) this species was taken in the Chagres Basin, in small streams at Porto Bello, and Toro Point, and on the Pacific side in almost every stream sampled in central Panama.

Dajao commonly inhabit rocky streams where seining is difficult, and they are as elusive as their salt-water relatives. They rarely take a hook. The species are valued as food, and reach a length of about $300 \mathrm{~mm}$.

This fish occurs from sea level to mountain streams. According to the contents of stomachs of specimens taken in Puerto Rico it feeds on rather small organisms, such as insects, insect larvae, sponges, and apparently on algae. A specimen taken at Toro Point had ingested a small grasshopper.

This species is characterized by the rather slender, somewhat compressed body, which varies considerably in depth, being contained 3.2 to 4.1 in standard length; head 3 to 4.1 ; D. IV-I, 8 ; A. II (or III) 8 to 10 ; scales 38 to 43 . The mouth is rather small, the maxillary reaching only to or a little beyond the anterior margin of the eye, 2.6 to 3.2 in head; eye 3.3 to 4.9 ; snout 3.1 to 4.3 . The color is bluish black above, pale below, and in life yellowish along the sides, the brightness varying according to place of capture, those living in clear upland streams generally being more highly colored. The young sometimes have a dark lateral band, at least posteriorly, and a dark caudal spot seems to be present at all ages.

This species is recorded from Mexico, Central America, and the West Indies. Although it is common on both slopes of central Panama it has not been reported from eastern Panama, nor from Colombia.

\section{Agonostomus macracanthus Regan.}

Agonostomus macracanthus Regan, Ann.Mag. Nat. Hist., (7), 19, p. 65, 1907

-Rio Guacalate, Guatemala; Meek and Hildebrand, Field Mus. Nat.

Hist., Zool. Ser., 10, p. 335, 1916.

No specimens of this apparently rare species were secured in 1935 and 1937. We reported in our earlier work only two specimens, which were taken in the Rio Indio, an upper tributary of the Chagres. 
Behre (1928, p. 312) recorded four specimens from the Atlantic slope of extreme western Panama. It is not reported from eastern Panama, though Eigenmann (1922, p. 187) recorded two specimens from San Lorenzo, Colombia.

Its range, according to the literature at hand, extends from the Rio Guacalate (Pacific), Guatemala to San Lorenzo (Atlantic), Colombia.

\section{Joturus pichardi Poey.}

Joturus pichardi Poey, Memorias, 2, p. 263, 1860-Cascades throughout Cuba; Meek and Hildebrand, Field Mus. Nat. Hist., Zool. Ser., 10, p. 336, 1916.

This fish is known from Panama only from the Chagres Basin. It lives at the base of waterfalls. It was not taken in 1935 nor 1937. The specimens reported by us $(1916, \mathrm{p} .336)$ were caught at the foot of waterfalls on the Rio Indio, an upper tributary of the Chagres, and at the base of the Gatun "Spillway," an artificial falls.

This species is known from Cuba, and from Mexico to Panama.

\section{Family CICHLIDAE. Mojarras}

Five genera were included in our earlier (1916) work. One genus, Herotilapia (with one species) is now added on the basis of a record by Behre (1928) from western Panama. This genus is readily recognized by the compressed, incisor-like, tricuspid teeth. Its nearest relative in central Panama is Neetroplus, which has simple incisors in the jaws; that is, compressed teeth with even cutting edges.

Six species of the genus Cichlasoma were added to the fauna of Panama by Dr. Behre, in the paper already referred to, since the publication of our earlier work. Dr. Behre collected in extreme western Panama, which appears to be inhabited chiefly by Central American species. The specimens collected by Dr. Behre were not seen by me.

The common name for this family usually appearing in books is "mojarras." However, ichthyologists use the name "cichlids," derived from the generic name Cichlasoma. This term appears several times in the following pages.

Aequidens coeruleopunctatus (Kner and Steindachner). "Chogorro."

Acara coeruleopunctata Kner and Steindachner, Sitzber. Akad. Wiss., München, p. 222, 1863-Rio Chagres, Isthmus of Panama.

Aequidens coeruleopunctata Meek and Hildebrand, Field Mus. Nat. Hist., Zool. Ser., 10, p. 339, 1916. 
This is one of the most generally distributed species in the waters of central and eastern Panama. Specimens were taken on the Atlantic side, in 1935 and 1937, in a creek below an abandoned reservoir at Gatun; in Gatun Lake at Gatun, Barro Colorado Island, and several places between Gamboa and Madden Dam; and in a creek tributary to Gatun Lake on Madden Dam Road. On the Pacific side it was secured in coastal streams between Campaña and La Venta, Rio Capira at Campaña, Rio Pacorá on the Chepo Road, La Jagua Hunting Club, Miraflores Lake, and in the Rio Cocoli. It was not present in the locks at either end of the Canal when they were dewatered in 1935 and 1937.

This species does not grow large enough to have much value as a food fish. The largest specimen at hand is only $145 \mathrm{~mm}$. long, though one of $157 \mathrm{~mm}$. has been reported. The average size is only about $100 \mathrm{~mm}$. It is not as numerous in Gatun and Miraflores lakes as Cichlasoma maculicauda.

Breder (1927, p. 139) has reported that this fish, according to stomachs examined by him, feeds largely on insects, though a large amount of debris, including some plant tissue, was present. The three stomachs examined by me all contained fragments of insects. One contained a mass of crushed molluscan shells; two contained a few ostracods; and one definitely contained fragments of a plant. The pharyngeal teeth are well developed, in two large patches above and one below, and the individual teeth are rather blunt. The presence of this grinding apparatus, together with the fragmentary appearance of the foods ingested, suggests that a fair degree of mastication precedes swallowing.

This cichlid is easy to recognize in life, among its relatives in Panama, by the emerald green spots on the head and sides, and by two lines of the same color on the cheeks. These spots and lines generally remain visible in preserved specimens but become dusky. A more or less definite dark lateral band is generally present, with an intensely black blotch below the spinous dorsal, and frequently with a second but smaller black spot at the base of the caudal. The young lack the emerald green spots and lines mentioned, and are distinctly barred with black. These black bars often persist in adults and form saddle-like blotches on the back. The gill arches are normally formed, and the gill rakers are short and fleshy, more or less fan-shaped, and only seven or eight are more or less developed on the lower limb of the first arch. In adults the head is broad, and the interorbital greatly exceeds the diameter of the eye. The anal 
fin consists of only 3 spines and 7 or 8 soft rays, and the dorsal has 14 or 15 spines and 9 to 11 soft rays. The scales are large, as there are only 26 or 27 in a lateral series and only 3 between the lateral line and the origin of the dorsal. The body is not as deep as in some of the other cichlids, as the depth is contained 2 to 2.3 times in the standard length.

Two of three specimens dissected were females with large roe. One of these was taken February 11 and the other April 2. The third specimen, a male, caught February 23, was undeveloped. Many young, ranging upward of $10 \mathrm{~mm}$., apparently belonging to this species, were collected during February. The indications, therefore, are that spawning takes place during the dry season.

The range extends from central (both slopes) to eastern Panama and somewhat doubtfully into Colombia and northwestern Ecuador. In Colombia it seems to be replaced chiefly by $A$. latifrons, which from a study of descriptions (no specimens being available) seems doubtfully distinct. A. coeruleopunctatus has not been recorded from western Panama.

\section{Geophagus crassilabris Steindachner.}

Geophagus crassilabris Steindachner, Sitzber. Akad. Wiss., Wien, 74, p. 65, pl. 7, 1876-vicinity of Candelaria, Isthmus of Panama; Meek and Hildebrand, Field Mus. Nat. Hist., Zool. Ser., 10, p. 340, 1916.

This cichlid is rather common in the streams of both slopes of central Panama, and also in the Tuyra Basin, as shown by collections made by us in 1911 and 1912 and by Breder (1927, p. 139). In 1935 and 1937 it was taken only in Gatun Lake near Madden Dam, in a creek tributary to Gatun Lake on the Madden Dam Road, and in Miraflores Lake. This species is known to reach a length of at least $265 \mathrm{~mm}$. Although it was taken in both Gatun and Miraflores lakes, it does not seem to be common, and probably cannot be considered available as a food and game fish.

This species is readily recognized by its long, pointed snout, which is much longer than the postorbital part of the head in adults, and proportionately much longer than in any other cichlid known from Panama. It differs from all other Panama species, furthermore, in the peculiar development of the upper part of the gill arch, which is provided with a fleshy growth, usually described as a lamelliform lobe. Adult males have a very prominent nuchal hump. This species has only 3 anal spines and 7 or 8 soft rays. Its dorsal fin consists of 16 spines and 9 or 10 soft rays. Most specimens have more or less definite crossbars, and the young also have a black 
lateral band. A fresh specimen, about $175 \mathrm{~mm}$. long, had the color as follows: Greenish above, slightly golden on the belly, with indications of dark broken crossbars on the sides, and a large black blotch on the side below the posterior part of the spinous dorsal. The large lips were dark blue, and the opercle bluish green to black. Individual scales on the side were bluish green. The pectorals were greenish, and all the other fins were pink to reddish.

The range seems to be limited to both slopes of central and eastern Panama. It has not been taken in western Panama. In Colombia it seems to be replaced by the closely related $G$. pellegrini.

Cichlasoma Swainson.

All the cichlids known to occur in Panama having conical, or somewhat compressed teeth, yet surmounted by conical apices (not incisor-like teeth), in combination with 5 or more anal spines, are herein included in the genus Cichlasoma. It seems advisable to present a key, because six species not included in our earlier publication (1916) have been added by the work of Behre (1928). Unfortunately, it has not been possible to examine Dr. Behre's collection, and no other specimens have been available to me for examination of altifrons or lethrinus. Therefore, it has been necessary to rely partly on published accounts for some of the characters used in the key.

\section{KEY TO SPECIES OF CICHLASOMA}

a. Teeth all conical or pointed, not notably or at all compressed; fold of lower lip continuous or interrupted.

$b$. Snout long, much longer than postorbital part of head; D. XVI, 11; A. V, 8 or 9 ; about 30 scales in lateral series; body with 5 or 6 dark crossbars; no lateral band ....................................

$b b$. Snout shorter, little if any longer than postorbital part of head; dorsal usually with 17 or 18 spines; anal with 6 to 10 spines.

c. Lower lip broad, with a continuous free fold; body moderately to quite elongate, the depth about 2.2 to 3 in standard length.

$d$. Body quite elongate and robust, the depth about 2.5 to 3 in standard length; lower jaw projecting; anterior pair of teeth in upper jaw notably enlarged, canine-like; sides with a series of dark spots forming a more or less continuous lateral band; definite dark hars present only in young; D. XVII or XVIII, 10 or 12 ; A. VII, 8 to 10; scales 30 to 32,5 or 6 rows between lateral line and origin of dorsal, but only 3 between lateral line and middle of base of dorsal.

motaguense.

$d d$. Body rather deeper and more strongly compressed, the depth about 2.15 to 2.5 in standard length; lower jaw not reaching beyond the upper one; none of the teeth greatly enlarged or canine-like.

$e$. Snout long and rather pointed, equal to or somewhat longer than postorbital part of head; lateral line rather strongly arched, only 3 or 4 complete rows of scales between it and origin as well as middle of dorsal; sides with a large black blotch under middle of 
base of dorsal, a smaller one on upper half of base of caudal; distinct crossbars and a lateral band present only in young.

calobrense.

$e e$. Snout shorter, less pointed, a little shorter than postorbital part of head; lateral line less strongly arched, with 5 or 6 complete rows of scales between it and the origin as well as middle of dorsal; sides with a rather narrow, well-defined, continuous black lateral band; no crossbars except in very young.......... umbriferum.

cc. Lower lip narrower, the fold not continuous, being interrupted anteriorly; body deep to only moderately elongate.

f. Body very deep, the depth 1.75 to 2 in standard length.

g. Scales rather small, 34 to $\mathbf{4 0}$ in lateral series; lateral line at point of interruption reappearing on fifth row of scales below its original course; adults with a series of about six dark blotches along middle of side; young with dark crossbars; scales with dark dots, forming more or less definite rows..............tuyrense.

gg. Scales larger, 28 to 33 in lateral series; lateral line at point of interruption reappearing on third row of scales below its original course.

$h$. Scales large, 28 to 30 in lateral series, 2 or 3 complete rows between lateral line and middle of base of dorsal; D. XVIII or XIX, 9 or $10 ; \mathrm{A}$. VIII or IX, 7 or 8 ; sides with about 7 crossbars; no lateral band . . . . . . . . . . . . . . . . . . spilurum.

$h$. Scales somewhat smaller, 31 to 33 in a lateral series, 5 or 6 complete rows between lateral line and middle of dorsal; D. XVII or XVIII, 11 or 12 ; A. VI, 9 or 10 ; no distinct bars and no lateral band, except in very young; a large black blotch at base of

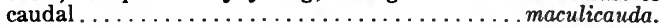

ff. Body moderately elongate, the depth about 2.3 to 2.6 in standard length.

$i$. Scales large, 29 to 31 in lateral series; D. XVII or XVIII, 10 to 12 ; pectoral nearly as long as head, reaching to first or second anal spine; sides with 6 dark crossbars, and a more or less continuous dark lateral band; sides of head not spotted......... lethrinus.

ii. Scales slightly smaller, 31 to 34 in lateral series; D. XVI to XVIII, 12 to 14; pectoral only about three-fourths length of head, not extending to origin of anal; sides often without bars, sometimes with blotches along lateral line; sides of head spotted. .guttulatum.

aa. Teeth more or less flattened, but with conical apices; fold of lower lip not continuous, being interrupted anteriorly.

$j$. Sides with about 9 dark crossbars, the first two bent forward across nape; no dark spots on scales; D. XVII to XIX, 8 or 9; A. VIII to X, 5 to 8 ; scales

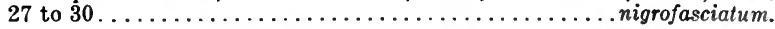

$j j$. Sides with 5 or 6 more or less interrupted bars, forming a series of blotches above lateral line, and another series at or somewhat below middle of side; no bars on nape; scales and vertical fins with dark spots; D. XVII,

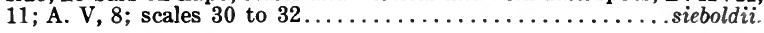

Cichlasoma altifrons (Kner and Steindachner).

Heros altifrons Kner and Steindachner, Abhandl. Bayer. Akad. Wiss., München, 10, p. 11, pl. 2, fig. 1, 1864-"New Granada."

This species was omitted from our earlier publication because of the uncertainty regarding the type locality. It is now included in the fauna of Panama, principally because specimens have been recorded from the Atlantic slope of extreme western Panama by Behre (1928, p. 321). 
The type locality given for this species by Kner and Steindachner is "New Granada," or Colombia. However, Eigenmann (1922) did not record it from Colombia, and it has not been taken in eastern or central Panama by us or, according to the records available, by other collectors. If I interpret Günther (1868, p. 459) correctly, he indicated without qualification that the types came from Chiriqui, Pacific slope of western Panama. Regan (1908, p. 463) recorded it from the Rio Grande de Térraba (Pacific slope), Costa Rica. Meek (1914) did not take this species in Costa Rica, and it was not included in a collection from that country made by Dr. Anastasio Alfaro, reported upon by me (1930). The species may be rather rare and the distribution peculiar. According to the records, as already shown, the species occurs in Colombia, both slopes of western Panama and the Pacific slope of Costa Rica.

Head about 2.75 ; depth 2.3 ; D. XVI, 11 ; A.V, 8 or 9 ; scales 31 to 33 .

Snout notably longer than postorbital part of head; eye 4 to 5 in head; mouth rather small, nearly terminal; maxillary not reaching eye; lips thick, the fold of the lower one split anteriorly; teeth conical, the outer and anterior ones scarcely enlarged; cheeks with 4 or 5 series of scales; dorsal spines graduated, the last one scarcely half the length of head; caudal rounded to more or less truncate; pectoral scarcely reaching origin of anal.

Color brownish; sides with 4 or 5 dark bars; body, and vertical fins exclusive of spinous parts, spotted (condensed after Kner and Steindachner).

\section{Cichlasoma motaguense (Günther).}

Heros motaguense Günther, Trans. Zool. Soc. Lond., 6, p. 462, pl. 77, fig. 3, 1868-Rio Motagua, Guatemala.

This cichlid is included in the Panama fauna on the basis of specimens recorded by Behre (1928, p. 320), collected in the Atlantic drainage of extreme western Panama.

Head 2.35 to 2.8 ; depth 2.2 to 3 ; D. XVII to XIX, 10 to 12 ; A. VII or VIII, 8 to 10 ; scales 30 to 32 .

Body rather elongate and robust; caudal peduncle short; its depth 2.55 to 3 in head; snout nearly as long as postorbital part of head, 2.4 to 2.7 ; eye 3.25 to 6.1 ; mouth moderately large, oblique, lower jaw projecting, maxillary nearly reaching eye; lower lip with an uninterrupted fold; teeth conical, the anterior pair in upper jaw enlarged, canine-like; 5 or 6 rows of scales between lateral line and 
origin of dorsal; about 8 series on cheek; dorsal spines graduated, the last one scarcely a third the length of head, caudal broadly rounded; pectoral fins reaching scarcely to tip of ventrals and not quite to origin of anal, 1.5 to 1.7 in head.

Color dark green to bluish above, more or less silvery underneath. Sides with dark blotches, forming an interrupted lateral band. Young with crossbars and a more pronounced lateral band. Body and head, except snout, with rusty spots, which are present also on the vertical fins (described from specimens collected in El Salvador).

The range apparently extends from British Honduras (Belize), the Rio Motagua, Guatemala, to the Atlantic slope of western Panama, though it does not seem to have been recorded from intermediate localities. On the Pacific slope it has been recorded from several lakes in El Salvador (including Lake Guija, which is partly in Guatemala).

\section{Cichlasoma calobrense Meek and Hildebrand.}

Cichlasoma calobrense Meek and Hildebrand, Field Mus. Nat. Hist., Zool. Ser., 10, p. 90, 1913-Rio Calobre, Panama; p. 346, pl. 29, 1916.

This cichlid is recorded from the Bayano and Tuyra basins in our earlier work (1916, p. 346), the type being from the Rio Calobre, a tributary of the Bayano. Breder (1927, p. 140) reported it from the Chucunaque Basin from near Yavisa. Although the species has not been taken in the vicinity of the Canal Zone, and never before in the Atlantic drainage, Behre (1928, p. 322) recorded it from the Atlantic slope on both sides of the Panama-Costa Rica border.

Cichlasoma umbriferum Meek and Hildebrand.

Cichlasoma umbriferum Meek and Hildebrand, Field Mus. Nat. Hist., Zool. Ser., 10, p. 88, 1913-Rio Cupe, Cituro, Panama; p. 347, pl. 30, 1916.

This species was reported from the Rio Tuyra by us (1916, p. 347 ), the type being from the Rio Cupe, one of the larger tributaries. Breder (1927, p. 140) found it common in the Rio Sucubtí, an upper tributary of the Rio Chucunaque, where he took specimens up to $340 \mathrm{~mm}$. in length, which are much larger than any seen by us.

Eigenmann (1922, p. 207) reported this cichlid from the "Chepo, Tuyra, Atrato, and Magdalena basins." We have no record of its occurrence in the Chepo River and believe that "Chepo" was included by mistake. Therefore, its habitat, so far as known to date, is restricted to the Tuyra, Atrato, and Magdalena basins. 
Cichlasoma tuyrense Meek and Hildebrand.

Cichlasoma tuyrense Meek and Hildebrand, Field Mus. Nat. Hist., Zool. Ser., 10, p. 89, 1913-Rio Tuyra, Boca de Cupe, Panama; p. 344, pl. 28, 1916.

This species, reported from the Bayano and Tuyra basins in our earlier work (1916, p. 344), has since been reported (Breder, 1927, p. 140 ), also from the Rio Chucunaque, a large tributary of the Tuyra not visited by us. It is not reported from the Canal Zone and westward.

Gichlasoma spilurum (Günther).

Heros spilurus Günther, Cat. Fish. Brit. Mus., 4, p. 289, 1862-Lake Yzabál, Guatemala.

This fish is included here because of a record by Behre (1928, p. 321), who took it in the Atlantic drainage of extreme western Panama. Dr. Behre remarked: "This species has hitherto been described no farther south than the Atlantic slope of Guatemala, La Yzabál and Rio Motagua, except in the Canal Zone. It is strange that we should have found no examples from any except the southern limit of our territory. The only Canal Zone specimen available for comparison has been injured anteriorly so seriously as to invalidate measurements." I know of no Canal Zone record, other than this one by Dr. Behre, and have never taken a specimen there. If Dr. Behre's record is based solely on the injured specimen mentioned it may be that the identification is not reliable. In making the remarks quoted, Dr. Behre apparently overlooked the records by Meek (1914, p. 126) who took this species in Costa Rica in both the Atlantic and Pacific drainages.

Head 3 ; depth 2 ; D. XVIII or XIX, 9 or 10 ; A. VIII to X, 7 or 8 ; scales 28 to 30 .

Snout as long as or somewhat longer than postorbital part of head, eye 3 to 4 times in head; mouth very small, terminal, the maxillary not nearly reaching the eye; fold of lower lip interrupted anteriorly; teeth in jaws pointed, the outer ones somewhat enlarged; 2 to $21 / 2$ rows of scales between lateral line and beginning of soft dorsal, 4 or 5 series on cheek; last dorsal spine 1.8 to 2 in head; caudal rounded or subtruncate; pectoral as long as or longer than head, reaching third to fifth anal spine, 1.15 in head.

Color olive green with 7 to 9 dark vertical bars; a large black spot or vertical bar at base of caudal; vertical fins dusky, sometimes spotted. Although the description was compiled from published accounts, the characters were checked from specimens in the United States National Museum, collected in Guatemala.

The range probably extends from Guatemala to western Panama. 


\section{Cichlasoma maculicauda Regan. "ChOGoRro."}

Cichlasoma maculicauda Regan, Ann. Mag. Nat. Hist., (7), 16, p. 227, 1905Lake Yzabál and Rio Motagua, Guatemala, Rio Chagres, Panama; Meek and Hildebrand, Field Mus. Nat. Hist., Zool. Ser., 10, p. 343, 1916.

Heretofore this species has been recorded in Panama only from the lower part of the Chagres Basin. In 1935 and 1937 it was taken on the Pacific side of the divide on the Canal Zone, namely, in Pedro Miguel Locks, Miraflores Lake, and in the upper chamber of Miraflores Locks. These places it apparently has reached by migrating through Culebra Cut. On the Atlantic side it was secured in Gatun Lake at Barro Colorado Island, at several places between Gamboa and Madden Dam; and also in the uppermost chamber of Gatun Locks. This fish seems to be fairly common both in Gatun and Miraflores lakes, as numerous specimens were taken.

This cichlid resembles the bluegill sunfish (Lepomis incisor), in the general shape of the body, in size, and somewhat in color. It is believed, therefore, that those few American residents of the Canal Zone who have reported the successful introduction of the bluegill sunfish (planted in Gatun Lake two or three different times, some years ago) have mistaken this cichlid for that sunfish, which apparently failed to become established. Its qualities as a food fish were not sampled by me, though an American at Pedro Miguel, who believed the fish to be the bluegill, said it was a good pan fish.

I could learn nothing of the game qualities of this cichlid from the local residents, and did not take the time to learn something about them at first hand. The fish, no doubt, is chiefly carnivorous, as shown by its teeth, the short alimentary canal, and the contents of the five stomachs examined. The principal food appears to consist of small mollusks. One specimen contained a great mass of debris, which apparently was in part plant tissue. Its prominent pharyngeal teeth are apparently well adapted to crushing shells. As this fish has a small mouth, small hooks would be necessary, and the bait apparently should consist of a small animal or of meat. Since the fish appears to be a bottom feeder, it should be fished for at or near the bottom. Because of its abundance, this species, if it can be induced to take the hook, apparently would be the most promising as a game fish of any indigenous species in the artificial lakes of the Canal. It grows sufficiently large to have value as a food fish, as many examples ranging from 250 to $320 \mathrm{~mm}$. in length were taken.

This fish is readily recognized among Panama species by the deep body, the depth being contained in the standard length about 
1.8 to 2.1 times; by the large scales, there being only 31 to 33 in a lateral series; and by the large black blotch on the peduncle at the base of the caudal. Frequently a second black blotch appears on the side below the posterior half of the spinous part of the dorsal. Very young have a dark lateral band, but distinct dark bars are wanting. The dorsal is composed of 17 (sometimes 16 or 18) spines and 11 to 13 soft rays; and the anal of 6 spines and 9 (sometimes 8 or 10 ) soft rays.

Five fish, taken in February, were dissected. One female contained large roe, indicating that spawning probably takes place during the dry season. Males do not develop a very prominent nuchal hump, as in some of the other species of this family.

The natural range as now understood extends from British Honduras (Belize) to Panama on the Atlantic slope. The occurrence in Miraflores Lake, herein reported, apparently is the result of migration from the Atlantic to the Pacific slope through Culebra Cut. It is to be remarked that C. maculicauda was not contained in a rather large collection from Costa Rica, reported upon by Meek (1914); neither was it included in collections from that country studied by the writer (1930); and Behre (1928), who collected extensively on the Atlantic slope of both sides of the Panama-Costa Rica border, failed to get it. It is strange, therefore, that this species is unreported, except for a record by Fowler (1916, p. 399), without comment, from Port Limón, Costa Rica, in the territory between the Canal Zone and the Motagua Basin, Guatemala. It is possible that upon comparison of specimens from the Chagres and the Motagua basins, which is not possible for me at this time, it may be found that the fish from the two river systems are not identical, though no differences are evident from published descriptions.

\section{Cichlasoma lethrinus Regan.}

Cichlasoma lethrinus Regan, Ann. Mag. Nat. Hist., (8), 2, p. 462, $1908-$ Rio Iroquois, Costa Rica.

This species was taken by Behre $(1928$, p. 322) in streams of the Atlantic drainage on both sides of the Panama-Costa Rica border. It has been recorded from both slopes of Costa Rica (Meek, 1914, p. 126).

Head 2.66 to 3 ; depth 2.33 ; D. XVII or XVIII, 10 to 12 ; A. VI or VII, 8 to 10 ; scales 29 to 31 .

Snout equal to or a little longer than postorbital part of head; eye 3.5 to 4.5 in head; mouth terminal; maxillary not extending to eye; fold of lower lip interrupted anteriorly; teeth in outer series in 
both jaws somewhat enlarged anteriorly, gradually decreasing in size laterally; $2 \frac{1}{2}$ rows of scales between lateral line and beginning of soft part of dorsal, 4 to $4 \frac{1}{2}$ at origin of dorsal, 5 series on cheek; dorsal spines subequal from fifth to fifteenth, the last about 3 in head; caudal rounded; pectoral not much shorter than head, extending to above first or second anal spine.

Body with 6 dark crossbars, the first two broad and more or less confluent; a more or less continuous blackish longitudinal band from the eye to a spot on the upper part of the base of the caudal; vertical fins dusky, the soft dorsal and caudal with series of pale spots (condensed after Regan's original description).

Known from both slopes of Costa Rica and from the Atlantic slope of extreme western Panama.

\section{Cichlasoma guttulatum (Günther).}

Heros guttulatus Günther, Proc. Zool. Soc. Lond., 1864, p. 152; Trans. Zool. Soc. Lond., 6, p. 466, pl. 78, fig. 3, 1868-Lake Amatitlán, Guatemala.

This species, as well as several other cichlids, is included here in the fauna of Panama on the basis of specimens reported from the Atlantic slope of extreme western Panama by Behre (1928, p. 321). So far as I am aware it has not been reported from localities between Lake Amatitlán, Guatemala, and the Atlantic slope of far western Panama.

Head 2.8 to 3.4 ; depth 2.25 to 2.6 ; D. XVI to XVIII, 12 to 14 ; A. VI or VII, 9 or 10 ; scales 31 to 34 .

Snout nearly as long as, or in large examples somewhat longer than, postorbital part of head; eye 3 to 4.65 in head; mouth rather small, nearly terminal; maxillary not reaching eye; fold of lower lip interrupted anteriorly; teeth conical, the anterior ones somewhat enlarged; 5 series of scales on cheek, $31 / 2$ to $4 \frac{1}{2}$ between lateral line and beginning of soft part of dorsal; the last dorsal spine about 4 in head; caudal subtruncate or rounded; pectoral not reaching origin of anal, 1.33 in head.

Color brownish; a broad dark band extending from above pectoral to base of caudal, this band sometimes interrupted, forming blotches; some specimens with 5 or 6 crossbars; sides of head and body, as well as the vertical fins, often spotted. (Though the description was compiled from published accounts, the characters were checked from specimens in the National Museum, taken in Lake Amatitlán, Guatemala.)

The range apparently extends from southern Mexico (Rio de Sarabia) to the Atlantic slope of extreme western Panama. 
Cichlasoma nigrofasciatum (Günther).

Heros nigrofasciatus Günther, Trans. Zool. Soc. Lond., 6, p. 452, pl. 74, fig. 3, 1868-lakes Atitlán and Amatitlán.

This species was recorded from the Atlantic drainage from both sides of the Panama-Costa Rica border by Behre (1928, p. 323). It has been reported also from lakes Atitlán and Amatitlán (type localities) in Guatemala, from several lakes and streams in El Salvador, and from some rivers of the Pacific slope of Costa Rica.

Head 2.55 to 3.35 ; depth 1.9 to 2.25 ; D. XVII to XIX, 8 or 9; A. VIII to X, 5 to 8 ; scales 27 to 30 ; vertebrae $13+15$.

Body compressed, short and deep; caudal peduncle short and deep, its depth 1.7 to 2.5 in head; snout shorter than postorbital part of head, 2.4 to 3.3 in head; eye 3.2 to 4.6 ; mouth small, terminal; maxillary failing to reach eye, 3.25 to 4.15 in head; fold of lower lip interrupted anteriorly; outer series of teeth in jaws somewhat enlarged and compressed, but with conical apices; 4 or 5 rows of scales on cheek, 4 complete rows between lateral line and origin of dorsal; dorsal spines graduated, the last one equal to postorbital part of head; caudal fin broadly rounded; pectoral reaching to or beyond origin of anal, 1.05 to 1.4 in head.

Color grayish green above, pale pinkish with silvery reflections below. Sides with 9 black bars, the first and second bent forward across nape, the second often meeting the third one on middle of side to form a V. Fins all dusky to black (description based on specimens from El Salvador and the Pacific slope of Costa Rica).

This species has been placed by some authors under Paraneetroplus, a genus based principally on the shape of the outer teeth in the jaws, which are described as somewhat flattened, but with rounded and pointed apices. Others have questioned the validity of this character, because of variation in the shape of the teeth. That considerable variation in dentition may occur within one species was pointed out by Meek (1914, p. 124) and by the present writer $(1930$, p. 8$)$. Because of these variations this species is placed in the genus Cichlasoma herein, as in our earlier work.

This species ranges from lakes Atitlán and Amatitlán, Guatemala, to the Atlantic slope of extreme western Panama.

\section{Cichlasoma sieboldii (Kner and Steindachner).}

Heros sieboldii Kner and Steindachner, Abhandl. Bayer. Akad. Wiss., München, 10, p. 13, pl. 2, fig. 2, 1864-New Granada and the west slope of the Isthmus of Panama; Meek and Hildebrand, Field Mus. Nat. Hist., Zool. Ser., 10, p. 345, 1916. 
This species was included in our earlier publication (1916, p. 345), because the original describers gave as type localities "New Granada" and the "west slope of the Isthmus of Panama." No streams or definite localities were named as places of capture of the 11 specimens, 125 to $200 \mathrm{~mm}$. long, described. This cichlid was not reported from Colombia by Eigenmann (1922), and it apparently has not been seen in Panama since the record by Kner and Steindachner, unless the specimens reported under the name Paraneetroplus sieboldii by Behre (1928, p. 323) from the Rio Chiriquí del Tire (Pacific slope of western Panama) are the same. The identity is questioned by Dr. Behre, for she stated: "Our specimens are probably the same fish as $P$. sieboldii from Costa Rica, Regan, not C. sieboldii from Panama." It is not clear just what the writer had in mind. Regan (1907, p. 30) described Herichthys underwoodi from Costa Rica, which he later in the same publication (p. 186) synonymized with $H$. sieboldii Kner and Steindacher. If Dr. Behre meant to say that Regan's sieboldii from Costa Rica is different from Heros sieboldii Kner and Steindachner, then her specimens should stand as C. underwoodi (Regan). Meek (1914, p. 127), in fact, so recognized his specimens from Costa Rica.

I have examined a specimen in the National Museum (No. 102273) from the Quebrada de India, one of the tributaries of the Rio Coto (Pacific slope), Costa Rica, which agrees in seemingly all important characters with the description and figure of $C$. sieboldi (Kner and Steindachner). I am inclined therefore to follow Regan (1908, p. 186) in assuming that the Costa Rican material is identical with that described and figured by Kner and Steindachner.

The following proportions and counts are based on the Costa Rica specimen examined, which is $130 \mathrm{~mm}$. long (standard length $102 \mathrm{~mm}$.): Head 3; depth 2.5; D. XVII, 11; A. V, 8; scales 30. Snout scarcely longer than postorbital part of head, 2.25 in head; eye 4.25; interorbital 2.6; maxillary 3.8; caudal peduncle (depth) 2.25; longest dorsal spine 3.4 ; longest anal spine 2.8 ; pectoral 1.35 . The outer teeth in both jaws are wide at the base, but the tips are pointed. The lateral line, at the point of interruption, begins again on the third row of scales below its original course. A slight indication of a dark lateral band is present; also a small caudal spot; on the upper half of the sides are dark blotches suggesting crossbars. The membranes of the dorsal and anal bear distinct black spots, which are indefinite on the caudal fin, and missing on the paired fins.

If the types of $C$. sieboldii (Kner and Steindachner) actually were collected in New Granada and on the west slope of the Isthmus of 
Panama, it seems strange that this species was not taken there in the rather extensive collecting done in these regions since the beginning of the present century.

This species, as already stated, is too imperfectly understood to state its range definitely. According to records it apparently occurs from Costa Rica to Colombia.

Neetroplus panamensis Meek and Hildebrand.

Neetroplus panamensis Meek and Hildebrand, Field Mus. Nat. Hist., Zool. Ser., 10, p. 90, 1913-Rio Mandingo, Bas Obispo, Canal Zone; p. 348, pl. $31,1916$.

This species was taken by us in several places in the Chagres Basin in 1911 and 1912. During the recent investigation it was found only in a creek, tributary to Gatun Lake, on Madden Dam Road where 11 specimens ranging in length from 38 to $95 \mathrm{~mm}$. were seined. To date no evidence has been found indicating that this fish has established itself in the artificial lakes of the Canal. It apparently does not grow large, as no specimen more than $103 \mathrm{~mm}$. long has been recorded.

This species differs from the others of the family known from Panama in having the anterior teeth in each jaw flattened, that is, more or less incisor-like, and with unindented cutting edges. The anal fin consists of 6 , rarely 7 , spines and 7 soft rays, and the dorsal has 17 or 18 spines and 9 or 10 soft rays.

The young have rather definite dark crossbars. The one lying under about the twelfth and thirteenth spines is broadened toward the middle of the side and intensely black, and a black caudal spot is present. In adults the bars fade and sometimes disappear, but the black blotch on the side, and generally the caudal spot, remain. Frequently other dark blotches are present on the side in adults. The following remarks concerning color are based on a fresh specimen $95 \mathrm{~mm}$. long: General color dark olivaceous above, pinkish below. Many scales on sides with pearly spots, which are present also on the vertical fins.

This species had been reported only from the Chagres Basin until Breder (1927, p. 140) reported it somewhat doubtfully from a single specimen, $82 \mathrm{~mm}$. long, from the Rio Chucunaque, in eastern Panama. Mr. J. T. Nichols of the American Museum of Natural History has kindly sent me Mr. Breder's specimen for study. After comparing it with Chagres River specimens I am convinced that it is a true $N$. panamansis. The scale and fin-ray counts agree perfectly, and the proportions come well within the range of Chagres River 
specimens. Although the color markings on the sides of this specimen, which is presumably a male, are not as distinct as in some males from the Chagres, they are similarly placed. In general, the dark color markings are less distinct in males than in females, but males have pale spots (probably pearly in life) on the soft dorsal and less distinctly on the caudal, which the females do not possess. These markings on the fins are rather more distinct on the Chucunaque specimen than on any Chagres River fish at hand.

This species is known from the Chagres Basin, where it is common, and from a single specimen from the Tuyra Basin.

Herotilapia Pellegrin.

This genus differs from Neetroplus only in having the compressed, incisor-like teeth tricuspid instead of having a continuous cutting edge. This genus is not included in our earlier (1916) work.

Herotilapia multispinosa (Günther).

Heros multispinosus Günther, Trans. Zool. Soc. Lond., 6, p. 453, pl. 74, fig. 2, 1868-Lake Managua, Nicaragua.

This species is included in the Panama fauna on the basis of a record by Behre (1928, p. 324) who collected specimens (not seen by me) in the Atlantic drainage on both sides of the Panama-Costa Rica border.

This cichlid is readily distinguished from other species in Panama by its tricuspid incisor-like teeth, a character recognized as of generic importance. The dorsal consists of 18 spines and 9 soft rays, and the anal of 11 spines and 7 or 8 soft rays. The scales are large, only 28 or 29 being present in a lateral series. The color is brownish olive, each scale being somewhat darkened at the base. A blackish lateral band extends from the eye to the base of the caudal, but is more or less broken posteriorly by dark blotches, indicative of bars, with a definite black blotch on the side below the posterior half of the spinous part of the dorsal.

The range apparently extends from Nicaragua (Lake Managua) to the Atlantic slope of extreme western Panama, the species being recorded only from the type locality, Lake Managua, and from the Atlantic drainage from both sides of the Panama-Costa Rica border.

\section{Family GOBIIDAE. Gobies}

The family Gobiidae, as formerly understood, has been divided by some recent authors who recognized those forms that have the ventral fins separate, that is, not united to form a sucking disk, as 
a distinct family under the name Eleotridae. The present writer has no fault to find with this division, though he has found remarkable similarity in the appearance and development of the young. For convenience the species from the fresh waters of Panama are treated here as one family, as in the earlier work by Meek and Hildebrand (1916). Only two genera, Awaous and Sicydium, with united ventrals are included.

The fresh and brackish water gobies (Eleotridae) are more numerous as to species in Panama than elsewhere. Thirteen species with separate ventrals are recognized in the following pages. None is common to both slopes (except the few that have recently "crossed over" through the Canal), though five species of each slope have extremely close relatives on the opposite sides, leaving only two on the Atlantic and one on the Pacific slope without near relatives. Contrary to the other fresh-water families of Panama, this group seems to have its center of distribution on the Isthmus of Panama.

Gobiomorus Lacépède. Guavina.

Gobiomorus has replaced Philypnus, long used for this genus, on the basis of priority.

Only two species of this genus, both occurring in Panama, are known. They are rather sluggish carnivorous fishes, generally occupying shallow weedy areas where they lie quietly, hiding more or less among the plants, from which they make quick excursions, if hunger prompts them, to seize almost any animal of suitable size that comes near.

Although the species reach a sufficiently large size they do not seem to find much favor as food fishes.

Gobiomorus dormitor Lacépède.

Gobiomorus dormitor Lacépède, Hist. Nat. Poiss., 2, p. 599, 1798-Martinique, from a drawing by Plumier.

Philypnus dormitor Meek and Hildebrand, Field Mus. Nat. Hist., Zool. Ser., 10, p. $350,1916$.

Thirty specimens of this species, ranging in length from 35 to $185 \mathrm{~mm}$., were preserved, and others were examined in the field. These specimens were collected at Cativa, and in Gatun Lake at Gatun, Barro Colorado Island, and a short distance below Madden Dam.

As this species and its Pacific slope congener, maculatus, were common in the waters of the Canal Zone before the opening of the Canal, according to investigations made in 1911 and 1912, crossing 
over through Culebra Cut, and intermingling of the species would be expected. Although maculatus has entered Gatun Lake, as shown in the discussion of that species, no evidence indicating that dormitor has crossed over to Miraflores Lake and adjacent waters was gained.

This species is rather close to maculatus, yet the two are readily separable by the differences in the scale and anal fin formulae, and color. In 20 specimens of dormitor 19 have I, 9 anal rays and one has $\mathrm{I}, 10$, whereas in 23 specimens of maculatus, 21 have I, 10 rays and one has I, 11, the last partly divided ray having always been counted as one. In the same specimens the number of oblique series of scales between the upper anterior angle of the gill opening and the base of the caudal ranges from 62 to 66 , and the complete longitudinal rows between the bases of the second dorsal and anal from 19 to 22 in dormitor, and 55 to 60 and 17 or 18, respectively, in maculatus. In color, dormitor differs principally in having much larger and more prominent dark spots on the dorsal, caudal, and pectoral fins. Generally the dark lateral band is much more prominent in dormitor, and it persists more or less in large specimens, whereas it is not evident in the larger specimens of maculatus, nor even in some of the young.

This fish reaches a length of about 325 to $375 \mathrm{~mm}$. Although used as a food to a limited extent, it is not valued highly.

This species ranges from Texas to Brazil and the West Indies. It is common in brackish and fresh-water lowland swamps and streams, and it also ascends rivers in which it occupies shallow weedy coves. It has been taken in all suitable localities on the Atlantic slope of Panama where collections have been made. Behre $(1928$, p. 311$)$ recorded it from extreme western Panama, from the province of Bocas del Toro.

Gobiomorus maculatus (Günther).

Lembus maculatus Günther, Cat. Fish. Brit. Mus., 1, p. 505, 1859-Andes of Ecuador.

Philypnus maculatus Meek and Hildebrand, Field Mus. Nat. Hist., Zool. Ser., 10, p. 352, 1916.

Thirty-one specimens, ranging in length from 40 to $210 \mathrm{~mm}$., were preserved, and others were examined in the field. The specimens were collected in Gatun Lake, Miraflores Lake, Rio Cocoli, Pedro Miguel Locks, upper and lower chambers of Miraflores Locks, Rio Cabra, and in some small coastal streams crossing the National Highway between Campaña and La Venta. 
As noted in the preceding paragraph, the species was taken in Gatun Lake, the catch consisting of two specimens, 127 and $210 \mathrm{~mm}$. long, caught in the lake only a short distance below Madden Dam. These two specimens are typical maculatus, that is, they appear to be identical with specimens from streams of the Pacific slope of Panama not connected with the Canal. Although the two species must be living together, as shown by three specimens of dormitor and two of maculatus, taken together in one cove of Gatun Lake, no indication of cross-breeding is evident. However, a specimen, $147 \mathrm{~mm}$. long, from Barro Colorado Island has some of the characters of both species, but it also differs from both. It agrees with dormitor in the scale formula (64-22), and in color; it agrees with maculatus in the anal fin formula (I, 10); but it differs from both in the more slender body (depth 6.6, and peduncle 11.6 in standard length), in the larger eye (5.25 in head, compared with about 6 to 6.5 in other specimens of about equal length), and in having one more spine and one more ray in the dorsal fins, the formula being VII-I, 10. In the absence of similar specimens, supplying more evidence of cross-breeding, or that a third species is present, the specimen is regarded, for the present, as a variant dormitor.

This fish apparently reaches a length about equal to that of dormitor, the largest individual seen being $325 \mathrm{~mm}$. long.

The range of this species extends from Lower California to Ecuador. It lives in environments similar to dormitor and seems to be identical with that species in its behavior and selection of food.

\section{Dormitator Gill. GuAvina.}

Two very closely related species from the opposite slopes of Panama are recognized. The relationship, which is discussed in the following accounts, is so close, however, that the species must be regarded as doubtfully distinct.

The common name, guavina, seems to be widely used in Central America and the West Indies for the species of this genus and for those of related genera.

\section{Dormitator maculatus (Bloch).}

Sciaena maculatus Bloch., Naturgesch. Ausland., Fische, pl. 299, fig. 2, 1790 - West Indies.

Dormitator maculatus Meek and Hildebrand, Field Mus. Nat. Hist., Zool. Ser., 10, p. 354, 1916.

Specimens of this species were taken at Fort Sherman (Toro Point), and at Cativa, on the Atlantic side. In addition 15 small 
specimens, ranging in length from 20 to $85 \mathrm{~mm}$., taken in the lower flight (east side) of Miraflores Locks, seem to be of this species. If the last-mentioned specimens are correctly identified, it would appear that a migration from the Atlantic to the Pacific side, through the Canal, had taken place. The Pacific drainage representative of the genus, namely, latifrons, was not taken in the Miraflores Locks when they were dewatered, but was secured there later. The relationship between the two species, as shown subsequently, is so close that too much reliance must not be placed on the identification of juveniles. Other specimens taken in the Pacific drainage certainly are separable from the Atlantic ones, and are in entire agreement with the differences stated by Meek and Hildebrand (1916, pp. 353-356), based on a study of specimens collected in 1911 and 1912.

This species apparently differs from latifrons chiefly in having somewhat fewer scales, and rather longer pectoral and ventral fins, as shown in the counts and measurements given subsequently. Furthermore, the mouth seems to be a little more strongly oblique in maculatus than in latifrons, as the cleft anteriorly is generally well above the lower margin of the eye, whereas in the latter it is usually about.at the level of the lower margin of the eye.

The following measurements and counts are based on seven small specimens ranging in length from 45 to $85 \mathrm{~mm}$., no larger specimens of this species having been secured during the recent investigation: Head 3.2 to 3.4 ; depth 3.7 to 4 ; D. VII-I, 8 (if the last partly separated ray is counted as 1 ); A. I, 8 or 9 ; P. 14; scales 30 to 33,7 to 9 complete longitudinal rows between the base of dorsal and anal. Snout 3.3 to 4 in head; eye 4 to 4.7 ; interorbital 2.5 to 3.2 ; maxillary 3.3 to 3.5 . Pectoral 1.1 to 1.5 in head, 3.7 to 4.1 in standard length; ventral 1 to 1.2 in head, 3.4 to 3.9 in standard length.

This species, like its Pacific slope relative, lives in still, brackish and fresh water, often being found in very shallow warm stagnant pools and coves, where it feeds on algae and other plants. Although primarily a vegetarian in nature, this species and its relatives have been used very successfully in South America for the control of mosquito-breeding in water containers. When plants are not present they feed on wiggle-tails; they live well in confinement; and are too sluggish (or sleepy, as the generic name indicates) to jump out of even a brimful container, a difficulty experienced with the top minnows, which in nature are far better for mosquito control. It must not be assumed that these guavinas are useful in nature for 
mosquito control, because they feed on wiggle-tails when confined in comparatively small containers wherein algae and other plants, which constitute their usual food, are absent. Apparently in the absence of the usual diet they take what is available and exist on it.

This fish as now understood ranges on the Atlantic slope from North Carolina to Para, Brazil, and the West Indies. During the earlier investigations in Panama (1911 and 1912) it was taken in many lowland brackish ponds and streams from Porto Bello to Toro Point, and Behre $(1928$, p. 310$)$ recorded it from extreme western Panama from the province of Bocas del Toro.

Dormitator latifrons (Richardson).

Eleotris latifrons Richardson, Voyage "Sulphur," Fishes, p. 57, pl. 35, figs. 4, 5, 1837-probably Pacific coast of Central America.

Dormitator latifrons Meek and Hildebrand, Field Mus. Nat. Hist., Zool. Ser., 10, p. 355, 1916.

Specimens were taken only in a stagnant pool, wherein they were numerous, in a creek near the head of tide on the National Highway near Campaña, during the recent investigations. Later specimens, taken in Miraflores Locks by Mr. Lear, a Locks employee, were received. D. latifrons seems to be rather common along the Pacific coast of Panama in habitats similar to the first one mentioned above, as it was taken in several such places during the earlier (1911 and 1912) investigations. Meek and Hildebrand did not see it in the Tuyra Basin, but Breder (1927, p. 141) took specimens in a stagnant tidal pool near Yavisa in that river basin.

The relationship between this species and maculatus, as stated in the account of the last-mentioned species, is very close. The following measurements and counts, based on six specimens ranging in length from 47 to $205 \mathrm{~mm}$., are useful in showing the minor differences.

Head 2.75 to 3.1 ; depth 2.8 to 3.2 ; D. VII-I, 8 (if the last partly divided ray is counted as one); A. I, 9; P. 14 or 15 ; scales 34 to 36 , 10 to 12 complete longitudinal rows between the base of dorsal and anal. Snout 3.1 to 3.8 in head; eye 4.8 to 7 ; interorbital 2.1 to 2.75; maxillary 3.1 to 3.5 . Pectoral 1.25 to 1.4 in head, 3.5 to 3.9 in standard length; ventral 1.4 to 1.8 in head, 4.3 to 4.7 in standard length.

The bright or even brilliant color of the fish taken March 11, 1937 , from a very stagnant dirty pool, was striking by contrast. Bright colors had not previously been noticed by me in other specimens, and they may be nuptial, as the brightly colored speci- 
mens were developing males. Specimens taken later (September 30, 1937) in Miraflores Locks, by Mr. Lear, upon which Dr. Foster based color notes, also were brightly colored. The specimens taken by $\mathrm{Mr}$. Lear were schooling in the locks. Dissections made by Dr. Foster and by me show that the fish forming the schools were in spawning condition. Therefore, the fish apparently schooled to carry out their reproduction activities. That this was taking place in the locks is interesting. Spawning, then, would appear to take place during the rainy season-our summer.

The following notes on color were based on a male $200 \mathrm{~mm}$. long, immediately after the fish was caught. Brownish above in advance of dorsal, bluish on sides with indications of lighter crossbars; belly pale gray; head bluish underneath. Many scales on side have a brownish base. Dorsal fin brownish with dark markings and a brilliantly red margin; caudal fin similar in color, but without spots; anal fin green at base, with dark spots, and the outer two-thirds bright red; ventrals bluish green; pectorals wholly pinkish; iris red. That there is variation even among adults is evident from notes taken by Dr. Foster, based on a fish (sex not stated) taken in Miraflores Locks to which reference was made in the preceding paragraph. The following description is condensed after Dr. Foster:

Body blue-green dorsally to inconspicuously greenish red ventrally. Head slate-colored; iris red. Dorsal fin gray with black polka dots and inconspicuous red margins; caudal fin gray; anal fin deep maroon, with 2 or 3 rows of blue polka dots near and parallel to body, the margin conspicuously white; pectorals and ventrals blue-gray.

This fish ranges from Lower California to Ecuador.

Eleotris Bloch and Schneider. Guavina.

Three species of this genus occur in Panama. They are highly carnivorous, and although a sufficiently large size is attained (at least by picta) they are not valued as food, possibly because they are covered with a heavy coat of mucus, which gives them a disagreeably slimy appearance.

The species are distinguished principally by the differences in the size of the scales, their degree of embedding, and by color, as pointed out in the following accounts.

Eleotris picta Kner and Steindachner.

Eleotris picta Kner and Steindachner, Abhandl. Bayer. Akad. Wiss., München, 10, p. 18, pl. 3, fig. 1, 1864-Rio Bayano, Panama; Meek and Hildebrand, Field Mus. Nat. Hist., Zool. Ser., 10, p. 357, 1916. 
Thirty-one specimens, ranging in length from 22 to $480 \mathrm{~mm}$., taken in Pedro Miguel and Miraflores Locks, Miraflores Lake, and in streams crossing the National Highway between Campaña and La Venta, were preserved. Many others were seen and examined. The largest individual seen was a male $495 \mathrm{~mm}$. long, which may be near the maximum size attained. The indication is that this species grows larger than its near relative of the Atlantic slope, the largest specimen of that species seen being only $150 \mathrm{~mm}$. long. In addition, 21 juveniles, ranging in length from 18 to $20 \mathrm{~mm}$., were taken in the lower chamber (west side) of Miraflores Locks, in strongly brackish to salt water. None of these juveniles have the generically distinctive preopercular spine developed. However, it seems evident that the gill openings do not extend forward under the eyes, as in Gobiomorus, which has a similar fin ray count, and the mouth is large with protruding lower jaw. The young, therefore, seem to belong to Eleotris. Although the fins are quite fully developed, general pigmentation has not taken place. In general, the development is more retarded than in Eleotris pisonis and E. isthmensis of equal size, possibly because picta reaches a larger size.

The similarity of these young eleotrids and some young marine gobies, studied by the writer (1938), is striking. In the eleotrids, as in the marine gobies with fully united ventrals, the caudal fin is concave, not becoming round until pigmentation is general. The color markings of the juveniles, too, are similar, consisting in each group principally of black lines composed of short dashes on the median dorsal and ventral lines.

The relationship of this species and pisonis is discussed in the account of the last-mentioned species. The distinctive characters set forth apply to all the specimens preserved or examined, that were not taken in the Canal or waters connected with it, as well as to most of the individuals taken in the Canal. One rather notable exception, and a few less pronounced ones, which have some of the characteristics of both pisonis and picta, however, were found.

The most notable exception is a male specimen, $345 \mathrm{~mm}$. long, taken in Pedro Miguel Locks. It has large scales like pisonis, which as in that species are scarcely or not at all embedded in advance of the dorsal. This fish has 62 oblique series of scales between the upper posterior angle of the gill opening and the base of the caudal on one side and 65 on the other, and 19 complete longitudinal rows between the bases of the second dorsal and the anal. In color this specimen agrees with picta, being quite pale ventrally 
with only scattered brownish dots, and with no indications of dark lines along the rows of scales. This specimen, though having the characteristic concealed spine on the preopercular margin, differs from other specimens in having two small patches of vomerine teeth. The presence of these teeth is difficult to explain, as the genus is not supposed to possess them. Perhaps this specimen is merely a variant in that respect.

One female, $245 \mathrm{~mm}$. long, from the lower flight of Miraflores Locks, though having small scales that are well embedded in advance of the dorsal, as characteristic of picta, nevertheless has rather definite dark lines along the rows of scales on the sides as in pisonis. A few small specimens from Miraflores Lake also have indications of dark stripes along the rows of scales, though less distinct and less definitely continuous.

It cannot be stated positively, because of the close relationship of the two species under consideration, that the specimens discussed, which have some of the characteristics of each species, are hybrids. However, the evidence seems to lead to that conclusion. If they are hybrids, then it follows that the species have intermingled by passing through Culebra Cut, and have cross-bred. As many individuals were present in Pedro Miguel Locks when the locks were dewatered in 1937 it seems probable that they pass through these single flight locks freely. Certainly no reason is evident why the species would not intermingle, as no barrier to prevent it seems to be present.

The sexes in this species may be distinguished by the shape of the anal flap, for in the male it is rather narrow distally, with a strongly convex to almost pointed margin, whereas in the female it is notably broader distally, with an almost straight posterior margin. Spawning apparently takes place during the dry season (about February to April), as five of seven specimens examined, two males and five females, taken February 20 and March 26, 1937, contained either large or developing roe.

Among eight specimens examined for food five had empty stomachs. One of the others had ingested an anchovy and the second one had fed on small mussels. The species is strictly carnivorous, as shown by these examinations and published accounts.

This fish is common in Miraflores Lake, and, as already stated, many individuals were found in Pedro Miguel Locks when the locks were dewatered in February, 1937. The species is not valued as food. Large examples offered to colored workmen were refused, 
possibly because the heavy coating of mucus they always seem to possess makes them repulsive.

This species ranges from Lower California to Ecuador. It has been taken in virtually all the streams sampled in the Pacific slope of Panama. Though it was not secured in the Tuyra Basin by Meek and Hildebrand, it was recorded from there by Breder (1927, p. 142).

\section{Eleotris pisonis (Gmelin).}

Gobius pisonis Gmelin, Linn. Syst. Nat., p. 1206, 1788-Brazil.

Eleotris pisonis Meek and Hildebrand, Field Mus. Nat. Hist., Zool. Ser., 10, p. $358,1916$.

Twenty-four specimens, ranging from 22 to $150 \mathrm{~mm}$. in length, were collected in 1935 and 1937 in fresh-water streams at Fort Sherman (Toro Point), and Cativa; and in the dry dock at Mount Hope, and the lowest chamber (east side) of Gatun Locks. In the dry dock and the lowest chambers of Gatun Locks, the water is quite brackish to salty. In addition to the specimens listed, three juveniles, respectively 14,15 , and $19 \mathrm{~mm}$. long, which apparently belong to this species, were taken in the lowest chamber of Gatun Locks, together with larger ones already listed. The characteristic preopercular spine is well developed in the $19 \mathrm{~mm}$. fish, and it may be felt with a fine needle in the $15 \mathrm{~mm}$. one, but it is not yet evident in the $14 \mathrm{~mm}$. specimen. The $15 \mathrm{~mm}$. specimen already has a few scales on the caudal peduncle where they seem to appear first, but the $14 \mathrm{~mm}$. fish remains naked. This smallest specimen also remains largely unpigmented, whereas in the larger ones, pigmentation is general.

As this species and its Pacific slope congener, picta, ascend freshwater streams and are fairly common, according to investigations made in 1911 and 1912, on both slopes of the Canal Zone in waters now included in or connected with the Canal, crossing over from one side to the other might be expected. However, no evidence that it has taken place was gained from the specimens collected in the dry dock at Mount Hope and Gatun Locks, though the situation is somewhat different in regard to specimens taken in Pedro Miguel and Miraflores Locks, and in Miraflores Lake, as stated in the account of E. picta.

This species differs from its Pacific slope relative, picta, in several minor respects, as pointed out by Meek and Hildebrand (1916, p. 356). The differences in the size of scales and the degree of embedding, together with the differences in color, are the principal recognition marks. The present species has somewhat larger scales 
(59 to 68 , most frequently about 64 in a lateral series, and about 18 complete longitudinal rows between the bases of second dorsal and anal, whereas picta has respectively 63 to 75 , most frequently 67 to 69 , and about 22), and they are not as greatly reduced in size in advance of the dorsal. Furthermore, they are scarcely or not at all embedded on the head in the present species, but rather fully in picta. In general, pisonis is darker ventrally, the color of preserved specimens being uniform brown, and the rows of scales along the sides are more or less distinctly marked with black lines. The ventral surface of the head, chest, and belly in picta, on the other hand, is rather pale, and is dotted, spotted, or marbled with brown, there being much variation among specimens, and there are no continuous dark lines along the rows of scales. Small specimens frequently have a dark band extending backward from the snout and eye. This band is much more frequently present in the Pacific slope specimens than in the Atlantic ones.

This species ranges from Florida to Brazil.

Eleotris isthmensis Meek and Hildebrand.

Eleotris isthmensis Meek and Hildebrand, Field Mus. Nat. Hist., Zool. Ser., 10, p. 359, 1916-Mindi, Canal Zone.

Eleven specimens, ranging from 20 to $60 \mathrm{~mm}$. in length, were collected in 1935 and 1937 at Fort Sherman (Toro Point) and at Puerto Pilón in fresh water, and in brackish to salt water in the lowest chamber of Gatun Locks. In addition, 22 juveniles, ranging from 14 to $18 \mathrm{~mm}$. in length, which evidently belong to this species, were taken in the lowest chamber of Gatun Locks (east side). The smallest of these specimens already are well clothed with ctenoid scales posteriorly. The preopercular spine, characteristic of the genus, is present, and pigmentation is general. The caudal fin, however, remains concave to square. Development seems to be a little farther advanced in these fish than in young of the same size of pisonis, and much ahead of young of similar size of picta.

This species apparently agrees with pisonis in all respects, except that it has larger scales $(45$ to 53 oblique series between the upper posterior angle of gill opening and base of caudal, and 12 to 14 complete longitudinal rows between the bases of the second dorsal and the anal), which seem to be less adherent. The species apparently reaches even a smaller size than pisonis. The largest specimen known is only $85 \mathrm{~mm}$. long, and those 50 to $60 \mathrm{~mm}$. long are sexually fully mature. 
The species is known only from the Atlantic slope of Panama, where it has been taken in or near brackish water. It apparently is rather less common than pisonis.

Guavina guavina (Cuvier and Valenciennes).

Eleotris guavina Cuvier and Valenciennes, Hist. Nat. Poiss., 12, p. 223, 1837 - Martinique.

Guavina guavina Meek and Hildebrand, Field Mus. Nat. Hist., Zool. Ser., 10, p. $360,1916$.

No specimens of this species, which seems to be rather rare in Panama, were secured in 1935 nor 1937. Our earlier collections (1911 and 1912) contained only five specimens, collected in brackish ditches and creeks at Fort Sherman (Toro Point) and Colón.

The range of this fish extends on the Atlantic coast from somewhere in Mexico, through the West Indies, to Brazil.

Leptophilypnus Meek and Hildebrand.

Microeleotris Meek and Hildebrand, Field Mus. Nat. Hist., Zool. Ser., 10, p. 362, 1916-type M. panamensis.

The generic name, Microeleotris, is placed in synonomy here for reasons stated in the account of Leptophilypnus fluviatilis.

Leptophilypnus fluviatilis Meek and Hildebrand.

Leptophilypnus fluviatilis Meek and Hildebrand, Field Mus. Nat. Hist., Zool. Ser., 10, p. 361, 1916-Mindi, Canal Zone.

Microeleotris mindii Meek and Hildebrand, Field Mus. Nat. Hist., Zool. Ser., 10, p. 364, 1916-Mindi, Canal Zone.

This species was numerous in the "manholes" in the floors of the locks, especially in the chambers in which the water was nearly fresh. The fish could be seen clinging, very goby-like, to the walls of the holes in which water remains after the floors of the locks have been drained or pumped dry. The fish are not easily caught, however, as they cling close to the concrete walls of the "manholes," and are able to avoid nets fairly successfully. Specimens were secured in Gatun Locks: (a) uppermost chamber 27 specimens, 15 to $43 \mathrm{~mm}$. long; $(b)$ middle chamber two specimens, 38 and 40 $\mathrm{mm}$. long; and (c) lowermost chamber one specimen, $35 \mathrm{~mm}$. long; in Pedro Miguel Locks, 35 specimens, 20 to $33 \mathrm{~mm}$. long; and in the upper chamber of Miraflores Locks, 16 specimens, 28 to $48 \mathrm{~mm}$. in length. There are none from the lower chamber. In addition, three specimens were seined in Gatun Lake at Barro Colorado Island, and one in Miraflores Lake. 
It was recorded only from a brackish creek at Mindi, Canal Zone (Atlantic side) by Meek and Hildebrand (1916, pp. 361-364), who recorded similar specimens from the same vicinity under the name Microeleotris mindii; and also $M$. panamensis from the Pacific slope from the Rio Chorrera and the Rio Juan Diaz. It should be noted that $M$. panamensis was not taken on the Pacific slope of the Canal Zone. The specimens now at hand cannot be separated definitely as to the genera Leptophilypnus and Microeleotris, which were described as differing chiefly in the width of the dentary bones, or rather as to whether they met at or near the posterior angles of the mouth. In Leptophilypnus they were described as meeting, leaving an oval-shaped naked area at the chin, whereas in Microeleotris these bones were said to be narrow and not meeting. I have re-examined paratypes of all three species placed in these genera,

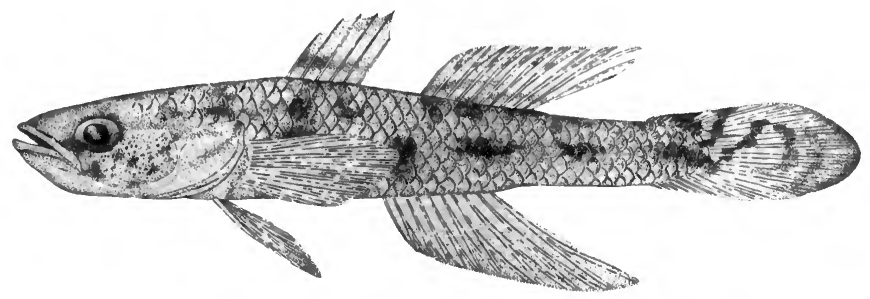

FIG. 10. Leptophilypnus fluviatilis Meek and Hildebrand. Specimen $50 \mathrm{~mm}$. long. (From drawing by Andrew Pizzini.)

in connection with the specimens recently collected. The paratypes of L. fluviatilis are quite uniform as to the width and the approach to each other of the dentary bones, but the type material of $M$. mindii shows considerable variation in this respect, and in the material recently collected there is a wider degree of variation. In some specimens the bones meet and in others they are variously separated, some being fully half an eye's diameter apart. Apparently, the way the fish happens to die, that is, with the mouth open and the gill covers spread, makes a difference, but that does not account for the whole variation. It seems to be true also that typical examples of $M$. mindii have a wider head and a deeper caudal peduncle. However, the intergradation is complete. No tangible differences in the number of fin rays or scales were found among the type material, and I find none among the specimens at hand. I have concluded, therefore, that the genus Microeleotris is 
not valid and that $M$. mindii is a synonym of $L$. fluviatilis. However, $M$. panamensis is a valid species, differing from fluviatilis in having smaller scales, in having (usually at least) 8 instead of 9 soft rays in the second dorsal and in the anal, and in having a broader head, as stated by Meek and Hildebrand (1916, p. 363), but generically it is not distinct.

As L. fluviatilis was not taken on the Pacific slope of the Canal Zone before the opening of the Canal, it seems probable that it has crossed over from the Atlantic. This fish, as already stated, was numerous in those chambers of the locks at both ends of the Canal that are fairly fresh, where it seemed to be peculiarly at home. No reason is known why the members of the species should not migrate freely between the locks at the opposite ends of the Canal. This fish is known only from the Canal Zone.
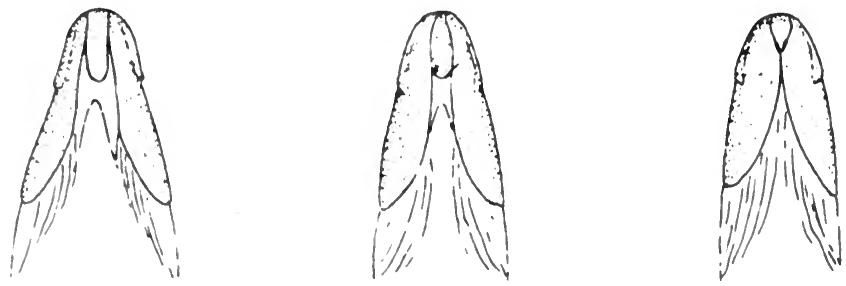

FIG. 11. Leptophilypnus fluviatilis Meek and Hildebrand. Ventral surface of heads of three specimens, showing variation in width and in space between dentary bones.

Leptophilypnus panamensis (Meek and Hildebrand).

Microeleotris panamensis Meek and Hildebrand, Field Mus. Nat. Hist., Zool. Ser., 10, p. 363, 1916-Rio Juan Diaz.

In our earlier work this species was placed in the genus Microeleotris, which proves to be invalid. However, panamensis has been shown to be a valid species. It is not in the present collection, and remains known only from the type material from the Rio Chorrera and the Rio Juan Diaz, which was re-examined in part.

Euleptoeleotris gen. nov.

Genotype Euleptoeleotris clarki sp. nov.

This genus agrees with Eleotris, $(a)$ in having broad bands of teeth on the jaws and none on the vomer, $(b)$ in having the gill openings restricted (extending scarcely to margin of preopercle), and $(c)$ in having a somewhat concealed downward projecting 
spine on the lower posterior angle of the preopercular margin. It differs from that genus, however, $(a)$ in having a much more slender body (depth about 6.5 to 8 in standard length), (b) in having much smaller scales (125 or more in a lateral series), which are all cycloid, and (c) in having more numerous simple or rudimentary caudal rays (11 to 13 above and below), which extend much farther forward on caudal peduncle, about to joint between the third and fourth vertebrae. Vertebrae about 9 or $10+15$ or 16 .

Euleptoeleotris clarki sp. nov.

Type from Miraflores Locks, Canal Zone. No. 106508 United States National Museum. Female. Total length $127 \mathrm{~mm}$., standard length $104 \mathrm{~mm}$.

Description of the type.-Head 4.5; depth 8; D. VI-I, 13; A. I, 11; P. 18; scales too small to enumerate accurately, about 175 in a lateral series.

Body very slender, compressed posteriorly; depth of caudal peduncle 2.4 in head; head depressed, the width exceeding the depth by fully an eye's diameter; snout rather long, 5.1 in head; eye small, directed upward only slightly, 10.2; interorbital 8.2; mouth large, oblique, lower jaw strongly projecting; maxillary reaching under middle of eye, 3.1 in head; gill openings restricted, extending forward scarcely to preopercular margin; scales reduced in size anteriorly, but scarcely embedded; head with many rows of pores, especially around the eyes; dorsal fins well separated, none of the spines of the first reaching the origin of the second if deflexed, the origin of the second about equidistant from the posterior margin of the eye and the base of the caudal; caudal somewhat pointed, the longest rays nearly as long as the head, with 12 rudimentary rays above and 11 below, extending forward on caudal peduncle a distance fully equal to the depth of the peduncle; anal fin similar to second dorsal, its origin about an eye's diameter posterior to origin of second dorsal; ventrals rather small, 2.1 in head; pectorals notably larger, pointed, the middle rays being somewhat produced, reaching about half their length beyond tips of ventrals, 1.5 in head.

Color of preserved specimen uniform light brown above, paler ventrally, the chest and abdomen being pale with many dark dots; a dark blotch behind upper part of gill opening; sides with indications of pale cross lines except on peduncle. Dorsal and pectoral fins rather pale with blackish spots, the latter with a dark blotch at base; caudal darker, with indications of black spots; anal and ventrals pale, with scattered dark points. 
Variations noticed in the paratypes are as follows: Head 4 to 4.6 ; depth 7.5 to 8.5 ; D. VI-I, 12 or 13 ; A. I, 10 or 11 ; P. 17 to 19 ; rudimentary rays of caudal 11 or 12 both above and below peduncle; scales too small to enumerate accurately, about 150 to 175 ; vertebrae $9+15$ or 16 . Snout 5 to 5.6 in head; eye 8.4 to 10.2 ; interorbital 5.5 to 8.5 ; maxillary 2.8 to 3.2 ; ventral fin 2 to 2.4 ; pectoral 1.4 to 1.8; caudal peduncle 2.4 to 3 . Some specimens are paler than others. The paler specimens have no definite dark blotch on the base of the pectoral.

The sexes in this species, as in Eleotris, can be recognized by the shape of the anal flap, that of the female being broadly rounded to nearly square distally, whereas in the male it is somewhat pointed. In general, the dorsal and anal fin rays seem to be somewhat higher in males than in females. It is not evident that the caudal fin is longer in males than in females, nor that it increases in proportionate

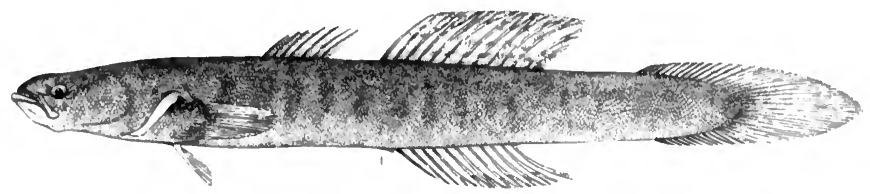

Fig. 12. Euleptoeleotris clarki gen. et sp. nov. Type, female, $127 \mathrm{~mm}$. long. (From drawing by Andrew Pizzini.)

length with age, the length varying from slightly shorter to slightly longer than the head.

This species is represented in the collection by 11 specimens, ranging in length from 63 to $150 \mathrm{~mm}$., all taken in Miraflores Locks, partly in the upper and partly in the lower chambers.

It affords me pleasure to name this species for Dr. Herbert C. Clark, director of the Gorgas Memorial Laboratory, who made it possible to carry on the investigations resulting in the discovery of this and several other new species of Panamanian fishes.

Euleptoeleotris shropshirei sp. nov.

Type from a dry dock, Mount Hope, Canal Zone. No. 106507 United States National Museum. Female. Total length $53 \mathrm{~mm}$., standard length $42 \mathrm{~mm}$.

Description of the type.-Head 4.1; depth 8.2; D. VI-I, 10; A. I, 9 ; P. 18; scales too small to enumerate accurately, probably about 125 in a lateral series. 
Body very slender, compressed posteriorly; depth of caudal peduncle 3.4 in head; head depressed, fully an eye's diameter wider than deep; snout moderately long 5.1 in head; eye moderate, scarcely directed upward, 5.8; interorbital 9.3; mouth large, oblique, lower jaw projecting; maxillary reaching middle of eye, 3.3 in head; gill openings restricted, not quite extending forward to margin of preopercle; scales somewhat reduced in size anteriorly, scarcely embedded, all cycloid; head with many rows of pores about the eyes; dorsal fins far apart, none of the spines of the first reaching the second if deflexed; origin of the second dorsal almost equidistant from posterior margin of the eye and base of caudal; caudal fin somewhat pointed, the longest rays equal to length of head, with 11 rudimentary rays above and 11 below, extending forward on the caudal peduncle a distance about equal to depth of peduncle; anal similar to second dorsal, its origin scarcely an eye's diameter posterior to origin of second dorsal; ventrals small, 2 in head; pectorals much larger, pointed, reaching nearly half their length beyond tips of ventrals, 1.5 in head.

Color of preserved specimen light brown, pale underneath; a rather conspicuous black blotch behind upper part of gill opening; sides anteriorly with suggestions of pale cross-lines. Dorsal and caudal fins somewhat darker brown than the back, without definite dark spots; anal fin paler brown than dorsals and caudal, also unspotted; ventrals and pectorals pale, with brownish points.

A single paratype, a male, $55 \mathrm{~mm}$. long, taken in the mouth of a brackish creek at Puerto Pilón (Atlantic side) is at hand. The following proportions and counts are based on this specimen: Head 3.5 ; depth 6.5 ; D. VI-I, 10 ; A. I, 9 ; P. 17; scales too small and irregular to enumerate, probably about 125 in lateral series. Snout 5.3 in head; eye 6 ; interorbital 9.3 ; maxillary 3 ; caudal peduncle 3.2 . The paratype, being a male, has higher dorsal and anal fins than the holotype, and the caudal fin is longer and more sharply pointed, the longest rays a little longer than the head. This specimen, including the fins, is much darker brown than the holotype, and the vertical fins (especially the caudal) have definite black spots. No dark blotch is evident, however, behind the upper part of the gill opening as in the holotype.

The two small specimens of this species are insufficient to determine the exact difference between it and clarki. Apparently the second dorsal and anal fins are a little shorter in shropshirei, each having 1 to 3 fewer rays, as shown in the descriptions. Furthermore, 
the scales, though they cannot be enumerated definitely, apparently are larger in shropshirei. It is judged from the fully developed fins (those of the male being somewhat produced) and anal flap that the small specimens of shropshirei are sexually fully mature. A specimen of clarki of somewhat similar size $(63 \mathrm{~mm}$. long) at hand has this secondary sexual character little developed and so imperfectly that it is impossible to determine the sex by its shape. This difference in development suggests that the Atlantic coast species, as in Eleotris, reaches maturity at a smaller size, and also that it probably attains a smaller size. E. shropshirei apparently has a larger eye and longer pectoral and ventral fins, as shown in figures 12 and 13.

As it is not evident from the material at hand that the species of this genus enter strictly fresh water, it apparently may be assumed

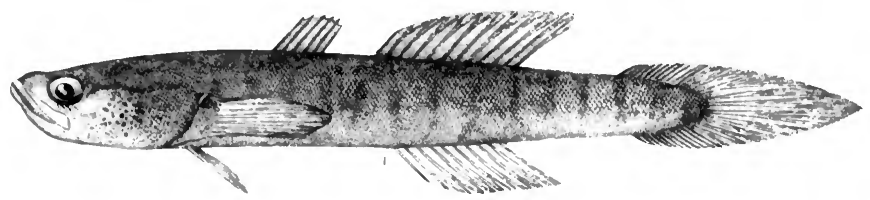

FIG. 13. Euleptoeleotris shropshirei sp. nov. Type, female, $53 \mathrm{~mm}$. long. (From drawing by Andrew Pizzini.)

that no crossing over from one side to the other through the Canal has taken place.

This species is named in honor of J. B. Shropshire, supervisor of malaria control for the United States Army in Panama, who took the holotype in the dry dock at Mount Hope, when it was pumped out, and who assisted the writer in many other ways while he was working in Panama in 1937.

\section{Hemieleotris latifasciatus (Meek and Hildebrand).}

Eleotris latifasciatus Meek and Hildebrand, Field Mus. Nat. Hist., Zool. Ser., 10, p. 68, 1912-Rio Cárdenas, Pacific slope, Panama.

Hemieleotris latifasciatus Meek and Hildebrand, Field Mus. Nat. Hist., Zool. Ser., 10, p. 365, pl. 32, 1916.

A single specimen, $65 \mathrm{~mm}$. long, was taken in the Rio Pacorá (Pacific slope).

This species is reported from the Pacific slope from Costa Rica and Panama to southern Colombia. 
Awaous Cuvier and Valenciennes.

Awaous Cuvier and Valenciennes, Hist. Nat. Poiss., 12, p. 97 (quarto ed., p. 73), 1837; Steindachner, Sitzber. Akad. Wiss., Wien, 42, p. 289 (1860?); Ginsburg, Proc. U. S. Nat. Mus., 82, art. 20, pp. 20-21, 1933.

As shown by Ginsburg, the name Awaous dates from Cuvier and Valenciennes, 1837, rather than from Steindachner, 1860 or 1861, and has clear priority over Chonophorus Poey, 1860.

Awaous taiasica (Lichtenstein).

Gobius taiasica Lichtenstein, Abhandl. Preuss. Akad. Wiss., Berlin, 1822, p. 273-Brazil.

Awaous taiasica Meek and Hildebrand, Field Mus. Nat. Hist., Zool. Ser., 10, p. 366, 1916.

This fresh-water goby is represented in the recent collections by four specimens, 57 to $85 \mathrm{~mm}$. long, all taken by J. B. Shropshire in a fresh-water stream at Fort Sherman (Toro Point), where Meek and Hildebrand did not obtain it in 1911 and 1912, although they collected there. The specimens conform well to the description of specimens from the Chagres Basin by Meek and Hildebrand (1916, p. 367). Behre '(1928, p. 311) recorded it from creeks flowing into Almirante Bay, western Panama. The probable range of this species was given by us (1916, p. 368) as extending on the Atlantic slope from Mexico to Brazil. Eigenmann (1922, p. 216) since has shown that another species inhabits the Atlantic slope of Colombia (Atrato and Magdalena basins), which he named A. decemlineatus. He did not state whether taiasica also occurs there. If not, the Panama fish probably also is different from the Brazilian form on which taiasica is based. If that be true, which cannot now be determined for want of time and material, the Panama species, unless one of the several supposed synonyms of taiascia based on Central American, Mexican, and West Indian specimens is available, would be without a name.

Awaous transandeanus (Günther).

Gobius transandeanus Günther, Cat. Fish. Brit. Mus., 3, p. 62, 1861-western Ecuador.

Awaous transandeanus Meek and Hildebrand, Field Mus. Nat. Hist., Zool. Ser., 10, p. 368, 1916.

This species is represented by five specimens, ranging in length from 17 to $51 \mathrm{~mm}$., all taken in small coastal streams between Campaña and La Venta. Juveniles were common on sandy bottom in very shallow quiet water in a small stream near La Venta, but they were so small and slender that they mostly escaped through the meshes of a bobbinet seine. 
The differences between this and the Atlantic slope form seem to be correctly set forth by Meek and Hildebrand (1916, p. 366). Dark crossbars present in this species, but not in taiasica, are especially prominent in juveniles.

Eigenmann (1922, p. 216) gave the range of this species as extending southward on the Pacific slope to Colombia and Ecuador. Northward it ranges to Mexico.

\section{Sicydium salvini Grant.}

Sicydium salvini Grant, Proc. Zool. Soc. Lond., 1884, p. 159, pl. 12, fig. 2Panama; Meek and Hildebrand, Field Mus. Nat. Hist., Zool. Ser., 10, p. $369,1916$.

This species is not in the present collection. It is known from both slopes of central Panama, and ranges to the Magdalena Basin in Colombia and to western Ecuador.

\section{Sicydium pittieri Regan.}

Sicydium pittieri Regan, Ann. Mag. Nat. Hist., (7), 19, p. 260, 1907-Rio Grande de Térraba, Costa Rica.

This species is included in the Panama fauna on the basis of a record by Behre $(1928$, p. 312$)$, who secured six specimens in a small stream tributary to the Rio Chiriquí del Tire (Pacific slope), western Panama.

This fish apparently differs chiefly from Sicydium salvini, the only other species recorded from Panama, in the naked area on the median part of the belly. However, Eigenmann (1922, p. 214) found a naked area, also, in small specimens of salvini. The fin-ray and scale counts of the two species seem to agree.

The range, as far as known, is Costa Rica and western Panama; possibly on the Pacific slope only.

\section{REFERENCES}

BEHRE, ELLINOR H.

1928. A List of the Fresh Water Fishes of Western Panama between Long.

$81^{\circ} 45^{\prime}$ and $83^{\circ} 15^{\prime}$ W. Ann. Carnegie Mus., 18, pp. 305-328, 2 pls.

BREDER, C. M., JR.

1925. Notes on Fishes from Three Panama Localities, Gatun Spillway, Rio Tapia, and Caledonia Bay. Zoologica, 4, No. 4, pp. 137-158, figs. 33-38.

1925. New Loricariate, Characin and Poeciliid Fishes from the Rio Chucunaque, Panama. Amer. Mus. Nat. Hist. Nov., No. 180, 9 pp., 7 figs.

1927. The Fishes of the Rio Chucunaque Drainage, Eastern Panama. Bull. Amer. Mus. Nat. Hist., 57, pp. 91-176, 10 figs., 5 pls.

1933. The Fishes of Barro Colorado, Gatun Lake, Panama. Zoologica, 9, No. 16 , pp. 565-572, fig. 385 . 


\section{Field Museum of Natural History-Zoology, Vol. XXII}

EigenmanN, Carl H.

1917-1929. The American Characidae. Mem. Mus. Comp. Zool., 43, pts. $1-5,558$ pp., 94 pls.

1920. The Fresh-Water Fishes of Panama East of Longitude $80^{\circ} \mathrm{W}$. Indiana Univ. Studies, No. 47A, pp. 3-19.

1922. The Fishes of Western South America. Part I- The Fresh-Water Fishes of Northwestern South America, including Colombia, Panama and the Pacific slopes of Ecuador and Peru, together with an Appendix upon the Fishes of the Rio Meta in Colombia. Mem. Carnegie Mus., 9, 350 pp., 38 pls.

Evermann, Barton W. and Goldsborough, Edmund L.

1909. Notes on Some Fishes from the Canal Zone. Proc. Biol. Soc. Wash., 22, pp. 95-104, 3 figs.

FOWLER, HENRY W.

1916. Cold-blooded Vertebrates from Costa Rica and the Canal Zone. Proc. Acad. Nat. Sci. Phila., 1916, pp. 389-414, 4 figs.

Gilbert, Charles H. and Starks, Edwin C.

1904. The Fishes of Panama Bay. Mem. Calif. Acad. Sci., 4, 304 pp., 33 pls., 62 figs.

\section{GÜNTHER, ALBERT}

1866. On the Fishes of the States of Central America; founded upon specimens collected in the fresh and marine waters of various parts of that country by Messrs. Salvin, Godman and Capt. J. M. Dow. Proc. Zool. Soc. Lond., 1866, pp. $600-604,25$ pls.

1868. An Account of the Fishes of the States of Central America; based on collections made by Capt. J. M. Dow, F. Godman, Esq., and O. Salvin, Esq. Trans. Zool. Soc. Lond., 6, pp. 377-494, map and pls. 64-87.

Hildebrand, Samuel F.

1925. Fishes of the Republic of El Salvador, Central America. Bull. U. S. Bur. Fish., 41, pp. 237-287, 20 figs.

1928. On a Small Collection of Fishes from Chiriqui, Panama. Copeia, 1928, No. 168 , pp. $81-84$.

1930. Notes on a Collection of Fishes from Costa Rica. Copeia, 1930, No. 1, pp. 1-9.

1935. An Annotated List of the Fishes of the Fresh Waters of Puerto Rico. Copeia, 1935, No. 2, pp. 49-56.

1935. Trout Fishing in the Tropics, Rainbow Trout in the Rio Chiriqui Viejo, Panama. Bull. Pan-American Union, Oct., 1935, pp. 763-767.

1937. The Tarpon in the Panama Canal. Scientific Monthly, 44, pp. 239-248, 4 figs.

Hildebrand, Samuel F. and Cable, louella E.

1938. Further Notes on the Development and Life History of Some Teleosts at Beaufort, North Carolina. Bull. U. S. Bur. Fish., 48, No. 24, pp. 505-642, 159 figs.

HuBBS, CARL L.

1924. Studies of the Fishes of the Order Cyprinodontes. Misc. Pub. Mus. Zool., Univ. Mich., No. 13, 31 pp., 4 pls.

1926. Studies of the Fishes of the Order Cyprinodontes. Misc. Pub. Mus. Zool., Univ. Mich., No. 16, 87 pp., 4 pls.

1935. Occ. Pap. Mus. Zool., Univ. Mich., No. 302, 3 pp., 1 pl.

Hubbs, Carl L. and Hubbs, Laura C.

1932. Apparent Parthenogenesis in Nature, in a Form of Fish of Hybrid Origin. Science, 76, No. 1983, pp. 628-630. 
Jordan, David Starr, Evermann, Barton W. and Clark, Howard W. 1930. Check List of the Fishes and Fishlike Vertebrates of North and Middle America North of the Northern Boundary of Venezuela and Colombia. Rept. U. S. Comm. Fish., 1928, pt. 2, 670 pp.

Le Prince, Joseph A. and Orenstein, A. J.

1916. Mosquito Control in Panama. 335 pp., illus. G. P. Putnam's Sons.

MeEk, Seth Eugene

1907. Notes on Fresh-Water Fishes from Mexico and Central America. Field Mus. Nat. Hist., Zool. Ser., 7, pp. 133-157.

1914. An Annotated List of Fishes Known to Occur in the Fresh Waters of Costa Rica. Field Mus. Nat. Hist., Zool. Ser., 10, pp. 101-134.

Meek, Seth E. and Hildebrand, Samuel F.

1916. The Fishes of the Fresh Waters of Panama. Field Mus. Nat. Hist., Zool. Ser., 10, pp. 217-374, pls. 6-32.

1923. The Marine Fishes of Panama. Field Mus. Nat. Hist., Zool. Ser., 15 , pt. 1,330 pp., 24 pls.

Myers, George S.

1927. An Analysis of the Genera of Neotropical Killifishes Allied to Rivulus. Ann. Mag. Nat. Hist., (9), 19, pp. 115-129.

REgAN, C. TATE

1905. A Revision of the Fishes of the American Cichlid Genus Cichlasoma and the Allied Genera. Ann. Mag. Nat. Hist., (7), 16, pp. 60-77, 225-243, $316-340,433-445$.

1906-1908. Biologia Centrali-Americana. Pisces, 203 pp., 26 pls.

1908. A Collection of Freshwater Fishes made by Mr. C. F. Underwood in Costa Rica. Ann. Mag. Nat. Hist., (8), 2, pp. 455-464.

1911. The Classification of the Teleostean Fishes of the Order Ostariophysi. Part 2-Siluroidea. Ann. Mag. Nat. Hist., (8), 8, pp. 553-577, 3 figs.

1913. A Revision of the Cyprinodont Fishes of the subfamily Poeciliinae. Proc. Zool. Soc. Lond., 1913, pp. 977-1018, 3 pls., 6 figs.

\section{Steindachner, Franz}

1879. Beiträge zur Kenntniss der Flussfische Südamerikas. Denkschr. Akad. Wiss., Wien, 41, pp. 151-172, 4 pls.

1880. Zur Fisch-Fauna des Cauca und der Flüsse bei Guayaquil. Denkschr. Akad. Wiss., Wien, 42, pp. 55-104, 9 pls. 






